Feasibility Study for the United Nuclear Corporation Disposal Site at the Oak Ridge Y-12 Plant, Oak Ridge, Tennessee 


\title{
Feasibility Study for the United Nuclear Corporation Disposal Site at the Oak Ridge Y-12 Plant, Oak Ridge, Tennessee
}

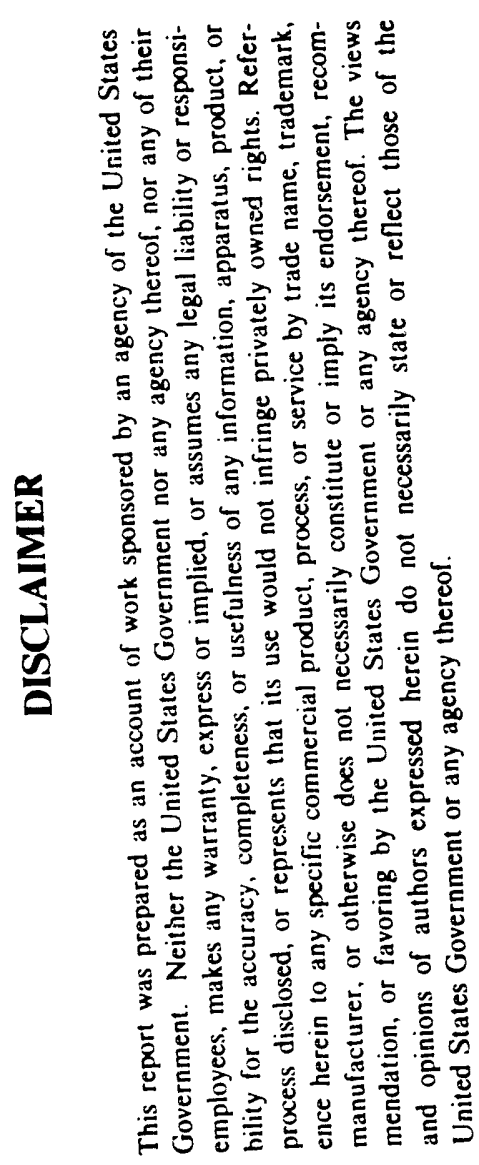

\author{
Environmental Restoration Division \\ P.O. Box 2003 \\ Oak Ridge, Tennessee 37831-7256
}

Date Issued-February 1991

\author{
Prepared by \\ Science Applications International Corporation \\ Oak Ridge, Tennessee \\ under subcontract 95Y-VK168C \\ Prepared for \\ U.S. Department of Energy
}

Office of Environmental Restoration and Waste Management under budget and reporting code EW 20

\section{MARTIN MARIETTA ENERGY SYSTEMS, INC.}

managing the

Oak Ridge National Laboratory

Oak Ridge K-25 Site

Oak Ridge Y-12 Plant

Paducah Gaseous Diffusion Plant

under contract DE-AC05-84OR21400

and the

Portsmouth Gaseous Diffusion Plant

under contract DE-AC05-76OR00001

for the

U.S. DEPARTMENT OF ENERGY

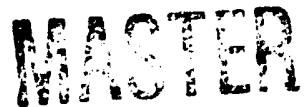




\section{CONTENTS}

FIGURES $\ldots \ldots \ldots \ldots \ldots \ldots \ldots \ldots \ldots \ldots \ldots \ldots \ldots \ldots \ldots \ldots \ldots \ldots \ldots \ldots$

TABLES $\ldots \ldots \ldots \ldots \ldots \ldots \ldots \ldots \ldots \ldots \ldots \ldots \ldots \ldots \ldots \ldots \ldots$

ACRONYMS AND INITIALISMS $\ldots \ldots \ldots \ldots \ldots \ldots \ldots \ldots \ldots$

EXECUTIVE SUMMARY $\ldots \ldots \ldots \ldots \ldots \ldots \ldots \ldots \ldots \ldots \ldots \ldots \ldots$

1. INTRODUCTION $\ldots \ldots \ldots \ldots \ldots \ldots \ldots \ldots \ldots \ldots \ldots \ldots$

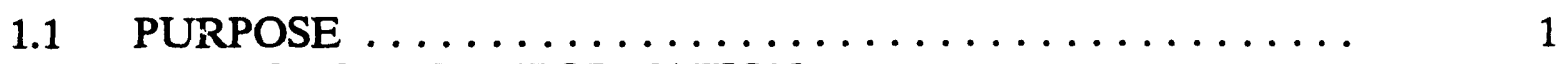

1.2 BACKGROUND INFORMATION $\ldots \ldots \ldots \ldots \ldots \ldots \ldots \ldots$

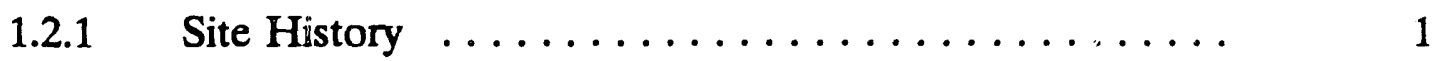

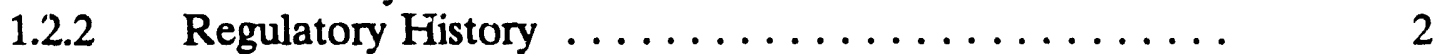

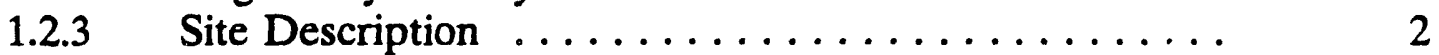

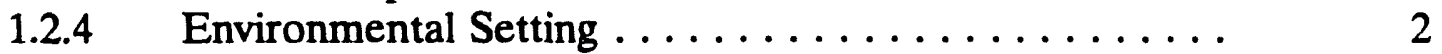

1.2.4.1 Demography $\ldots \ldots \ldots \ldots \ldots \ldots \ldots \ldots \ldots . \ldots \ldots$

1.2.4.2 Land use ............... 4

1.2.4.3 Topography, drainage, and

1.2.4.4 Geology/soils . . . . . . . . . . . . . 5

1.2.4.5 Hydrogeology .............. 11

1.2.5 Summary of Remedial Investigation . . . . . . . . . 12

1.2.5.1 Drum and box disposal area ......... 12

1.2.5.2 Wooden boxes .................. 14

1.2.5.3 Drummed soils/sludges $\ldots \ldots \ldots \ldots \ldots \ldots . \ldots 14$

1.2.5.4 Adjacent soils ............... 18

1.2.5.5 Groundwater $\ldots \ldots \ldots \ldots \ldots \ldots \ldots \ldots$

1.2.5.6 Potential pathways to the

$1.3 \quad$ RISK ASSESSMENT $\ldots \ldots \ldots \ldots \ldots \ldots \ldots \ldots \ldots \ldots$

1.3.1 Selection of Contaminants of Concern ........... 29

1.3.2 Exposure Assessment ................. 29

1.3.2.1 Characterizing the exposure

setting ................ 29

1.3.2.2 Identifying exposure pathways ........ 30

1.3.2.3 Quantification of exposure ........ 30

90-008P/0191 


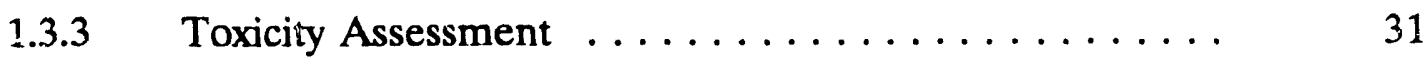

i3.3.1 Nitrate ................. 34

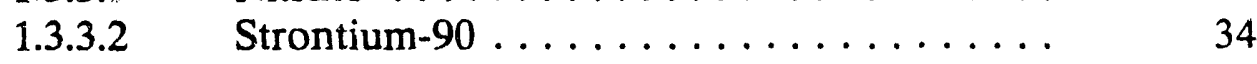

1.3.4 Risk Characterization $\ldots \ldots \ldots \ldots \ldots \ldots \ldots \ldots \ldots$

2. IDENTIFICATION OF RESPONSE ACTIONS AND

TECHNOLOGIES $\ldots \ldots \ldots \ldots \ldots \ldots \ldots \ldots \ldots \ldots \ldots \ldots \ldots \ldots \ldots$

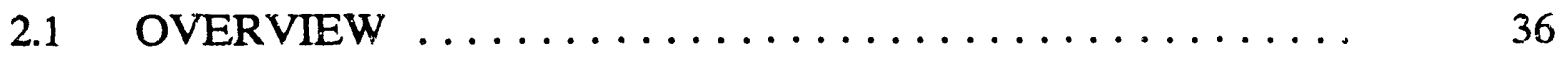

2.2 IDENTIFICATION OF MEDIA $\ldots \ldots \ldots \ldots \ldots \ldots \ldots \ldots . \quad 36$

2.3 APPLICABLE OR RELEVANT AND APPROPRIATE
REQUIREMENTS $\ldots \ldots \ldots \ldots \ldots \ldots \ldots \ldots \ldots \ldots \ldots$

2.3.1 Chemical-Specific ARARs . . . . . . . . . . 38

2.3.2 Location-Specific ARARs . . . . . . . . . . . . 40

2.3.3 Action-Specific ARARs ............... 40

2.3.3.1 On-site construction/excavation ....... 42

2.3.3.2 Surface water control $\ldots \ldots \ldots \ldots \ldots .42$

2.4 CONTAMINANTS OF INTEREST AND REMEDIAL

ACTION CRITERIA/GUIDANCE . . . . . . . . . . . . 50

2.5 SOURCE CONTROL OBJECTIVES $\ldots \ldots \ldots \ldots \ldots \ldots \ldots . . \ldots$

2.6 OTHER CONSIDERATIONS $\ldots \ldots \ldots \ldots \ldots \ldots \ldots \ldots \ldots$

2.6.1 Innovative Technologies $\ldots \ldots \ldots \ldots \ldots \ldots \ldots \ldots$

2.6.2 NEPA Considerations . . . . . . . . . . . . . 52

2.7 GENERAL RESPONSE ACTIONS $\ldots \ldots \ldots \ldots \ldots \ldots \ldots$

3. INITIAL SCREENING, EVALUATION, AND SELECTION

OF TECHNOLOGY TYPES AND PROCESS OPTIONS ........ 54

3.1 INITIAL SCREENING $\ldots \ldots \ldots \ldots \ldots \ldots \ldots \ldots \ldots \ldots$

3.1.1 No Action/Institutional Action . . . . . . . . . . . 60

3.1.2 Containment $\ldots \ldots \ldots \ldots \ldots \ldots \ldots \ldots \ldots \ldots$

3.1.3 Treatment $\ldots \ldots \ldots \ldots \ldots \ldots \ldots \ldots \ldots \ldots \ldots \ldots$

3.1.3.1 Waste processing $\ldots \ldots \ldots \ldots \ldots \ldots \ldots \quad 61$

3.1.3.2 Physical aqueous treatment .......... 61

3.1.3.3 Biological aqueous treatment $\ldots \ldots \ldots \ldots .62$

3.1.3.4 Chemical aqueous treatment $\ldots \ldots \ldots \ldots . \quad 62$

3.1.4 Disposal $\ldots \ldots \ldots \ldots \ldots \ldots \ldots \ldots \ldots \ldots, 62$

3.2 RESULTS OF SCREENING FOR SOURCE CONTROL .... 62 
3.3 EVALUATION OF PROCESS OPTIONS AND SELECTION OF REPRESENTATIVE PROCESSES $\ldots \ldots \ldots \ldots \ldots \ldots \ldots$

3.3.1 Evaluation Criteria $\ldots \ldots \ldots \ldots \ldots \ldots \ldots \ldots \ldots$

3.3.2 Selection Criteria .................... 64

3.3.3 Description of Selected Process Options
for Source Control Alternatives . . . . . . . . . . . .

3.3.3.1 No-action response $\ldots \ldots \ldots \ldots \ldots \ldots .64$

3.3.3.2 Containment response ............. 64

3.3.3.3 Treatment response $\ldots \ldots \ldots \ldots \ldots \ldots .69$

3.3.3.4 Disposal actions $\ldots \ldots \ldots \ldots \ldots \ldots \ldots .70$

3.4 DEVELOPMENT OF ALTERNATIVES $\ldots \ldots \ldots \ldots \ldots \ldots$

3.4.1 Alternative 1: No-Action Alternative .......... 70

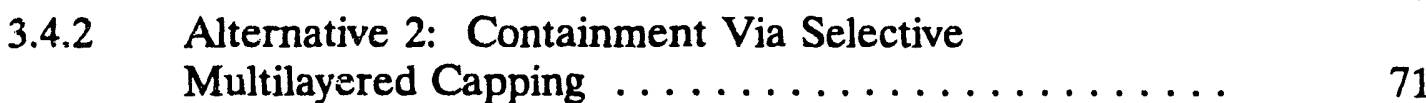

3.4.3 Alternative 3: Treatment Using a Combination of Solid Waste Processing; Physical, Chemical, and Biological Treatment of the Aqueous Waste; and Modified RCRA Cap ................... 71

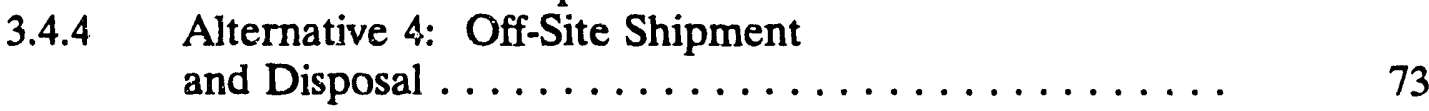

4. DETAILED ANALYSIS OF ALTERNATIVES ............ 74

4.1 NO-ACTION ALTERNATIVE $\ldots \ldots \ldots \ldots \ldots \ldots \ldots \ldots$

4.1.1 Short-Term Effectiveness $\ldots \ldots \ldots \ldots \ldots \ldots \ldots .75$

4.1.2 Long-Term Effectiveness and Permanence ..................... 75

4.1.3 $\begin{aligned} & \text { Reduction of Toxicity, Mobility, } \\ & \text { and Volume } \ldots \ldots \ldots \ldots \ldots \ldots \ldots \ldots \ldots \ldots \ldots\end{aligned}$

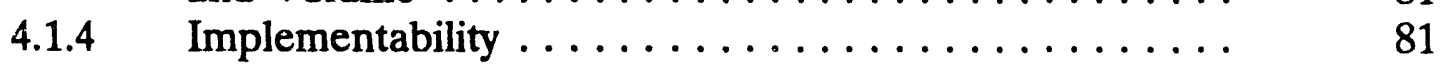

4.1.5 Cost Analysis ..................... 81

4.1.6 Compliance with ARARs $\ldots \ldots \ldots \ldots \ldots \ldots \ldots . \quad 81$

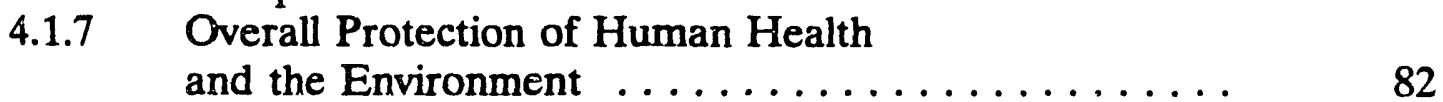

4.1.8 State Acceptance $\ldots \ldots \ldots \ldots \ldots \ldots \ldots \ldots \ldots \ldots \ldots$

4.1.9 Community Acceptance $\ldots \ldots \ldots \ldots \ldots \ldots \ldots . \quad 82$

4.2 MODIFIED RCRA CAP ALTERNATIVE .......... 82

4.2.1 Description of the Modified RCRA Cap ......... 84 
4.2.1.1 Low-permeability soil cap . . . . . . . . 84

4.2.1.2 Synthetic membranes ............ 85

4.2.1.3 Site-specific preparation

and construction $\ldots \ldots \ldots \ldots \ldots \ldots$

4.2.2 Short-Term Effectiveness . . . . . . . . . . . . 87

4.2.3 Long-Term Effectiveness and

Permanence ....................... 89

4.2.4 Reduction of Toxicity, Mobility,

and Volume ..................... 90

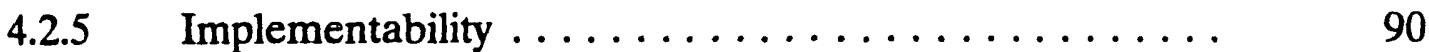

4.2.6 Cost Analysis ..................... 91

4.2.7 Compliance with ARARs . . . . . . . . . . . 92

4.2.8 Overall Protection of Human Health and the Environment $\ldots \ldots \ldots \ldots \ldots \ldots \ldots \ldots$

4.2.9 State Acceptance .................. 93

4.2.10 Community Acceptance $\ldots \ldots \ldots \ldots \ldots \ldots \ldots \ldots$

4.3 TREATMENT AND CAPPING ALTERNATIVE $\ldots \ldots \ldots \ldots .93$

4.3.1 Solid Waste Processing $\ldots \ldots \ldots \ldots \ldots \ldots \ldots \ldots$

4.3.2 Aqueous Waste Treatment $\ldots \ldots \ldots \ldots \ldots \ldots \ldots . \ldots \ldots$

4.3.3 Capping $\ldots \ldots \ldots \ldots \ldots \ldots \ldots \ldots \ldots \ldots \ldots \ldots \ldots$

4.3.4 Short-Term Effectiveness $\ldots \ldots \ldots \ldots \ldots \ldots \ldots \ldots . \ldots 9$

4.3.5 Long-term Effectiveness and 99

4.3.6 Reduction in Toxicity, Mobility,

4.3.7 Ease of Implementation $\ldots \ldots \ldots \ldots \ldots \ldots \ldots \ldots \ldots$

4.3.8 Cost Analysis . . . . . . . . . . . . . . . . . 101

4.3.9 Compliance with ARARs . . . . . . . . . . . . 101

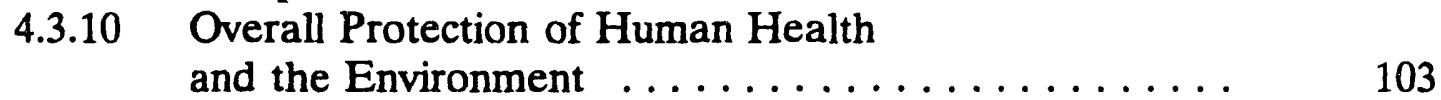

4.3.11 State Acceptance .................... 103

4.3.12 Community Acceptance $\ldots \ldots \ldots \ldots \ldots \ldots \ldots \ldots \ldots$

4.4 OFF-SITE DISPOSAL ALTERNATIVE $\ldots \ldots \ldots \ldots \ldots \ldots \ldots$

4.4.1 Short-Term Effectiveness $\ldots \ldots \ldots \ldots \ldots \ldots \ldots$

4.4.2 Long-Term Effectiveness . . . . . . . . . . . 106

4.4.3 Reduction of Toxicity, Mobility,

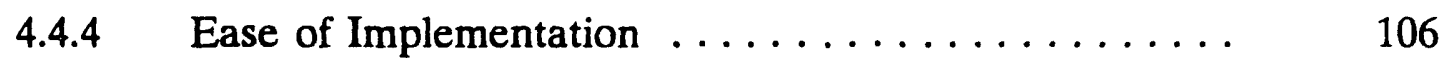

4.4.5 Cost Analysis .................. 107 
4.4.6 Compliance with ARARs . . . . . . . . . . 107

4.4.7 Overall Protection of Human Health and the Environment $\ldots \ldots \ldots \ldots \ldots \ldots$

4.4.8 State Acceptance .................. 108

4.4.9 Community Acceptance $\ldots \ldots \ldots \ldots \ldots \ldots \ldots$

4.5 SUMMARY AND COMPARISON OF ALTERNATIVES .... 108

4.5.1 Short-Term Effectiveness .............. 109

$\begin{array}{ll}\text { 4.5.2 Long-Term Effectiveness and } & \\ & \text { Permanence ..................... } 109\end{array}$

4.5.3 Reduction of Toxicity, Mobility,

4.5.4 Ease of Implementation $\ldots \ldots \ldots \ldots \ldots \ldots \ldots \ldots \ldots$

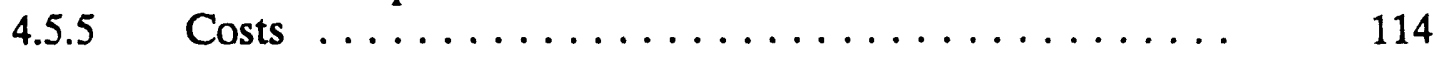

4.5.6 Compliance with ARARs . . . . . . . . . . . 114

4.5.7 Overall Protection of Human Health 115

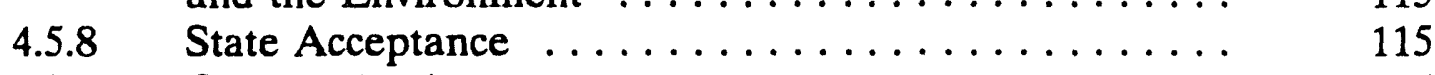

4.5.9 Community Acceptance $\ldots \ldots \ldots \ldots \ldots \ldots \ldots \ldots$

REFERENCES $\ldots \ldots \ldots \ldots \ldots \ldots \ldots \ldots \ldots \ldots \ldots \ldots \ldots \ldots \ldots \ldots$

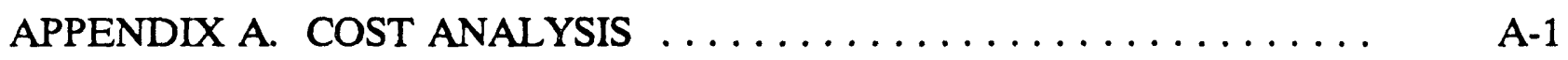




\section{FIGURES}

1. Location of UNC Disposal Site $\ldots \ldots \ldots \ldots \ldots \ldots \ldots \ldots$

2. Topographic map of the UNC Disposal Site vicinity $\ldots \ldots \ldots \ldots \ldots$

3. Surface drainage pattern in the immediate UNC

Disposal Site vicinity .................... 7

4. Drainage basin receiving UNC Disposal Site surface runoff $\ldots \ldots \ldots$

5. Generalized geologic map of the Y-12 Plant $\ldots \ldots \ldots \ldots \ldots \ldots$

6. Generalized geologic section through the Y-12 Plant ......................... 10

7. Well locations and water table map for the

UNC Disposal Site, second quarter, $1990 \ldots \ldots \ldots \ldots \ldots$

8. Proposed modified RCRA cap UNC Disposal Site $\ldots \ldots \ldots \ldots \ldots$

9. Schematic of solid waste processing and wastewater treatment of Alternative $3 \ldots \ldots \ldots \ldots \ldots \ldots \ldots$ 


\section{TABLES}

1. Summary of drum sampling - EP toxicity testing

for RCRA hazardous waste constituents

2. Summary of drum sampling - EP toxicity testing

for non-RCRA waste constituents ............... 16

3. Nitrate inventory $\ldots \ldots \ldots \ldots \ldots \ldots \ldots \ldots \ldots \ldots \ldots$

4. Representative results of area soil analyses . . . . . . . . . . . 19

5. Screening of groundwater samples from GW-203 to

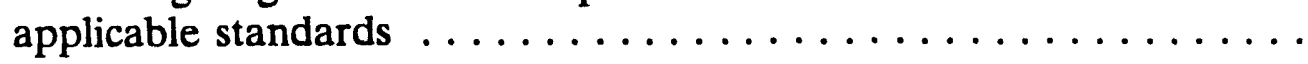

6. Screening of groundwater samples from GW-205 to

applicable standards $\ldots \ldots \ldots \ldots \ldots \ldots \ldots \ldots \ldots$

7. Screening of groundwater samples from GW-221 to

applicable standards $\ldots \ldots \ldots \ldots \ldots \ldots \ldots \ldots \ldots \ldots \ldots \ldots$

8. Screening of groundwater samples from Well 1090 to

applicable standards $\ldots \ldots \ldots \ldots \ldots \ldots \ldots \ldots \ldots \ldots$

9. Screening of groundwater samples from Well 1091 to

applicable standards $\ldots \ldots \ldots \ldots \ldots \ldots \ldots \ldots \ldots$

10. Background groundwater metal concentrations for

Chestnut Ridge ........................

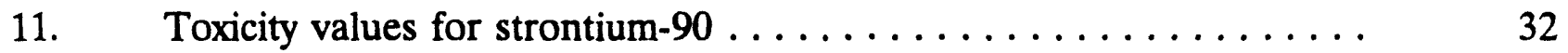

12. Toxicity information for nitrate $\ldots \ldots \ldots \ldots \ldots \ldots \ldots \ldots$

13. Potential location-specific applicable or relevant and appropriate requirements (ARARs) for the UNC Disposal Site

14. Action-specific applicable or relevant and appropriate (ARARs) for control/contaminant responses

15. Action-specific applicable or relevant and appropriate (ARARs) for treatment responses $\ldots \ldots \ldots \ldots \ldots$ 
16. Action-specific applicable or relevant and appropriate (ARARs) for disposal responses

17. UNC Disposal Site summary of remedial action objectives, general response actions, technology types, and process options for the development

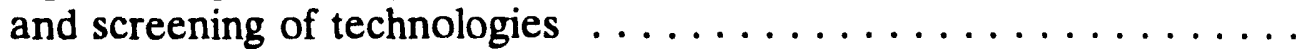

18. Initial screening of technologies and process options for source control alternatives $\ldots \ldots \ldots \ldots \ldots \ldots \ldots \ldots$

19. Evaluation of screened process options $\ldots \ldots \ldots \ldots \ldots \ldots \ldots$

20. Detailed analysis of Alternative 1: no action $\ldots \ldots \ldots \ldots \ldots$

21. Equations and variables for the groundwater

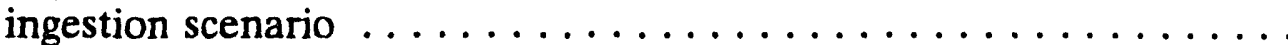

22. Evaluation of treatment alternatives for nitrate based

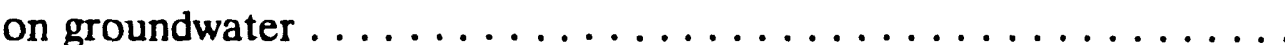

23. Evaluation of treatment alternative for strontium-90

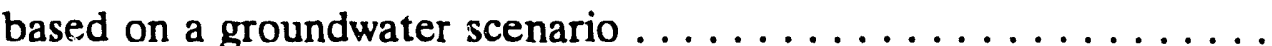

24. Detailed analysis of Alternative 2: modified RCRA cap . . . . . 88

25. Detailed analysis of Alternative 3: treatment and capping

26. Detailed analysis of Alternative 4: off-site disposal . . . . . . . . 105

27. Alternative assessment summary ................ 110

A.1 Alternative 1: no-action, capital cost $\ldots \ldots \ldots \ldots \ldots \ldots \ldots$

A.2 Alternative 1: no-action, basis of capital cost estimate ....... A-4

A.3 Alternative 1: no-action, annual operating costs $\ldots \ldots \ldots \ldots$ A-5

A.4 Alternative 1: no-action, cost analysis worksheet $\ldots \ldots \ldots \ldots$ A-6

A.5 Alternative 1: no-detion, sensitivity factors $\ldots \ldots \ldots \ldots \ldots \ldots$ A-7

A.6 Alternative 1: no-action, summary of sensitivity analysis $\ldots \ldots \ldots$ A-8 
A.7 Alternative 2: modified RCRA cap, capital cost $\ldots \ldots \ldots \ldots \ldots \ldots$ A-9

A.8 Alternative 2: modified RCRA cap, basis of direct cost estimate . . A-i0

A.9 Alternative 2: modified RCRA cap, annual operating costs . . . . . A-12

A.10 Alternative 2: modified RCRA, cap, cost analysis worksheet $\ldots \ldots \quad$ A-13

A.11 Alternative 2: modified RCRA cap, sensitivity factors . . . . . . A-14

A.12 Alternative 2: modified RCRA cap, summary of sensitivity analysis . A-15

A.13 Alternative 3: treatment and capping, capital cost $\ldots \ldots \ldots \ldots$ A-16

A.14 Alternative 3: treatment and capping, basis of capital cost estimate . A-17

A.15 Alternative 3: treatment and capping annual operating costs . . . . A-19

A.16 Alternative 3: treatment and capping, cost analysis worksheet . . . A A-20

A.17 Alternative 3: treatment and capping, sensitivity factors . . . . . . A-21

A.18 Alternative 3: treatment and capping, summary of sensitivity analysis A-22

A.19 Alternative 4: off-site disposal, capital cost $\ldots \ldots \ldots \ldots \ldots$ A-23

A.20 Alternative 4: off-site disposal, basis of capital cost estimate . . . . A-24

A.21 Alternative 4: off-site disposal, annual operating costs . . . . . . A-27

A.22 Alternative 4: off-site disposal, cost analysis worksheet $\ldots \ldots \ldots$ A-28

A.23 Alternative 4: off-site disposal, sensitivity factors . . . . . . . . A-29

A.24 Alternative 4. off-site disposal, summary of sensitivity analysis . . . . A-30 


\section{ACRONYMS AND INITLALISMS}

ACD

AEA

ALARA

ARAR

BCV

CERCLA

D\&D

DOE

DOE-ORO

DOT

E

EFPC

Energy Systems

EP

EPA

FFA

FS

HELP

HQ

LDRs

LL'V

MCL

MCLG

msl

NAAQS

NCP

NPDES

NPL

NRC

O\&M

ORNL

ORR

OSHA

PVC

QA/QC

RA

RCRA

RfD

RI

SARA
Analytical Chemistry Division

Atomic Energy Act

as low as reasonably achievable

applicable or relevant and appropriate requirement

Bear Creek Valley

Comprehensive Environmental Response, Compensation, and Liability

Act

decontaminate and decommission

U.S. Department of Energy

DOE Oak Ridge Operations

Department of Transportation

exposure

East Fork Poplar Creek

Martin Marietta Energy Systems, Inc.

extraction procedure

U.S. Environmental Protection Agency

Federal Facilities Agreement

Feasibility Study

Hydrologic Evaluation of Landfill Performance

hazard quotient

land disposal restrictions

low-level waste

maximum contaminant level

maximum contaminant level goal

mean sea level

National Ambient Air Quality Standard

National Oil and Hazardous Substances Contingency Plan

National Pollutant Discharge Elimination System

National Priorities List

Nuclear Regulatory Commission

operation and maintenance

Oak Ridge National Laboratory

Oak Ridge Reservation

Occupational Safety and Health Administration

polyvinyl chloride

quality assurance/quality control

reference area

Resource Conservation and Recovery Act

reference dose

remedial investigation

Superfund Amendments and Reauthorization Act 
TBC

TCA

TDHE

TSCA

UNC

WETF

WQC

to be considered

Tennessee Code Annotated

Tennessee Department of Health and Environment

Toxic Substance Control Act

United Nuclear Corporation

West End Treatment Facility

water quality criteria 


\section{EXECUTTVE SUMMARY}

In July 1990, the U.S. Environmental Protection Agency (EPA) directed the Department of Energy Oak Ridge Operations to comply with Comprehensive Environmental Response, Compensation, and Liability Act (CERCLA) requirements for the remediation of the United Nuclear Corporation (UNC) Disposal Site located at the Y-12 Plant, Oan Ridge, Tennessee. EPA, Waste Management Branch, had approved a closure plan in December 1989 for the UNC Disposal Site; however, the Y-12 Plant was placed on the National Priorities List (NPL) in December 1989, which required compliance with additional regulatory requirements. This feasibility study (FS) is to fully satisfy the National Oil and Hazardous Substances Contingency Plan (NCP) requirements for support of the selection of a remedial response for closure of the UNC Disposal Site.

The UNC Disposal Site is located near the crest of Chestnut Ridge, in the southern portion of the Y-12 Plant, in Oak Ridge, Tennessee. For two years the UNC Disposal Site accepted and disposed of waste from the decommissioning of a UNC uranium recovery facility in Wood River Junction, Rhode Island. Between June 1982 and November 1984, the UNC Disposal Site received 11,000 55-gal drums of sludge fixed in cement, 18,000 drums of contaminated soil, and 288 wooden boxes of contaminated building and process demolition materials. The UNC Disposal Site consists of a 1.3-acre excavation cut into the side of Chestnut Ridge. The UNC pit depth ranges from 25 to $30 \mathrm{ft}$ on the northern side to $<5 \mathrm{ft}$ on the southern side. The drums are stacked horizontally, $10 \mathrm{high}$, in a pyramid shape following the contour of the excavation. The wooden boxes are on the south side of the stacked drums and the entire waste site is covered in polyvinyl chloride sheeting. Many of the drums and boxes have deteriorated, allowing their contents to be exposed to the environment.

Concerns over the deteriorated condition of the drums and the potential migration of constituents from the drums prompted characterization of the UNC Disposal Site's waste, soil, and groundwater. Extraction procedure toxicity testing in 1985 on the drummed sludge and soil indicated the waste to be nonhazardous as defined by the Resource Conservation and Recovery Act (RCRA). Only nitrate and strontium-90 levels were above the Safe Drinking Water Act (SDWA) maximum contaminant criteria (MCL). A total nitrate and strontium-90 inveniory of 53 metric tons and $25 \mathrm{mCi}$, respectively, was estimated for the site. Soil and groundwater analysis indicated no elevated levels of contaminants, verifying that migration of contaminants had not occurred. Based on the estimated source invertory concentration, and on toxicological, physical, chemical, and environmental fate characteristics, nitrate and strontium-90 were deemed most likely to contribute to potential human health risk.

Groundwater was determined to be the only potential migration pathway for human exposure. Groundwater modeling predicted steady-state conditions after 13 years, resulting in a nitrate concentration of $193 \mathrm{mg} / \mathrm{L}$ in the groundwater. The maximum concentration for strontium- 90 predicted by modeling was $50 \mathrm{pCi} / \mathrm{L}$. These values were used to calculate the 
potential health risks from exposure. The hazard quotient for a groundwater nitrate concentratior of $193 \mathrm{mg} / \mathrm{L}$ is 3.4. Hazard quotients exceeding unity (1.0) indicate that exposure to that concentration may cause adverse noncarcinogenic health effects. Potential health effects for radionuclides are evaluated in terms of potential carcinogenic effects (the probability of an individual developing cancer over a lifetime of exposure to the potential carcinogen). The risk associated with the modeled groundwater exposure level of $50 \mathrm{pCi} / \mathrm{L}$ is $8.3 \mathrm{E}-5$, which is within the EPA range of concern (1.0E-4 to $1.0 \mathrm{E}-6)$.

Site investigation and modeling results indicated that the alternatives developed in this FS target only the waste material, and minimization of contaminant mobility and toxicity. No remedial actions are proposed for soil or groundwater because contamination of these media has not occurred. The alternatives developed, however, will ensure that contaminant levels in groundwater will not exceed maximum contaminant levels (MCLs) or maximum contaminant level goals (MCLGs) in the future and that any treatment discharges contain contaminants at levels as low as reasonably achievable. As mandated by CERCLA, a wide range of remedial alternatives were developed based on meeting applicable or relevant and appropriate requirements (ARARs) from federal and state regulations. In addition to establishing contaminant target levels for cleanup, CERCLA prescribes that remedial actions meet acceptable risk levels for human health.

This FS assembles a wide range of remedial technologies so the most appropriate actions could be selected to remediate potential contamination to below MCLs and/or to below the maximum level of acceptable risk. Technologies were initially screened based on site and waste characteristics. Technologies retained after this screening were further evaluated based on technical effectiveness, ease of implementation, and costs. Applicable technologies were then selected for alternative development. Following selection, the technologies were grouped to form alternatives. Four alternatives were developed for detailed and comparative analysis. These four alternatives include

- Alternative 1: No Action

The no-action alternative (as prescribed by CERCLA) is used as a baseline for evaluation of other remedial actions. No action involves leaving the disposal site undisturbed and implementing both water monitoring and site security. Alternative 1 does not reduce toxicity, mobility, or volume of contaminants; does not comply with ARARs; has a low degree of long-term effectiveness and performance; and has a low degree of overall protection of human health and the environment. Alternative 1 is feasible and easily implemented. The estimated total 30 -year present worth of the alternative is $\$ 483,000$.

- $\quad$ Alternative 2: Capping

This alternative consists of closing the UNC Disposal Site with a multilayer modified RCRA cap. Capping the site reduces the mobility of contaminants by covering and isolating the source and preventing both leachate production 
and potential contamination of the groundwater. Alternative 2 provides a high degree of long-term effectiveness and protection of human health and the environment. This alternative is technically and administratively feasible and complies with ARARs. The estimated total 30-year present worth of this alternative is $\$ 1,467,500$.

- $\quad$ Alternative 3: Treatment and Capping

This alternative involves 3 phases: solid waste processing, wastewater treatment, and capping of residual materials. The drummed sludge will be physically processed and the nitrates leached, resulting in a highly concentrated nitrate wastewater. The wastewater will be treated on-site using physical/chemical and biological denitrification processes. All residual materials, scrap material, and wastewater sludges will be placed back in the excavation and covered with a multilayer modified RCRA cap. Treatment reduces the volume and toxicity of nitrate, the contaminant of highest concentration in the contaminant source. Capping of the site reduces the mobility of the residual contaminants. Alternative 3 has low short-term effectiveness because of a long and involved implementation period. This alternative is technically and administratively feasible and complies with ARARs. This alternative provides a high degree of long-term effectiveness, but $a$ moderate degree of overall protection of human health and the environment. This alternative requires extensive engineering and design to implement, and the estimated total 30-year present worth of this alternative is $\$ 3,033,000$.

- $\quad$ Alternative 4: Off-site Disposal

This alternative involves handling and repackaging of the drums and debris, transport of the repackaged waste off-site, disposal at an approved facility, and return of the site to the preconstruction state. This alternative has a high degree of long-term effectiveness and a moderate degree of short-term effectiveness, resulting in a moderate degree of overall protection of human health and the environment. Alternative 4 is technically feasible and complies with ARARs. Toxicity, mobility, and volume of contaminants are eliminated because the contaminant source is removed from the site. The estimated total 4-year present worth of this alternative is $\$ 14,073,000$.

Based on the analysis, all alternatives except no action are expected to meet the minimal requirements for protection of human health by treating or removing the contaminated material or minimizing contaminant mobility. The alternatives, however, represent a wide range of technical and administrative requirements, ease of implementation, and cost. 


\section{UNITED NUCLEAR CORPORATION DISPOSAL SITE FEASIBILITY STUDY}

\section{INTRODUCTION}

\subsection{PJIRPOSE}

The purpose of this feasibility study (FS) is to identify, develop, and evaluate potential alternatives for remediation of the U.S. Department of Energy's (DOE) Oak Ridge Y-12 Plant United Nuclear Corporation (UNC) Disposal Site. This FS is conducted consistent with guidance provided by the Superfund Amendments and Reauthorization Act (SARA) of 1986 and the National Oil and Hazardous Substances Contingency Plan (NCP) promulgated July 16, 1982 (revised March 8, 1990). Alternatives developed as a result of this feasibility study form a basis from which a decision-making body may select a remedial action, which is recommended in a proposed plan and implemented by a record of decision (F.OD).

\subsection{BACKGROUND INFORMATION}

\subsubsection{Site History}

The Y-12 Plant, under the direction of DOE Oak Ridge Operations (ORO) Office, prepared a disposal site to accept waste from the decommissioned UNC uranium recovery facility. The UNC facility located in Wood River Junction, Rhode Island, was operated in conjunction with DOE defense program activities.

Operations were shut down in 1980, and UNC was required to decontaminate and decommission (D\&D) its facilities. The D\&D activity included excavating low-level radioactively contaminated soil and sludge from the associated ponds and trenches and removing the resultant low-level radioactive waste from the state of Rhode Island. The dismantling of the facility also resulted in demolition debris and scrap material being boxed and transported to the site.

The Oak Ridge UNC Disposal Site began receiving waste in June 1982, consisting primarily of 29,000 55-gal drums containing sludge fixed in concrete $(11,000)$, and contaminated soils $(18,000)$. In addition, the site received 288 boxes filled with contaminated equipment, hoods, pipes, building materials, and other demolition materials. No waste shipments have been received at this site since November 1984.

Waste characterization has confirmed the waste to be non-hazardous by Resource Conservation and Recovery Act (RCRA) standards; therefore, this site is not under the regulatory requirements for closure as a RCRA hazardous waste disposal site. 


\subsubsection{Regulatory History}

In December 1989, the U.S. Environmental Protection Agency (EPA) Waste Management Branch approver the Martin Marietta Energy Systems, Inc. (Energy Systems), plan for closure of the UNC Disposal Site (U.S. EPA 1989a). However, prior to the implementation of this closure, the Y-12 Plant was placed on the National Priorities List (NPL), which subsequently required the UNC Disposal Site to meet Comprehensive Environmental Response, Compensation, and Liability Act (CERCLA) guidelines. Characterizations of the UNC Disposal Site and associated waste that were performed to this point indicated no migration of waste constituents to adjacent soil or groundwater and identified the waste as nonhazardous as defined by RCRA.

EPA concluded that the UNC Disposal Site did not pose an imminent threat to public health and welfare and that remedial action was the appropriate option for the UNC Disposal Site (Scarborough 1990). EPA agreed that sufficient waste and site characterization had been performed to meet specific elements of the CERCLA remedial investigations; however, additional requirements were necessary to fulfill NCP requirements (Scarborough 1990). EPA identified several specific tasks required to support closure of the UNC Disposal Site. In general, the tasks required preparing an FS that met the CERCLA guidelines and provided documentation of community and regulatory review and the decision process (EPA 1988). EPA further concluded that a separaze remedial investigation (RI) report was not necessary and that the report Pathways Analysis for UNC Disposal Pit, Y-12 Plant could serve as the RI with minor supplements (i.e., Risk Assessment and recent groundwater quality data) (Scarborough 1990).

\subsubsection{Site Description}

The site selected for storage and disposal of UNC waste is near the crest of Chestnut Ridge in the southern portion of the Y-12 Plant (Fig. 1). Access roads for in-plant travel are located just north and south of the site. The waste pit was prepared on a 1.3-acre site by excavating $-22,000 \mathrm{yd}^{3}$ of soil frum the hill. A site grading plan, prepared in 1982 (Ref. C2E-109322), provides details of the excavation, drainage, and erosion control design.

Originally, the site terrain sloped to the southeast on a $10 \%$ grade. The maximum elevation difference was $\sim 40 \mathrm{ft}$ between the access road on the south and the crest of the ridge bordering on the north. The depth of the UNC pit ranges from $\sim 25$ to $30 \mathrm{ft}$ on the northern side to $5 \mathrm{ft}$ on the southern side, with the highest point of the site being the north and east walls. The north and east pit walls have now begun to erode, and the soil partially covers several drums positioned closest to the walls.

\subsubsection{Environmental Setting}

Elements of the environmental setting of the UNC Disposal Site having an impact on selection of an applicable alternative include demography; land use (past and potential); 




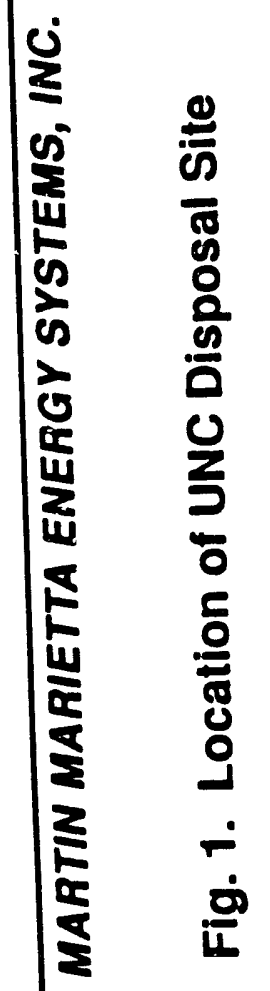

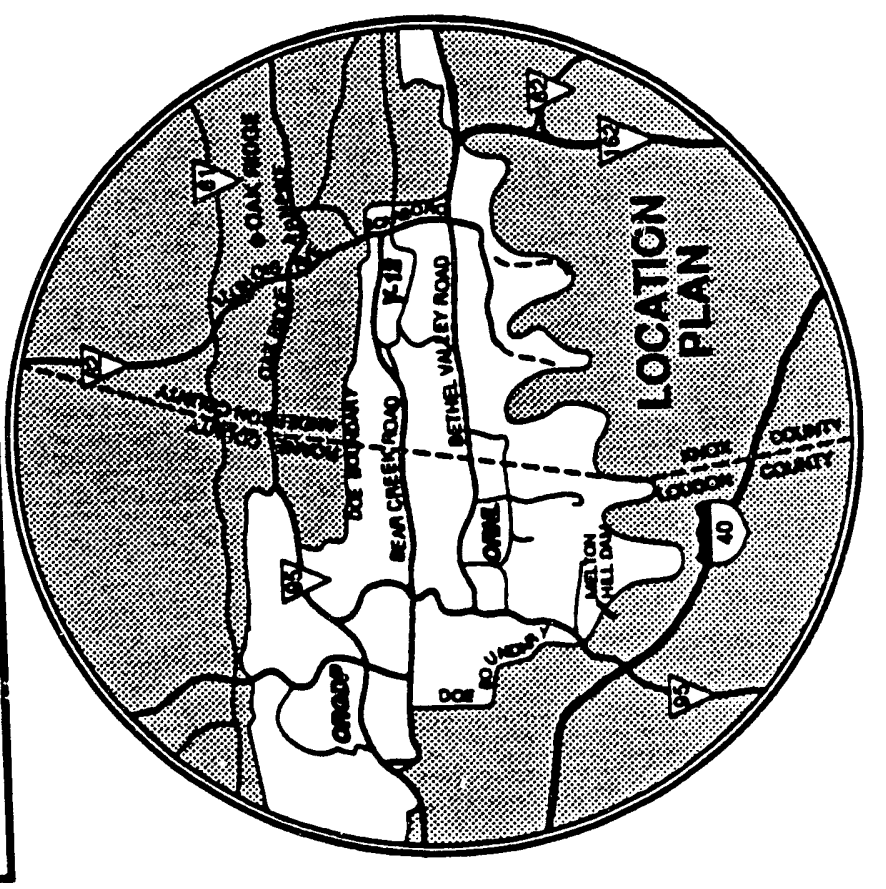


and surface topographic characteristics, including (1) surface waters and drainage patterns, (2) geology, and (3) hydrogeology. Each of these elements at the site is discussed in the following subsections.

\subsubsection{Demography}

The UNC Disposal Site is situated within the Oak Ridge Y-12 Plant on the DOE Oak Ridge Reservation (ORR) (Fig. 1). As such, no permanent residential population exists within $\sim 1$ mile of the site, which represents the distance to the closest reservation boundary. The population base of the Oak Ridge Y-12 Plant consists entirely of employees involved with plant operations. These personne are usually on-site for periods of $<10 \mathrm{~h} /$ day during the normal work week, Monday through Friday. Workers on rotating shifts norm: lly support plant operations during weekends and off-hours. The total number of Y-12 Plant employees as of January 1989 was 6835 (Cox 1990). The UNC Disposal Site is located in a relatively isolated portion of the limited area; therefore, only a small number of personnel infrequently work at, or adjacent to, the site. Strict access control prevents unauthorized entry into the limited area and reduces access to the UNC Disposal Site.

The closest off-site population base is the City of Oak Ridge adjoining the DOE Reservation to the north of the Y-12 Plant (Fig. 1). Current census statistics (1980) place the permanent population of Oak Ridge at $\sim 28,000$. The nearest point of approach between the Oak Ridge city limits and the UNC Disposal Site is $\sim 4500 \mathrm{ft}$ north-northwest. Restricted access to the Oak Ridge Y-12 Plant prevents unauthorized entry by the off-site population. The remaining area within 5 miles of the UNC Disposal Site that is not part of the ORR is predominantly rural residential population.

\subsubsection{Land use}

The UNC Disposal Site is located on land owned by the U.S. government and used for defense-related priduction facilities. The particular land use for the Y-12 Plant is predominantly indistrial. This has been the case since purchase of the ORR and construction of th 2 Oak Ridge Y-12 Plant in the early 1940s. Use of the Y-12 Plant grounds, other than for defense-related activities or by the general public, is unlikely due to institutional coritrol by the U.S. government.

The UNC Disposal Site has been used as a waste storage site since 1982; however, $\mathrm{n}$ s waste shipments have been received at this site since November 1984. Upon completion of remedial activities, no further uses are anticipated.

\subsubsection{Topography, drainage, and surface water}

The UNC Disposal Site is located in the Valley and Ridge Physiographic province. The topographic characteristics of this province consist of alternating linear ridges and valleys trending northeast-southwest. The UNC Disposal Site is located near the crest of 
Chestnut Ridge, which is a broad, flat-topped ridge bounding the Y-12 Plant grounds to the south. Bear Creek Valley (BCV) and Bethel Valley lie to the north and south of Chestnut Ridge, respectively. The ground surface at the UNC Disposal Site slopes $\sim 9 \%$ to the south. The peak site elevation is $\sim 1135 \mathrm{ft}$ above mean sea level (msl) at the north corner, with a minimum elevation of $-1105 \mathrm{ft}$ above msl at the south corner (Fig. 2). The amount of slope increases considerably immediately southeast and northwest of the site along the flanks of Chestnut Ridge.

Surface drainage across the UNC Disposal Site is predominantly controlled by surface grading and storm drains at the base of the drum storage area excavation and along access roads to the southeast and southwest. Natural topography primarily controls drainage along the northeast and northwest perimeter of the site. Figure 3 shows the surface drainage patterns in the vicinity of UNC Disposal Site.

The UNC Disposal Site is located immediately southeast of a watershed divide separating the East Fork Poplar Creek (EFPC) drainage basin to the northwest from watersheds of several small streams draining southeast, ultimately to the Clinch River (Melton Hill Lake). Surface runoff from the UNC Disposal Site is received by an unnamed tributary of McCoy Branch (Fig. 4). The watershed area of the unnamed stream is $\sim 300$ acres. This tributary also receives surface runoff from the Y-12 Plant Centralized Sanitary Landfill II site, approximately half of which is located in the subject watershed. McCoy Branch enters the Clinch River (Melton Hill Lake) almost immediately downstream of the confluence with the unnained tributary. No other watersheds receive runoff from the UNC Disposal Site.

\subsubsection{Geology/soils}

The bedrock units in the vicinity of the Y-12 Plant range from Cambrian to Ordovician age. These strata have been classified into groups and formations based on age, lithology, and fossil assemblages. From oldest to youngest, the bedrock units are the Rome Formation, Conasauga Group, and Knox Group. The Y-12 Plant area is underlain by Cambrian limestone, shale, and siltstone of the Conasauga Group. Sandy shale and siltstone of the Rome Formation underlie Pine Ridge to the north, whereas siliceous dolostone of the Knox Group forms Chestnut Ridge to the south (Figs. 5 and 6).

The Conasauga Group contains six formations composed of shale, siltstone, and limestones. These formations are, from oldest to youngest, the Pumpkin Valley Shale, Rutledge Limestone, Rogersville Shale, Maryville Limestone, Nolichucky Shale, and Maynardville Limestone (Fig. 5). The bedrock units are overlain by unconsolidated deposits of varying thickness (10-30 ft) and composition, which generally consist of man-made fill, alluvium, and in-situ weathered bedrock (residuum). 


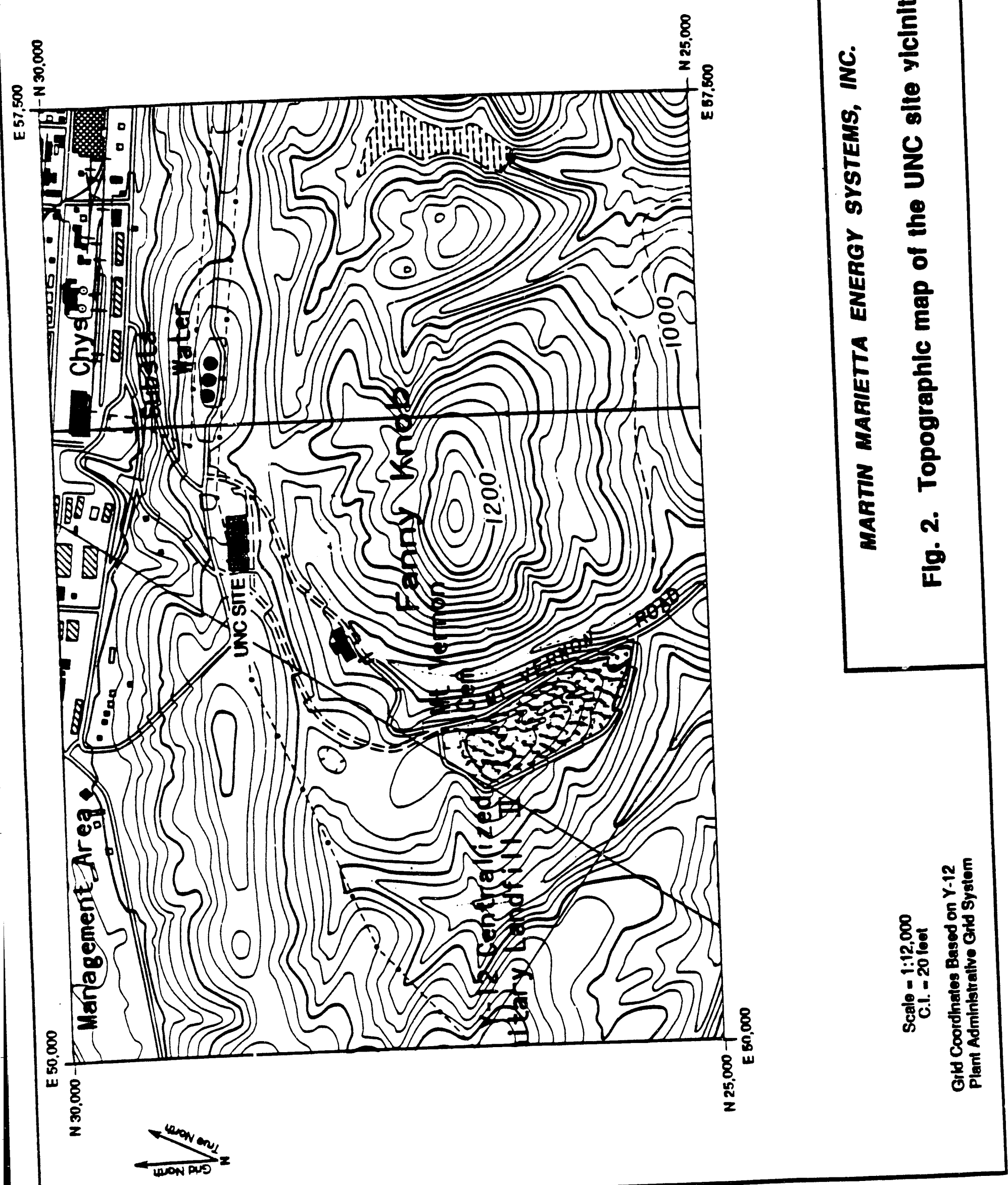




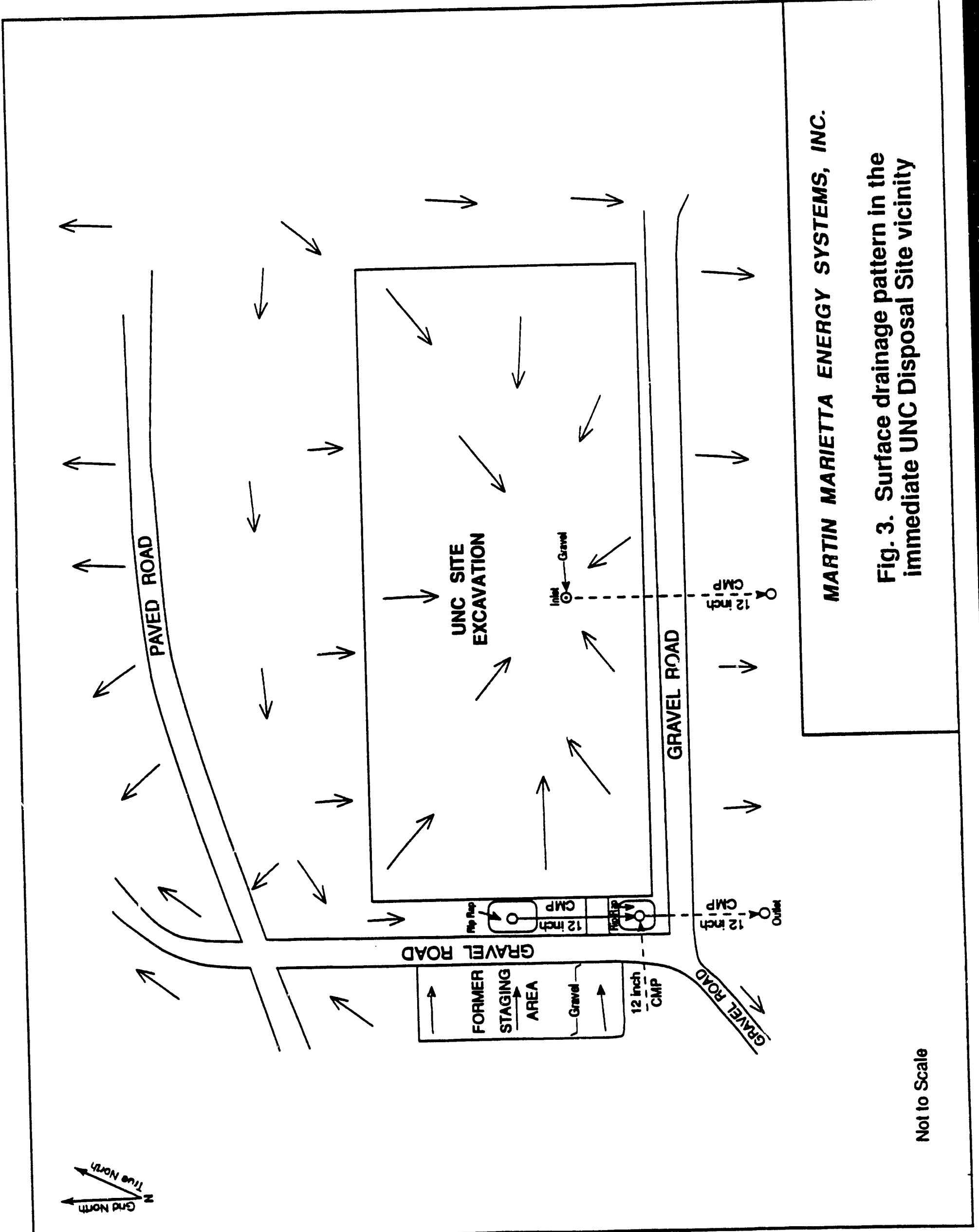




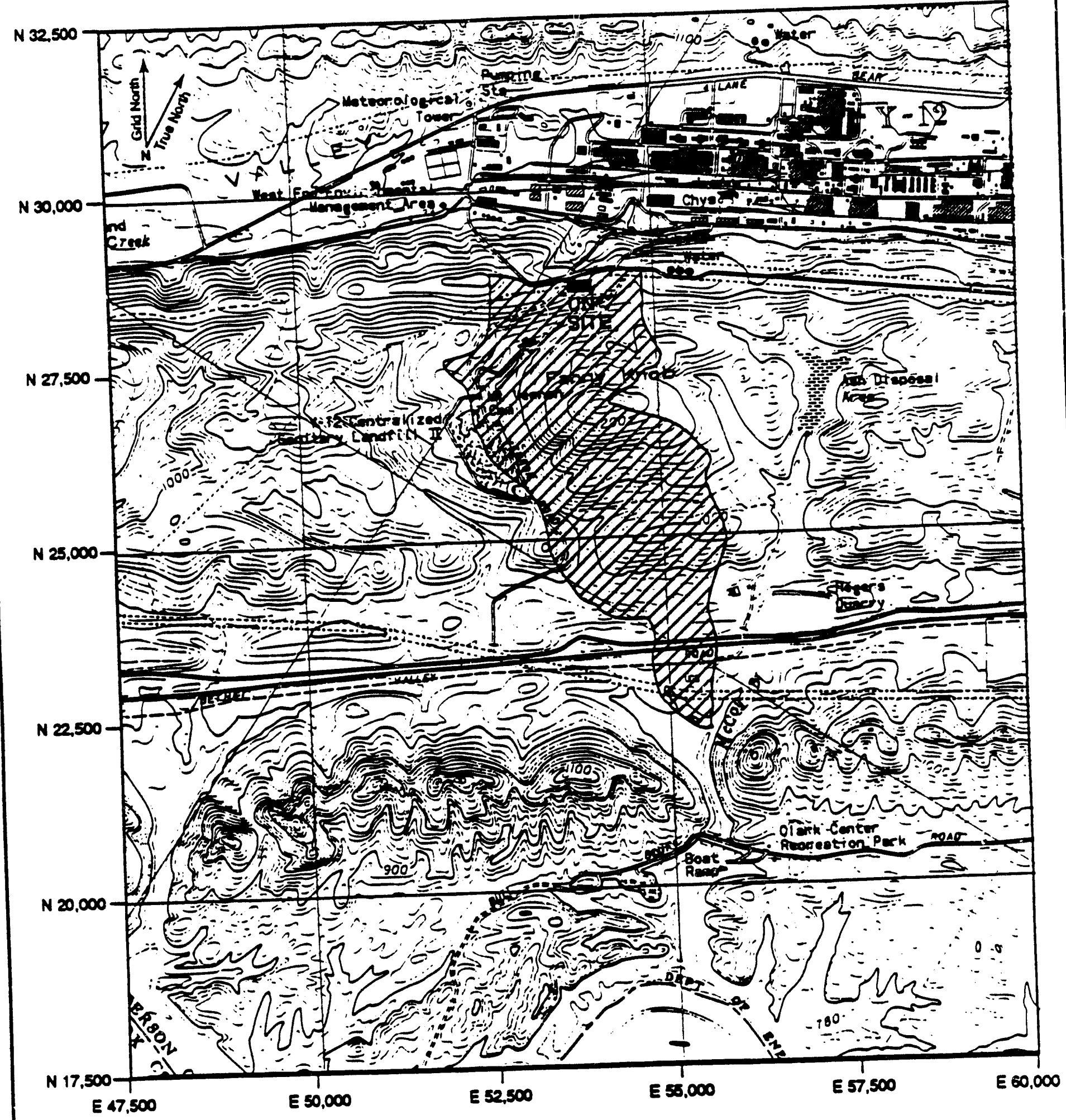

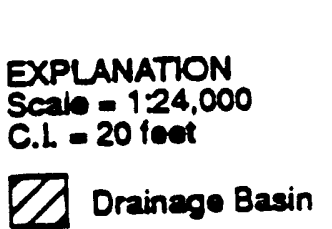

Grid Coordinates Besed on Y.12

Plam Administrative Grid System
MARTIN MARIETTA ENERGY SYSTEMS, INC.

Fig. 4. Drainage basin receiving UNC Disposal Site surface runoff 


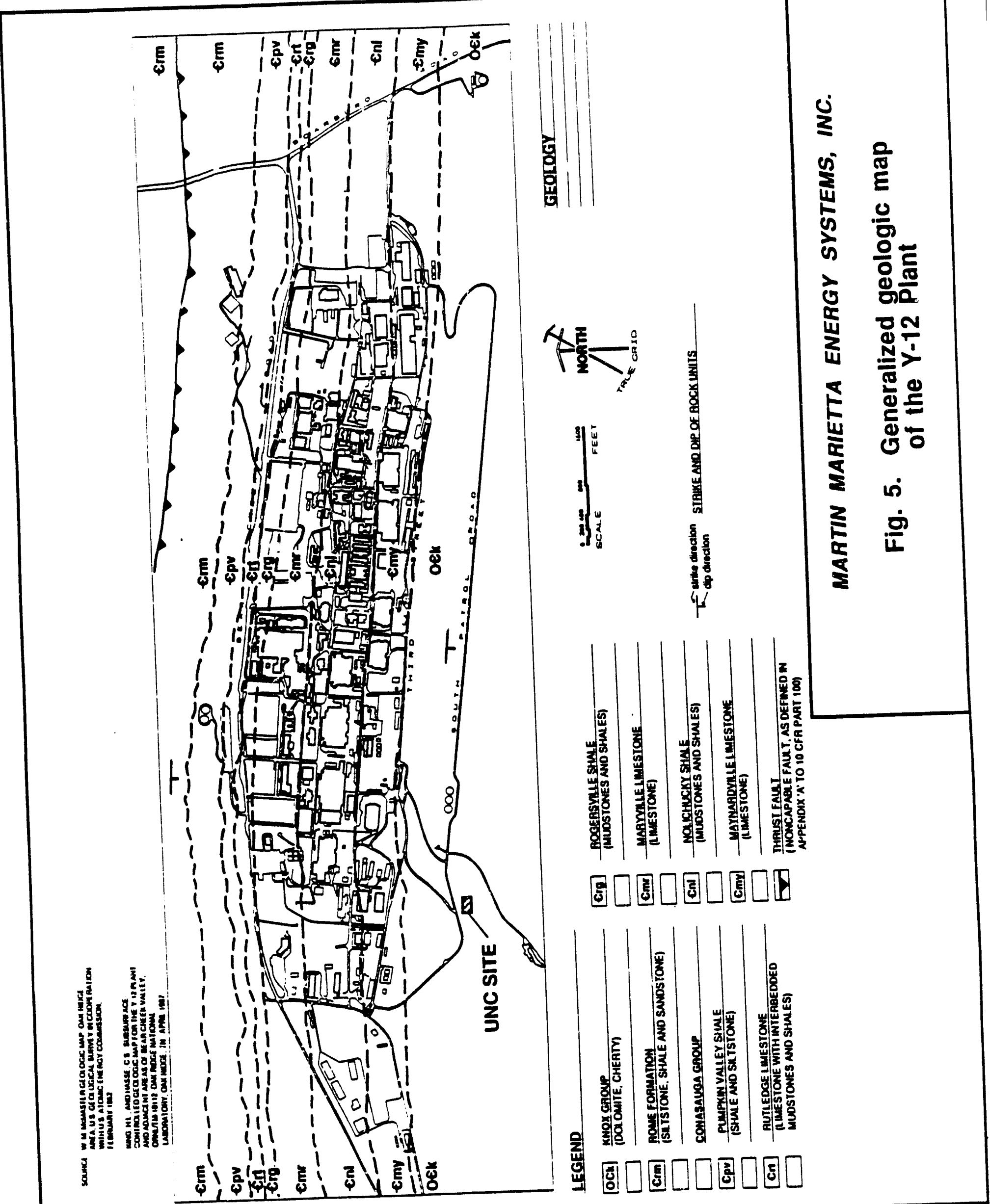



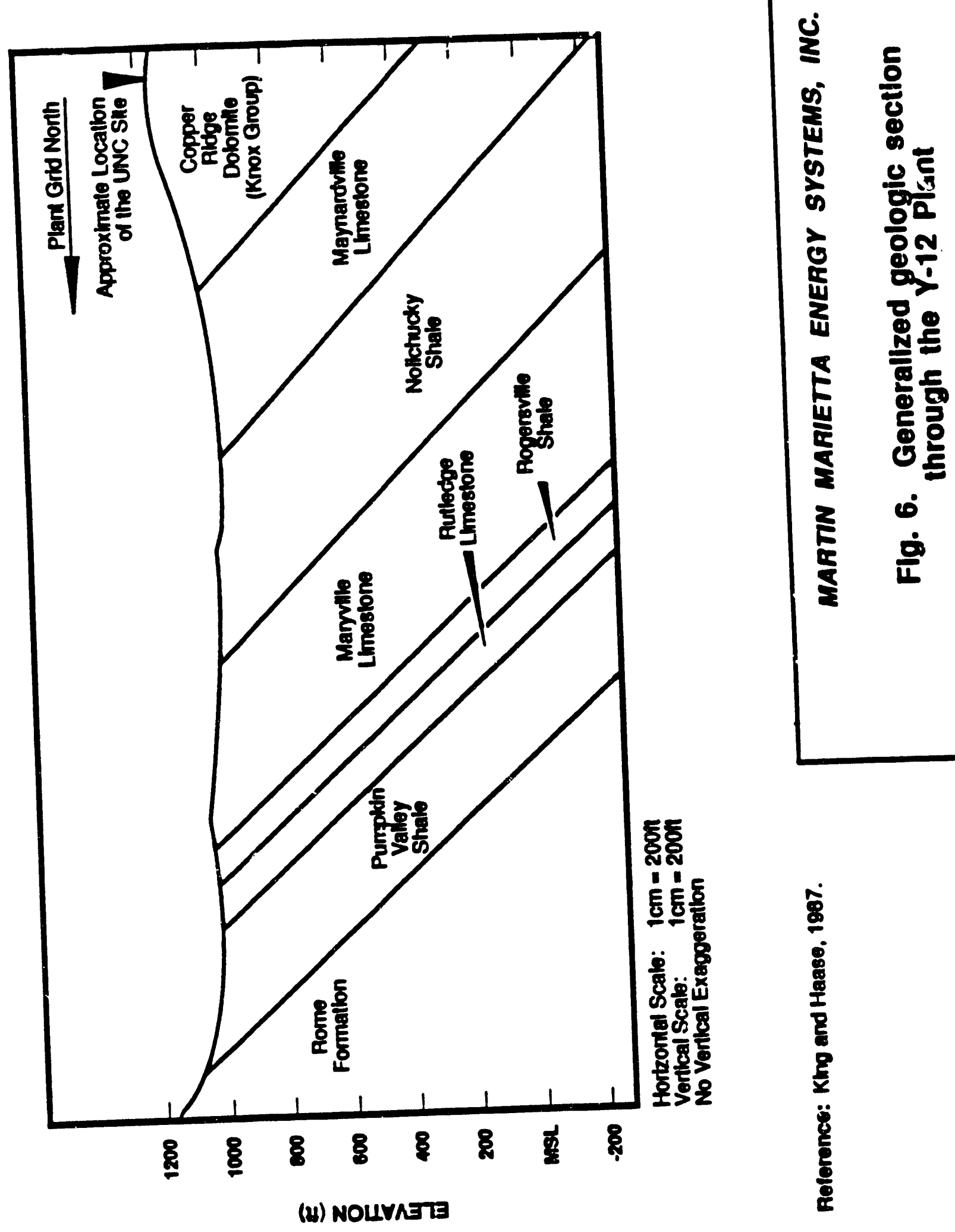
The Knox Group consists of four formations, which, from oldest to youngest, are the Copper Ridge Dolomite, Chepultepec Dolomite, Kingsport Formation, and Mascot Formation. Each of the formations consists of medium- to thick-bedded cherty dolostone. Chert content tends to increase up section.

The UNC Disposal Site is underlain by soil and residuum developed on top of the stratigraphically lowermost portion of the Copper Ridge Dolomite (Figs. 5 and 6). Moneymaker (1981) classified soils at the UNC Disposal Site as Fullerton soils, which are characterized by cherty silt loams at shallow depths to cherty clays at depths greater than $-3 \mathrm{ft}$. Residual chert fragment content, typically $>3 \mathrm{in}$., is between 2 and $18 \%$. Weston (1986) designated the UNC Disposal Site soils as CL (low plasticity clays and silty clays) to $\mathrm{CH}$ (highly plastic clays and sandy clays). Geotek (1982) drilled 5 boreholes within the UNC Disposal Site excavation limits before site construction. Soil/residuum thickness was determined to range from 54 to $83.5 \mathrm{ft}$ (Geotek 1982). Bailey et al. (1989) estimated that post-excavation soil/residuum thickness ranged from 40 to $60 \mathrm{ft}$.

Beneath the soil/residuum layer is a zone of weathered bedrock containing solution features, principally along bedding planes and fractures. Along portions of Chestnut Ridge near Oak Ridge National Laboratory (ORNL) this zone was found to range from zero to $>100 \mathrm{ft}$ in thickness (Ketelle and Huff 1984). Borings at the UNC Disposal Site prior to construction showed solution openings ranging in size from a few inches to $-3 \mathrm{ft}$. The thickness of the solution zone, however, was not determined, (Geotek 1982). No topographic expression of solution cavity collapse (sinkholes) exists within $-2000 \mathrm{ft}$ of the site.

Unweathered Copper Ridge Dolomite along Chestnut Ridge typically consists of medium- to dark-gray, fine- to coarse-grained, medium- to thick-bedded cherty dolostone. Thickness of the Copper Ridge Dolomite ranges from 1000 to $1300 \mathrm{ft}$ near ORNL (Ketelle and Huff 1984). Strike of the unit in this area ranges from $N 45^{\circ} \mathrm{E}$ to $\mathrm{N} 70^{\circ} \mathrm{E}$, and dip averages $31^{\circ} \mathrm{SE}$. The thickness and strike of the Copper Ridge Dolomite beneath the UNC Disposal Site is unknown but is expected to be similar to that near ORNL. Measurements of apparent dip in rock cores at the UNC Disposal Site indicate a range of 10 to $50^{\circ}$ to the southeast, with an average dip of approximately $30^{\circ}$ (Geotek 198 ).

\subsubsection{Hydrogeology}

Groundwater within the Knox Group occurs in saturated residuum near the soilbedrock contact and typically within fractures and solution features in bedrock. The groundwater table occurs near the soil-bedrock interface (Geotek 1982), but the specific depth varies seasonally. Groundwater flow is influenced by the presence and orientation of fractures and solution-enlarged openings. The solutioning and enlargement of plants of weakness, such as bedding planes and fractures, are more prevalent in the upper, weathered zone of the bedrock. The number and size of the openings generally decrease with depth. 
The UNC Disposal Site is located near a groundwater divide coincident with the crest of Chestnut Ridge; hence, general groundwater flow patterns are controlled by the position of the divide relarive to the site. If the divide is positioned to the southeast of the site, groundwater flow would be toward BCV; and conversely, if the divide is to the northwest of the site, groundwater flow would be predominantly towards Bethel Valley. Haase et al. (1987) conducted a preliminary hydrogeologic assessment of the site based on five existing water table wells and concluded that, at that time, the groundwater divide was northnorthwest of the site and flow was east-northeast towards watersheds in Bethel Valley. The water table depth ranged from $-40 \mathrm{ft}$ northwest of the site to $-110 \mathrm{ft}$ northeast of the site. Vertical groundwater flow was downward.

Two additional wells (GW-339 and GW-302) were proposed by Early (1989) and were installed subsequent to the 1987 preliminary assessment (Fig. 7). These wells provided closure of the monitoring well array to the northeast of the UNC Disposal Site and additional control points for assessment of shallow groundwater flow patterns. Figure 7 is a map of the water table surface constructed from second quarter 1990 draft data. Based on these data, the groundwater divide was located west-northwest of the UNC Disposal Site, and shallow groundwater flow was east-northeast. The water table gradient across the site was $-520 \mathrm{ft} / \mathrm{mile}$.

Groundwater in the UNC Disposal Site vicinity is alkaline. Calcium and magnesium are the predominant cations, and carbonate and bicarbonate are the major anions. Groundwater from the site has a low, but consistent, silicon concentration (Haase et al. 1987). The chemical characteristics of groundwater at the UNC Disposal Site are consistent with those expected for groundwater from the siliceous dolostone comprising the Copper Ridge Dolomite underlying the site.

\subsection{Summary of Remedial Investigation}

\subsubsection{Drum and box disposal area}

The UNC Disposal Site, in general, represents a safety hazard to workers. The drums $(29,000)$ are stacked 10 high, and some have rusted and split open, thereby exposing their contents. Sharp edges created by split drums present a potential safety hazard. Many of the wooden boxes containing scrap material have broken open, and their contents have been scattered. The plastic covering the drums and boxes has deteriorated, and workers are unable to replace the plastic cover because of the instability of the drums. A high risk for industrial accidents exists at the site because of the potential of shifting and falling drums and exposed rusty, sharp metal. Therefore, in their present condition, the drums and boxes, even though nonhazardous, are more likely to adversely affect workers and the environment. In addition, the nature of material emplacement and plastic covering creates a habitat for snakes and rodents. 


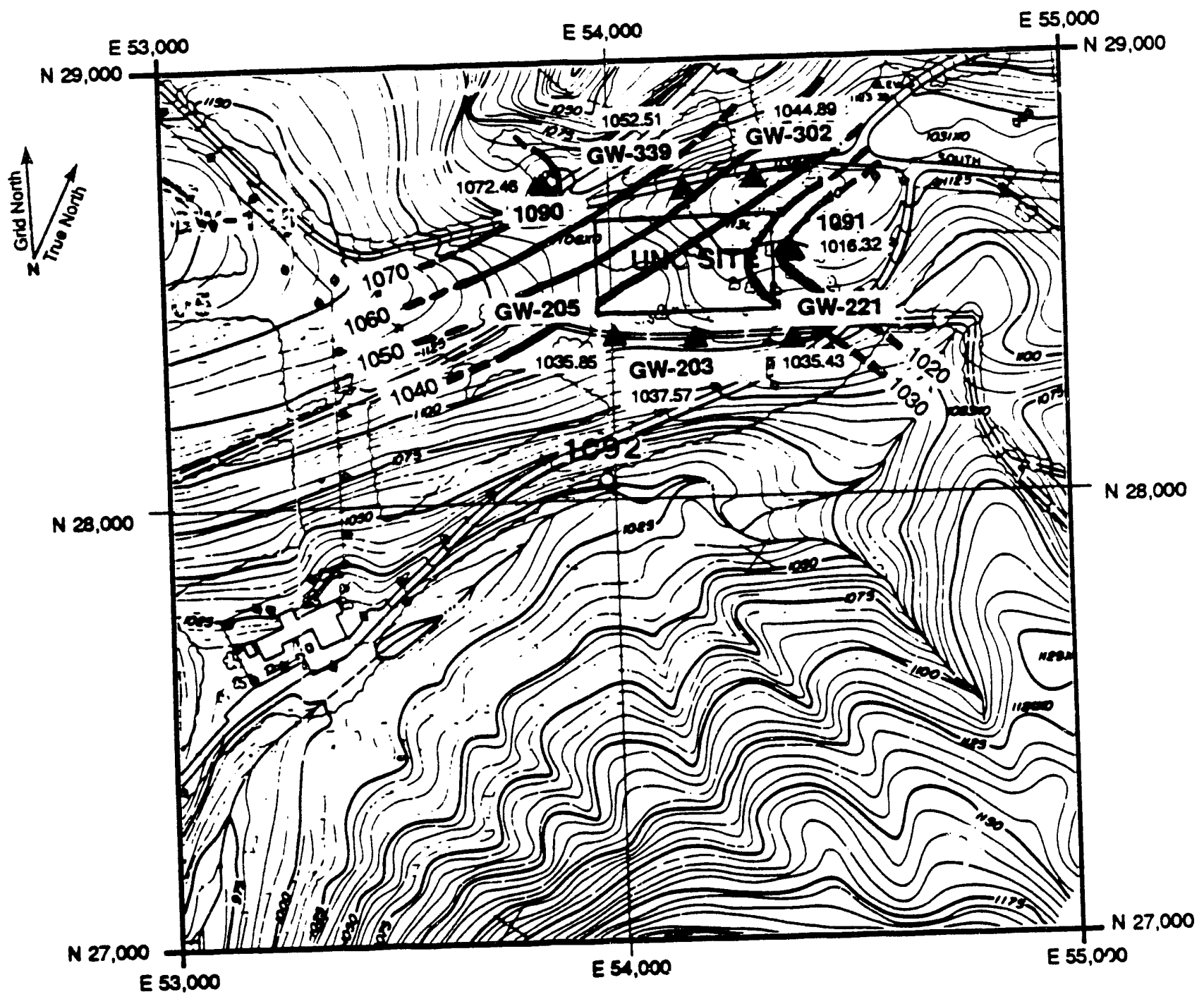

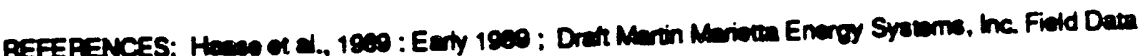

Scale: $1: 4800$

C.I. $=5$ feet

Groundunar table elovations

in toet above meen sea love

Grid Coordinates Based on Y-12

Plant Administrative Grid System

MARTIN MARIETTA ENERGY SYSTEMS, INC.

Fig. 7. Well locations and water table map for the UNC Disposal Site, second quarter, 1990 


\subsubsection{Wooden boxes}

There are 288 boxes located at the site. The boxes are approximately the size of a pallet and made of plywood held together by metal strapping. They are located in front of the stacked drums and many have split open, spilling their contents. Contents of the boxes vary from miscellaneous industrial scrap material (piping, conveyors, industrial scrap, etc.) to sand in plastic bags. A walk-over radiological survey of the drums and boxes was conducted by Y-12 Plant Health Physics in August 1990. Field screening measurements indicated elevated beta/gamma readings in several areas, mainly associated with the materials inside the wooden boxes. Two of the beta/gamma readings were greater than the Y-12 Plant beta/gamma release limit of $5000 \mathrm{dpm} / 100 \mathrm{~cm}^{2}$. All alpha readings were below the detection limit.

\subsubsection{Drummed soils/sludges}

During 1985, Martin Marietta Energy Systems, Inc. (Energy Systems) subjected 82 samples from 76 randomly selected drums at the UNC Disposal Site to the RCRA extraction procedure (EP) toxicity leach test for hazardous waste characterization. Half of the samples were from drums containing soil, and half of the samples were from drums containing sludges mixed with cement (Kirkpatrick and McCall 1986).

The EP toxicity extract was analyzed for a wide range of constituents in addition to the metals, herbicides, and pesticides typically required in accordance with RCRA. The wastes were also tested for RCRA corrosivity, hazardous waste characteristics, moisture content, and radionuclides. A summary of the results separated into RCRA and non-RCRA parameters is presented in Tables 1 and 2, respectively.

According to Kirkpatrick and McCall (1986), the soil samples obtained from the drums were noncorrosive. Several samples of sludge mixed with cement had $\mathrm{pH}$ values $>12$; however, none of the samples exceeded the regulatory limit of 12.5. Similarly, none of the extracts contained contaminant concentrations exceeding regulatory limits set forth under RCRA. Most contaminant concentrations were below the detection limits or levels measured in blanks.

With the exception of strontium-90 and nitrate, all other analytes were below the SDWA maximum contaminant level (MCL) regulatory criteria. The concentrations of nitrates in the EP toxicity leachate ranged from $<0.5 \mathrm{mg} / \mathrm{L}$ to $8880 \mathrm{mg} / \mathrm{L}$. The highest concentrations of nitrates were found in extracts obtained from the sludges that were mixed with cement. A total nitrate (as nitrogen) inventory for the site was estimated by assuming that the volume of leachate used in the EP test effectively dissolved all of the leachable nitrate in a specified mass of the sample. As presented in Table 3, a nitrate (as nitrogen) inventory of $\sim 53 \mathrm{t}$ was calculated using the availahle data and the referenced assumptions. 


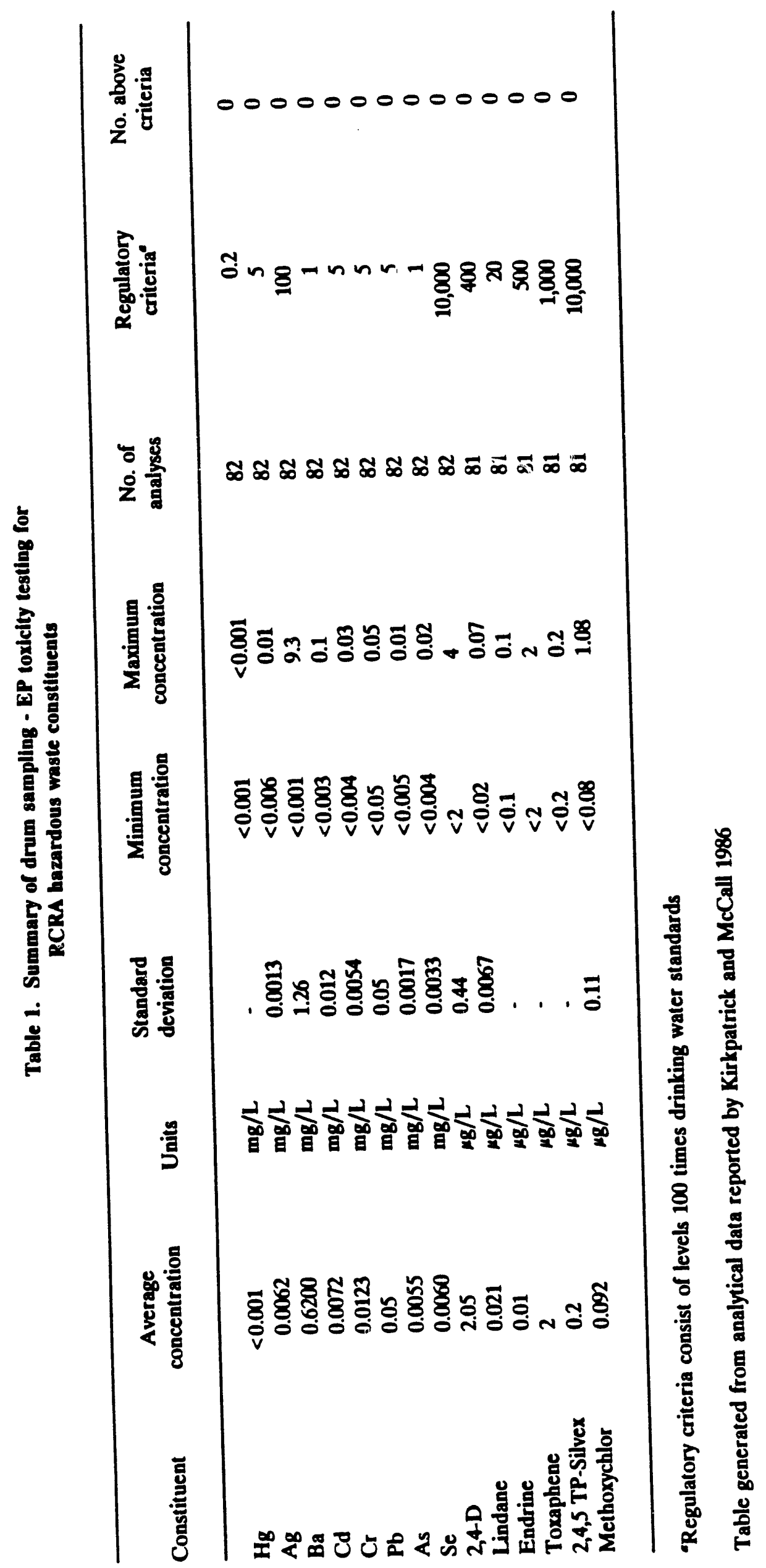




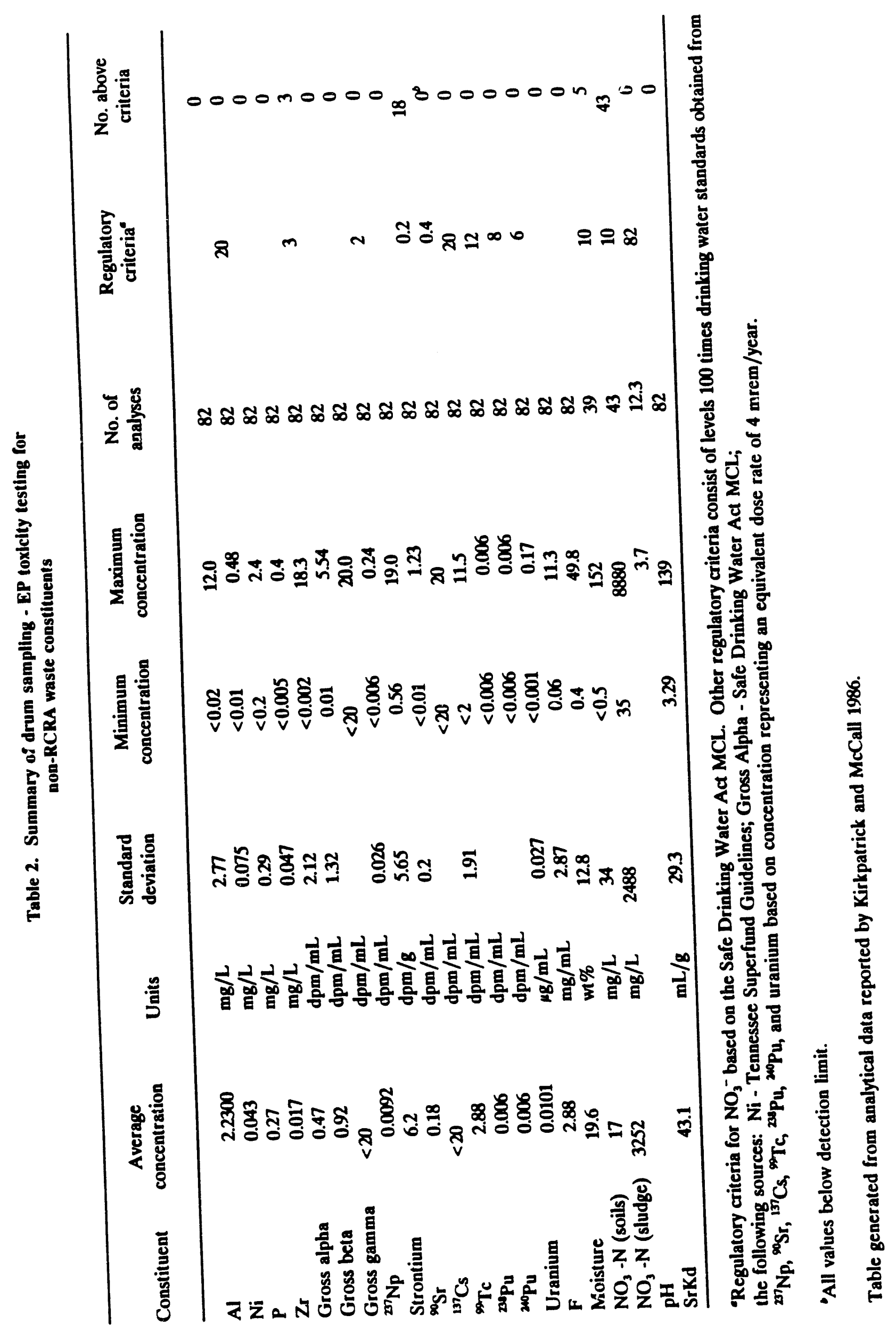


Table 3. Nitrate inventory

\begin{tabular}{lcc}
\hline \multicolumn{1}{c}{ Assumptions/data } & Sludges & Soils \\
\hline Average moisture content & $29.1 \%$ & $9.5 \%$ \\
Solution to solid ratio for EP-toxicity test & $20 \mathrm{~mL} / \mathrm{g}$ & $20 \mathrm{~mL} / \mathrm{g}$ \\
Average $\mathrm{NO}_{3}^{-}$in extract & $3252 \mathrm{mg} / \mathrm{L}$ & $17 \mathrm{mg} / \mathrm{L}$ \\
Assumed weight per drum & $320 \mathrm{~kg}$ & $320 \mathrm{~kg}$ \\
No. of drums & 11,000 & 18,000 \\
Calculated nitrate inventory & $232 \mathrm{t}$ & $2 \mathrm{t}$ \\
Calculated nitrate (as N) inventory & $52.4 \mathrm{t}$ & $0.5 \mathrm{t}$ \\
& Total $\mathrm{NO}_{3}^{-}-\mathrm{N}$ inventory $=53 \mathrm{t}$ (58 tons)
\end{tabular}

Reference: Weston 1986 
The inventory of strontium-90 was estimated by assuming the same average weight and number of drums and using the average of $6.2 \mathrm{dpm} / \mathrm{g}$ of strontium-90 in the solids. An estimated inventory of $25 \mathrm{mCi}$ of strontium-90 was calculated.

\subsubsection{Adjacent soils}

In 1986, several soil samples were obtained from the vicinity of the UNC Disposal Site and analyzed by Oak Ridge K-25 Site-Analytical Chemistry Division (ACD) for heavy metals and nitrates (Weston 1986). Two holes were augered within the excavated pit immediately downgradient of the stacked drums (exact location unknown). Shelby-tube samples were obtained from various intervals over the $20-\mathrm{ft}$ core lengths. Data for background soil concentrations were obtained from the first $3 \mathrm{ft}$ of soil at two unspecified locations east and west of the disposal site and from the archived cores taken during installation of a nearby groundwater monitoring well (GW-173, located $\sim 1$ mile east of the UNC pit on Chestnut Ridge). A summary of the results of analytical testing for these soils is presented in Table 4.

The analytical results indicated that heavy metal concentrations were higher than background levels typical of soils derived from limestones and dolomites (Freeze and Cherry 1979). However, all of the samples exhibited similar metal concentrations, and the higher concentrations were not limited to the shallow soil depths. Some of the greatest concentrations were observed in soil samples taken at a depth of $25 \mathrm{ft}$ during drilling of well GW-173. The low levels of nitrates observed in the samples appear to indicate that the wastes at the site have not leached into the vadose zone.

\subsubsection{Groundwater}

Seven groundwater monitoring wells at the UNC Disposal Site (Fig. 7) are now sampled quarterly and analyzed for metals, various radioactive species, nitrates, and other conventional water quality parameters. However, because two of these wells (GW-302 and GW-339) were installed in 1989, a comprehensive groundwater quality data base exists only for the five older wells. Before 1987, these wells were analyzed for a suite of parameters substantially more extensive than now, including volatile organics, herbicides, and pesticides, in addition to the current parameters. Wells GW-203, GW-205, and GW-221 were completed in the weathered zone above the bedrock. Wells 1090 and 1091 were completed in the top of bedrock. Construction details of these wells are summarized in Haase et al. (1987a, 1987b).

Groundwater monitoring of the UNC Disposal Site has been conducted since 1986. Several reports have evaluated the results of the monitoring data from 1986 to 1988 . Haase et al. (1987) reported the results of the groundwater chemical analyses for 1986. They concluded that there was no evidence of migration from the UNC Disposal Site. During calendar years 1987 and 1988, a more restricted suite of groundwater chemical analyses was performed with an overall goal of detecting the initiation of contaminant migration. Early 
Table 4. Representative results of area soil analyses $(\mu \mathrm{g} / \mathrm{g})$

\begin{tabular}{|c|c|c|c|c|c|c|c|}
\hline Sample No. & Interval $(\mathrm{ft})^{q}$ & $\mathrm{Cr}$ & $\mathrm{Cu}$ & $\mathrm{Ni}$ & As & $\mathrm{Pb}$ & $\mathrm{NO}_{3}$ \\
\hline$S T-1^{b}$ & $\begin{array}{c}0-1 \\
4-5.4 \\
10-10.3 \\
18-20\end{array}$ & $\begin{array}{l}77 \\
63 \\
29 \\
53\end{array}$ & $\begin{array}{l}31 \\
37 \\
28 \\
28\end{array}$ & $\begin{array}{l}48 \\
66 \\
37 \\
53\end{array}$ & $\begin{array}{l}70 \\
72 \\
44 \\
40\end{array}$ & $\begin{array}{l}67 \\
56 \\
77 \\
98\end{array}$ & $\begin{aligned} & 48 \\
< & 1.0 \\
< & 10 \\
< & 10\end{aligned}$ \\
\hline $\mathrm{ST}-2^{b}$ & $\begin{array}{c}0-0.3 \\
6.4-7 \\
10.4-11.2 \\
18-20\end{array}$ & $\begin{array}{l}25 \\
24 \\
23 \\
17\end{array}$ & $\begin{array}{l}24 \\
28 \\
32 \\
76\end{array}$ & $\begin{array}{l}26 \\
34 \\
37 \\
98\end{array}$ & $\begin{array}{l}74 \\
68 \\
72 \\
46\end{array}$ & $\begin{array}{r}74 \\
111 \\
74 \\
57\end{array}$ & $\begin{aligned} & 13.6 \\
< & 10 \\
< & 10 \\
< & 10\end{aligned}$ \\
\hline West Sample ${ }^{c}$ & $\begin{array}{l}0-2 \\
2-3\end{array}$ & $\begin{array}{l}26 \\
31\end{array}$ & $\begin{array}{l}13 \\
26\end{array}$ & $\begin{array}{l}12 \\
14\end{array}$ & $\begin{array}{l}16 \\
60\end{array}$ & $\begin{array}{l}48 \\
68\end{array}$ & $\begin{array}{l}<0.3 \\
<0.5\end{array}$ \\
\hline East Sample ${ }^{d}$ & $\begin{array}{l}0-2 \\
2-3\end{array}$ & $\begin{array}{l}24 \\
39\end{array}$ & $\begin{array}{c}9.1 \\
15\end{array}$ & $\begin{array}{l}8.0 \\
9.2\end{array}$ & $\begin{array}{l}20 \\
20\end{array}$ & $\begin{array}{l}22 \\
22\end{array}$ & $\begin{array}{l}<0.5 \\
<0.5\end{array}$ \\
\hline $\mathrm{GW}-173^{e}$ & $\begin{array}{c}5-6.5 \\
10-11.5 \\
15-16.5 \\
20-21.5 \\
25-26.5\end{array}$ & $\begin{array}{l}31 \\
15 \\
26 \\
13 \\
11\end{array}$ & $\begin{array}{r}48 \\
13 \\
60 \\
100 \\
96\end{array}$ & $\begin{array}{c}26 \\
9.5 \\
36 \\
97 \\
130\end{array}$ & $\begin{array}{l}78 \\
20 \\
70 \\
78 \\
82\end{array}$ & $\begin{array}{r}40 \\
36 \\
76 \\
128 \\
208\end{array}$ & $\begin{array}{r}<0.5 \\
25.2 \\
<0.5 \\
0.7 \\
<0.7\end{array}$ \\
\hline
\end{tabular}

${ }^{a}$ Measured from ground surface.

${ }^{b}$ ST -1 and ST-2 were obtained from the base of the excavated pit.

${ }^{c}$ West sample was obtained from an unidentified area located southwest of the UNC pit.

${ }^{d}$ East sample was obtained from an unidentified area located northeast of the UNC pit.

${ }^{e} \mathrm{GW}-173$ is located $\sim 1$ mile east of the pit on the crest of Chestnut Ridge.

Reference: Weston 1986. 
(1989) and Bailey et al. (1989) performed subsequent evaluations of these results and concluded that there was no indication of leakage from the site.

Monitoring wells GW-302 and GW-339, installed in December of 1989 to the north/nort'east of the site, were sampled in May 1990. This section evaluates the data from these two wells, as well as data collected quarterly from the five original wells in 1989 and in the first quarter of 1990.

As a screening step to determine whether migration from the site is occurring, the results of the chemical analyses are compared to water quality standards (Tables 5 through 9). Applicable water quality standards consist of primary standards established by EPA and secondary standards established by the Tennessee Department of Health and Environment (TDHE). The primary standards are maximum contaminant levels (MCLs), defined as the maximum permissible concentration of a contaminant in water measured at the free-flowing outlet of the user of a public water system. MCLs are deemed protective of public health over a lifetime ( 70 years) for a person drinking $2 \mathrm{~L}$ of water per day. The secondary water quality standards are based on aesthetic standards established by the state of Tennessee.

The overall chemical character of uncontaminated groundwater under Chestnut Ridge was determined from monitoring wells located upgradient from the waste site (Geraghty and Miller 1990). Geraghty and Miller concluded that the native groundwater under Chestnut Ridge is of the calcium-magnesium-bicarbonate type. Specific conductance ranged from 192 to $449 \mu \Omega / \mathrm{cm}$, and the $\mathrm{pH}$ ranged from 6.0 to 8.0. Dissolved concentrations of calcium and magnesium ranged from 22 to $88 \mathrm{mg} / \mathrm{L}$ and 15 to $49 \mathrm{mg} / \mathrm{L}$, respectively (Table 10). Bicarbonate concentrations (as $\mathrm{CaCO}_{3}$ ) ranged between 94 and $226 \mathrm{mg} / \mathrm{L}$. Dissolved concentrations of chloride, potassium, and sulfate were generally $<20 \mathrm{mg} / \mathrm{L}$; nitrate content was typically $<1 \mathrm{mg} / \mathrm{L}$ (Geraghty and Miller 1990). The results of gruundwater screening from the three monitoring wells located south of the UNC Disposal Site (Fig. 7) are summarized in Tables 5 through 7. Results from GW-203 indicate arsenic, iron, and manganese exceeded their respective standards in only one sample. One quarterly sample from GW-205 contained iron, manganese, and gross B activity above applicable standards. In addition, iron exceeded its standard in one other sample. Measured concentrations of arsenic, iron, and manganese are within background groundwater concentrations for Chestnut Ridge listed in Table 10. For GW-221, all chemical concentrations were below applicable standards. Although several constituents exceeded standards, the frequency of their detection and measured concentrations indicate that they are naturally occurring constituents of groundwaters of Chestnut Ridge.

Groundwater samples from well 1090 contained several constituents that exceeded standards (Table 8). Although arsenic, cadmium, chromium, iron, lead, manganese, and selenium exceeded their respective standards and background concentrations in one sample, their detection is not indicative of contamination. As previousiy suggested by Early (1989), the differences observed in well 1090 may be related to mixirg of deeper, more highly mineralized groundwaters with water of shallow origin along a rossible fracture zone. 
Table 5. Screening of groundwater samples from GW-203 to applicable standards

\begin{tabular}{|c|c|c|c|c|}
\hline Antyo & 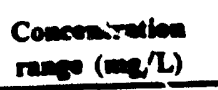 & $\begin{array}{l}\text { Sondands } \\
(\mathrm{m} / \mathrm{L} / \mathrm{L})\end{array}$ & $\begin{array}{c}\text { Frequency of } \\
\text { detection }\end{array}$ & $\begin{array}{l}\text { No of smaples grener then } \\
\text { the standand }\end{array}$ \\
\hline Aluminum & $0.022-13$ & & $5 / 5$ & \\
\hline Arsenic & 0.069 & 0.05 & $1 / 5$ & 1 \\
\hline Barium & $0.0069-0.22$ & $1.0^{\circ}$ & $5 / 5$ & 0 \\
\hline Beryllium & 0.0016 & & $1 / 5$ & \\
\hline Boron & $0.005-0.018$ & & $5 / 5$ & \\
\hline Cadmium & 0.0056 & $0.0 \mathrm{i}=$ & $1 / 5$ & 0 \\
\hline Calcium & $26-39$ & & $4 / 5$ & \\
\hline Chromium & 0.016 & 0.05 & $1 / 5$ & 0 \\
\hline Cobalt & 0.0068 & & $1 / 5$ & \\
\hline Copper & 0.026 & 1 & $1 / 5$ & 0 \\
\hline Iron & $0.017-18$ & $0.3^{\circ}$ & $5 / 5$ & 1 \\
\hline Lead & $\infty .05$ & 0.05 & $0 / 5$ & 0 \\
\hline Mngnesium & $16-25$ & & $4 / 5$ & \\
\hline Mangnnese & $0.0045-0.36$ & $0.05^{\circ}$ & $4 / 5$ & 1 \\
\hline Molybdeaum & $\infty .01$ & & $1 / 5$ & \\
\hline Nictel & $\infty .01$ & & $0 / 5$ & \\
\hline Potnatium & $0.93-4.8$ & & $4 / 5$ & \\
\hline Selenium & $\infty .05$ & $0.01^{\circ}$ & $0 / 5$ & \\
\hline Silicon & $35-46$ & & $4 / 5$ & \\
\hline Silver & $\$ 0.006$ & 0.05 & $0 / 5$ & 0 \\
\hline Sodium & $0.33-0.53$ & & $s / 5$ & \\
\hline Strontium & $0.0052-0.031$ & & $4 / 5$ & \\
\hline Thorium & $\infty .2$ & & $0 / 5$ & \\
\hline Vanedium & $\infty .005$ & & $0 / 5$ & \\
\hline Zinc & $0.012-0.14$ & $5^{6}$ & $3 / 5$ & 0 \\
\hline Groes a & $0.4-1^{0}$ & 15 & $s / 5$ & 0 \\
\hline Grose 8 & $0.9-13$ & 50 & $s / 5$ & 0 \\
\hline Chloride & 1 & $250^{\circ}$ & $s / s$ & 0 \\
\hline Nitrate & $0.69-0.9$ & $10.0^{\circ}$ & $5 / 5$ & 0 \\
\hline Sulfate & 1 & $250^{\circ}$ & $3 / 5$ & 0 \\
\hline
\end{tabular}

- Maximum contaminant levels (MCLs) established by EPA and the state.

- Aesthetic standards established by the state.

- Compound was analyzed for but not detected. The number is the attainable detection limit.

- Units for gross a and gross 8 are picocuries/liter. 
Table 6. Screening of groundwater samples from GW-205 to applicable standards

\begin{tabular}{|c|c|c|c|c|}
\hline Antyo & $\begin{array}{l}\text { Concentration } \\
\operatorname{rum}(n / L)\end{array}$ & $\begin{array}{c}\text { Standards } \\
(\text { mall }\end{array}$ & $\begin{array}{c}\text { Frequesey of } \\
\text { detection }\end{array}$ & $\begin{array}{l}\text { Na of smoles greaser } \\
\text { then the standard }\end{array}$ \\
\hline Aluminum & $0.023-3.1$ & & $4 / 5$ & \\
\hline Arcenic & $<0.0 \sigma^{\circ}$ & 0.05 & $0 / 5$ & 0 \\
\hline Barium & $0.01-0.2$ & $1.0^{\circ}$ & $5 / 5$ & 0 \\
\hline Beryllium & $<0.003$ & & $0 / 5$ & \\
\hline Boroa & 0.028 & & $1 / 5$ & \\
\hline Cadmium & 0.0034 & $0.01^{\circ}$ & $1 / 5$ & 0 \\
\hline Calcium & $29-48$ & & $4 / 5$ & \\
\hline Chromium & 0.011 & 0.05 & $1 / 5$ & 0 \\
\hline Cobalt & 0.0083 & & $1 / 5$ & \\
\hline Copper & 0.016 & $1^{\circ}$ & $1 / 5$ & 0 \\
\hline Iroa & $0.022-6.1$ & $0.3^{\circ}$ & $4 / 5$ & 2 \\
\hline Lead & $<0.05$ & $0.05^{6}$ & $0 / 5$ & 0 \\
\hline Magnesium & $17-26$ & & $4 / 5$ & \\
\hline Mangunese & $0.0003-0.24$ & $0.05^{\circ}$ & $4 / 5$ & 1 \\
\hline Molybdenum & $<0.01$ & & $0 / 5$ & \\
\hline Nictrel & $<0.01$ & & $0 / 5$ & \\
\hline Pocnasium & $0.94-4.6$ & & $4 / 5$ & \\
\hline Selknium & $<0.05$ & $0.01^{\circ}$ & $0 / 5$ & \\
\hline Silicon & $3.7-8.4$ & & $4 / 5$ & \\
\hline Silver & $<0.006$ & 0.00 & $0 / 5$ & 0 \\
\hline Sodium & $0.39-2.0$ & & $s / s$ & \\
\hline Stroatium & $0.0058-0.013$ & & $3 / 5$ & \\
\hline Thorium & $<0.2$ & & $0 / 5$ & \\
\hline Vanedium & 0.01 & & $1 / 5$ & \\
\hline Zinc & $0.006-0.041$ & $5^{\circ}$ & $2 / 5$ & 0 \\
\hline Groes a & $1-9.6$ & 15 & $s / 5$ & 0 \\
\hline Grow 8 & $5-1826$ & so & $s / 5$ & 1 \\
\hline Chloride & 1 & $250^{\circ}$ & $5 / 5$ & 0 \\
\hline Nitrate & $0.19-0.2$ & $10.0^{\circ}$ & $s / 5$ & 0 \\
\hline Sulfate & $3-4$ & $250^{\circ}$ & $5 / 5$ & 0 \\
\hline
\end{tabular}

- Maximum contaminant levels (MCLs) established by EPA and the state.

- Aesthetic standards established by the state.

- Compound was analyzed for but not detected. The number is the attainable detection limit.

- Units for gross and gross $\mathrm{B}$ are $\mathrm{pCi} / \mathrm{L}$. 
Table 7. Screening of groundwater samples from GW-221 to applicable standards

\begin{tabular}{|c|c|c|c|c|}
\hline Antyo & $\begin{array}{l}\text { Concentrotion } \\
\operatorname{ring}(m / L)\end{array}$ & $\begin{array}{l}\text { Senndards } \\
(m / L)\end{array}$ & $\begin{array}{c}\text { Frequency of } \\
\text { detection }\end{array}$ & $\begin{array}{l}\text { No. of snoples preater } \\
\text { then the stendard }\end{array}$ \\
\hline Aluminum & $0.027-0.13$ & & $s / 5$ & \\
\hline Arenic & $<0.05^{\circ}$ & 0.05 & $0 / 5$ & 0 \\
\hline Barium & $0.0031-0.13$ & $1.0^{\circ}$ & $s / 5$ & 0 \\
\hline Beryllium & $<0.0003$ & & $0 / 5$ & \\
\hline Boron & $0.015-0.017$ & & $2 / 5$ & \\
\hline Cadmium & $<0.000$ & $0.01^{\circ}$ & $0 / 5$ & 0 \\
\hline Calcium & $27-30$ & & $5 / 5$ & \\
\hline Chromium & $<0.01$ & $0.05^{6}$ & $0 / 5$ & 0 \\
\hline Cobalt & $<0.005$ & & $0 / 5$ & \\
\hline Copper & 0.0043 & 10 & $1 / 5$ & 0 \\
\hline Iroa & $0.011-0.19$ & $0.3^{\circ}$ & $5 / 5$ & 0 \\
\hline Lead & $<0.05$ & 0.05 & $0 / 5$ & 0 \\
\hline Mngnesium & 18 & & $1 / 5$ & . \\
\hline Mnggnese & $0.002-0.008$ & $0.05^{\circ}$ & $3 / 5$ & 0 \\
\hline Mohybdenum & 0.018 & & $1 / 5$ & \\
\hline Nictel & $<0.01$ & & $0 / 5$ & \\
\hline Potancium & $0.81-3.5$ & & $3 / 5$ & \\
\hline Selenium & $<0.05$ & $0.01^{\circ}$ & $0 / 5$ & \\
\hline Silicon & $3.9-4.2$ & & $3 / 5$ & \\
\hline Sitver & $<0.006$ & $0.05^{\circ}$ & $0 / 5$ & 0 \\
\hline Sodium & $0.38-0.68$ & & $4 / 5$ & \\
\hline Stroatium & 0.01 & & $1 / 5$ & \\
\hline Thorium & $<0.2$ & & $0 / 5$ & \\
\hline Vansdium & $<0.005$ & & $0 / 5$ & \\
\hline Zinc & $0.002-0.013$ & 5 & $3 / 5$ & 0 \\
\hline Groes a & $0.3-0.81^{c}$ & 15 & $5 / 5$ & 0 \\
\hline Groes 8 & $02-28$ & so & $5 / 5$ & 0 \\
\hline Chloride & 1 & $250^{\circ}$ & $5 / 5$ & 0 \\
\hline Nitrate & $0.57-1$ & $10.0^{\circ}$ & $5 / 5$ & 0 \\
\hline Sulfate & 1 & $250^{\circ}$ & $5 / 5$ & 0 \\
\hline
\end{tabular}

- Maximum contaminant levels (MCLs) established by EPA and the state.

- Aesthetic standards established by the state.

- Compound was analyzed for but not detected. The number is the attainable detection limit.

- Units for gross a and gross 8 are $\mathrm{pCi} / \mathrm{L}$.

90-008P/0191 
Table 8. Screening of groundwater samples from Well 1090 to applicable standards

\begin{tabular}{|c|c|c|c|c|}
\hline Antyos & 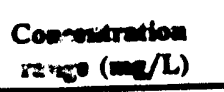 & $\begin{array}{l}\text { Standards } \\
\text { (n/L) }\end{array}$ & $\begin{array}{c}\text { Proquency of } \\
\text { detection }\end{array}$ & $\begin{array}{l}\text { No of smaples ereater } \\
\text { then the stendard }\end{array}$ \\
\hline Aluminum & $0.032-140$ & & $4 / 5$ & \\
\hline Arenic & $0.12-0.2$ & 0.05 & $2 / 5$ & 2 \\
\hline Barium & $0.020-0.9$ & 1.0 & $5 / 5$ & 0 \\
\hline Beryllium & 0.049 & & $1 / 5$ & \\
\hline Boron & $0.015-0.16$ & & $5 / 5$ & \\
\hline Cadmium & 0.02 & $0.01^{\star}$ & $1 / 3$ & 1 \\
\hline Calcium & $50-80$ & & $s / 5$ & \\
\hline Chromium & 0.20 & 0.05 & $1 / 5$ & 1 \\
\hline Cobalt & 0.24 & & $1 / 5$ & \\
\hline Copper & 0.61 & $1 *$ & $1 / 5$ & 0 \\
\hline Iron & $0.012-370$ & $0.3^{\circ}$ & $4 / 5$ & 1 \\
\hline Lend & $0.076-0.99$ & 0.05 & $2 / 5$ & 2 \\
\hline Mngenesium & $30-55$ & & $5 / 5$ & \\
\hline Manganese & $0.0019-14$ & $0.05^{\circ}$ & $3 / 5$ & 1 \\
\hline Mohybdenum & 0.013 & & $1 / 5$ & \\
\hline Nictel & $0.013-0.45$ & & $2 / 5$ & \\
\hline Pocentium & $0.9-16$ & & $5 / 5$ & \\
\hline Selenium & 0.2 & $0.01^{\circ}$ & $1 / 5$ & 1 \\
\hline Silicon & $4.1-73$ & & $5 / 5$ & \\
\hline Silver & $<0.000^{\circ}$ & 0.05 & $0 / 5$ & 0 \\
\hline Sodium & $12-14$ & & $5 / 5$ & \\
\hline Strontium & $0.022-0.026$ & & $4 / 5$ & \\
\hline Thorium & $<02$ & & $0 / 5$ & \\
\hline Vandium & $<0.005$ & & $0 / 5$ & \\
\hline Zinc & $0.0048-32$ & $5^{\circ}$ & $4 / 5$ & 0 \\
\hline Groes a & $0.59-12$ & 15 & $5 / 5$ & 0 \\
\hline Groes : & $1.6-329$ & 50 & $5 / 5$ & 0 \\
\hline Crloride & $22-35$ & $250^{\circ}$ & $5 / 5$ & 0 \\
\hline Nitunte & $0.84-1$ & $10.0^{\circ}$ & $5 / 5$ & 0 \\
\hline Sulface & 3 & $250^{\circ}$ & $5 / 5$ & 0 \\
\hline
\end{tabular}

- Maximum contaminant levels (MCLs) established by EPA and the state.

- Aesthetic standards established by the state.

- Compound was analyzed for but not detected. The number is the attainable detection limit.

- Units for gross a and gross 8 are $\mathrm{pCi} / \mathrm{L}$. 
Table 9. Screening of groundwater samples from Well 1091 to applicable standards

\begin{tabular}{|c|c|c|c|c|}
\hline Andyo & rencention & $\begin{array}{c}\text { sendards } \\
(n, / L)\end{array}$ & $\begin{array}{c}\text { Frnquency of } \\
\text { detection }\end{array}$ & $\begin{array}{l}\text { No of smaples arenter } \\
\text { then the standard }\end{array}$ \\
\hline Aluminum & $0.022-0.073$ & & $5 / 5$ & \\
\hline Arcenic & $0.07-0.12$ & 0.05 & $2 / 5$ & 2 \\
\hline Barium & $0.007-0.063$ & $1.0^{\circ}$ & $5 / 5$ & 0 \\
\hline Beryllium & $<0.0000$ & & $0 / 5$ & \\
\hline Boroa & $0.009-0.002$ & & $3 / 5$ & \\
\hline Codminem & 0.006 & $0.01^{\circ}$ & $1 / 5$ & 0 \\
\hline Calcium & $21-23$ & & $5 / 5$ & \\
\hline Chromiuns & $<0.01$ & 0.00 & $0 / 5$ & 0 \\
\hline Cobalt & $<0.005$ & & $0 / 5$ & \\
\hline Copper & 0.0048 & $1^{\circ}$ & $1 / 5$ & 0 \\
\hline Iron & $0.007-0.0033$ & 0.3 & $s / 5$ & 0 \\
\hline Lend & $<0.05$ & 0.05 & $0 / 5$ & 0 \\
\hline Magecsiun & $10-16$ & & $5 / 5$ & \\
\hline Nongenese & $0.002-0.004$ & $0.00^{\circ}$ & $4 / 5$ & 0 \\
\hline Mohydenum & $<0.01$ & & $0 / 5$ & \\
\hline Nicted & 0.014 & & $1 / 5$ & \\
\hline Poterium & $33-55$ & & $5 / 5$ & \\
\hline Selenivan & $<0,05$ & $0.01^{\circ}$ & $0 / 5$ & \\
\hline Silicon & $38-42$ & & $5 / 5$ & \\
\hline Siver & $<0.006$ & 0.05 & $0 / 5$ & 0 \\
\hline Sodium & $15-1.9$ & & $5 / 5$ & \\
\hline Strontium & $0.011-0.04$ & & $4 / 5$ & \\
\hline Thorium & $<0.002$ & & $0 / 5$ & \\
\hline Vansdium & $<0.005$ & & $0 / 5$ & \\
\hline Zinc & $0.015-0.019$ & 5 & $2 / 5$ & 0 \\
\hline Groes 9 & $0.41-1.9$ & 15 & $5 / 5$ & 0 \\
\hline Gros 8 & $1.45-675$ & so & $5 / 5$ & 1 \\
\hline Chloride & $2-6$ & $250^{\circ}$ & $s / 5$ & 0 \\
\hline Niturese & $0.6-1$ & $10.0^{\circ}$ & $5 / 5$ & 0 \\
\hline Sulfate & 1 & $250^{\circ}$ & $s / 5$ & 0 \\
\hline
\end{tabular}

- Maximum contaminant levels (MCLs) established by EPA and the state.

- Acethetic standards established by the state.

- Compound was analyzed for but not detected. The number is the antainable detection imit.

- Units for gross a and gross s are $\mathrm{pCi} / \mathrm{L}$. 
Table 10. Background groundwater metal concentrations for Chestnut Ridge ${ }^{a}$

\begin{tabular}{ll}
\hline Metal & Concentration $(\mathrm{mg} / \mathrm{L})$ \\
\hline Aluminum & $36-<0.02$ \\
Arsenic & $0.03-<0.005$ \\
Barium & $0.43-0.0075$ \\
Beryllium & $0.0091-<0.0003$ \\
Boron & $0.59-<0.004$ \\
Cadmium & $<0.002$ \\
Calcium & $88-22$ \\
Chromium & $0.016-<0.01$ \\
Cobalt & $0.012-<0.005$ \\
Copper & $0.064-<0.004$ \\
Iron & $60-0.021$ \\
Lead & $0.079-<0.004$ \\
Magnesium & $49-15$ \\
Manganese & $0.79-0.0043$ \\
Mercury & $0.00023-<0.0002$ \\
Molybdenum & $0.017-<0.01$ \\
Nickel & $0.43-<0.10$ \\
Potassium & $11-<0.6$ \\
Selenium & $<0.05$ \\
Silicon & $31-2.1$ \\
Silver & $<0.006$ \\
Sodium & $6.6-4.3$ \\
Thorium & $<0.2$ \\
Uranium & $0.018-<0.001$ \\
Vanadium & $0.14-<0.005$ \\
Zinc & $0.84-<0.001$ \\
& \\
&
\end{tabular}

a Source: Geraghty \& Miller, Inc. (1990) 
Furthermore, the concentrations of these metals can be expected in the calcium-magnesiumbicarbonate groundwaters under Chestnut Ridge. Arsenic exceeded its MCL in the other 4 samples, and lead was detected above its MCL in one other sample. Their concentrations, however, were within background levels listed in Table 10.

The results of the groundwater chemical analyses screening from well 1091 indicate two samples contained arsenic above the MCL, and in one sample gross B activity was above the standard (Table 9). All other analytes in groundwater from well 1091 were below the standards.

Because wells GW-302 and GW-339 were recently installed, only one groundwater sample has been collected from each well. For these two wells, concentrations of metals, other inorganic constituents, and radionuclides did not exceed applicable standards. The concentrations of constituents without standards were below detection limits or were low and considered to be common constituents of the groundwaters under Chestnut Ridge.

The water quality analyses of samples collected from the seven UNC Disposal Site assessment wells during 1989 and the first quarter of 1990 show no indication of leakage from the site. Detectable concentrations of metals during 1989 and 1990 were commonly below applicable federal drinking water MCLs or within ranges observed in background wells located on Chestnut Ridge. In a few instances, as previously described, metal concentrations did exceed standards. However, these occurrences were isolated and no trends were observed. The detected metal concentrations are supported by historical groundwater data at the site and are representative of the groundwater chemistry of Chestnut Ridge.

\subsubsection{Potential pathways to the environment}

The results of sampling and analysis programs conducted on the UNC wastes indicated nitrate and strontium-90 to be the only contaminants of concern. Migration pathways considered to have potential impact and requiring evaluation are surface water and groundwater routes.

Migration of nitrates from the UNC Disposal Site via surface water and groundwater pathways was evaluated using a water balance computation and a two-dimensional groundwater contaminant transport simulation. The water balance was estimated using EPA's Hydrologic Evaluation of Landfill Performance, or HELP model (Weston 1986). The results of the HELP simulations were manipulated to support the data input requirements of the WMPLUME model (Beljin 1985) used to simulate contaminant transport through groundwater. The simulations, performed in 1985, were based on the existing conditions at the site, which represented an "uncapped, exposed" excavation. 
Required input variables included waste characteristics and soil, geological, and climatological data. In the absence of specific data, conservative assumptions were made based on characteristics of the site and boundary conditions of the model (Weston 1986, 1990).

Based on the waste analysis, available site-specific data, and relevant assumptions, the simulations predicted the following:

1. Nitrate-contaminated and strontium-90 leachate would reach the groundwater table in $\sim 10$ years.

2. Approximately 3 years beyond the time at which leachate reaches the groundwater system, the plume of contamination would have reached steadystate conditions. A maximum concentration of $\sim 193 \mathrm{mg} / \mathrm{L}$ (as nitrogen) for nitrate (Weston 1986) and $50 \mathrm{pCi} / \mathrm{L}$ for strontium-90 (Weston 1990) was found.

3. The average contribution of nitrate (as nitrogen) to the nearest surface water tributary would range from -10 to $30 \mathrm{mg} / \mathrm{L}$, depending on the extent of groundwater discharge to the stream (baseflow).

These estimates are conservative because the simulations assumed leach rates based on the EP toxicity tests in which the waste is in constant contact with the solvent. Accordingly, potential contaminant concentrations in groundwater at the site may be lower. However, if groundwater flow near the site is governed by fractures and subsurface conduits, concentrations may be higher due to decreased aquifer or vadose zone residence time, both of which lessen biological uptake.

\subsection{RISK ASSESSMENT}

The following baseline risk assessment and associated sections throughout this report were performed by the Office of Risk Analysis, Health and Safety Research Division, ORNL.

This baseline human health risk assessment is an analysis of the potential adverse health effects (current and future) caused by the waste materials stored at the UNC Disposal Site. The baseline risk assessment contributes to the site characterization and subsequent development, evaluation, and selection of appropriate response alternatives. The results of the baseline risk assessment will be used to

1. document the magnitude of risk at the site and the primary cause(s) of that risk,

2. help determine whether additional response action is necessary at the site, and

3. help support selection of an appropriate remedial alternative. 
The amount of detail and the extent to which qualitative and quantitative analyses are used in future risk assessments are dependent on the complexities of this site and the availability of advisories, guidance, and other criteria.

\subsubsection{Selection of Contaminants of Concern}

The initial step in the preparation of a future risk assessment is to examine the validity and appropriateness of the sampling data and to select the contaminants that may pose a current or future risk to human health. The environmental characteristics of the UNC Disposal Site were discussed in detail in Sect. 1.2.4; however, the specific conclusions used in the risk assessment are summarized here. Environmental media exhibit no evidence of past releases; however, a further evaluation of nitrate and strontium-90 is warranted for several reasons. Although the groundwater monitoring data indicate that migration of contaminants from the site has not occurred, results of the EP toxicity test indicate that both nitrate and strontium -90 possess the greatest potential to migrate from the drums. Also, these constituents were estimated to be present in the drums at high concentrations. Based on their source inventory concentration and upon their toxicological, physical, chemical, and environmental fate characteristics, these constituents were deemed most likely to contribute to potential human risk. A detailed evaluation of the health risks associated with nitrate and strontium-90 is provided in the following sections. Additionally, the health risks are discussed in the context of each treatment alternative proposed for the site.

\subsubsection{Exposure Assessment}

The exposure assessment integrates information on the environmental setting of the site and contaminant concentration data, provided in previous sections of this report, with exposure characteristics determined by the risk assessor. This integration occurs in three steps:

1. characterization of exposure setting,

2. identification of exposure pathways, and

3. quantification of exposure.

\subsubsection{Characterizing the exposure setting}

Characterizing the exposure setting involves identifying the general physical characteristics of the site and the characteristics of the populations on and near the site. This procedure ensures that all potential contaminant migration pathways and potential receptors are evaluated in the risk assessment.

The physical and environmental characteristics of the UNC Disposal Site have been discussed in Sect. 1.2.3. Demographic information such as land use, population density, and 
receptor locations are discussed in Sect. 1.2.4. Based on this information, evaluation of risk will be limited to individuals who may be exposed at the UNC Disposal Site. These individuals include waste management personnel and maintenance workers.

\subsubsection{Identifying exposure pathways}

The identification of exposure pathways is determined by evaluating all components (source, transport medium, potential receptors, and routes of exposure) necessary to complete the potential exposure pathway. For an exposure pathway to be considered valid, each component must be identified and linked to each other.

The potential transport media evaluated were air, soil, surface water, and groundwater. Releases of contaminants to the atmosphere are not likely because potential contaminants are nonvolatile and contained within drums or boxes. As described earlier, results of the soil sampling (Weston 1986) indicate that soils within the pit area were not contaminated at that time. Results of the chemical analyses of groundwater monitored at the UNC Disposal Site indicate that the drum contents have not leached to the water table. No media now exhibit evidence of past releases from the UNC Disposal Site.

Direct access by the general public is unlikely now, or any time within the foreseeable future, due to the location of the site on ORR. Employees of the DOE facilities are the most likely exposed population, and only a small percentage of these employees are expected to enter the UNC Disposal Site. Because the site is outside the main plant area, most plant employees do not come into contact with the site. The only potential receptors are the maintenance workers who monitor the site.

To properly evaluate potential exposure pathways at the site, consideration must be given to present and future activities. The only ongoing activity that involves the potential for exposure is the periodic monitoring of the drums and boxes at the site by maintenance workers. Therefore, the maintenance worker scenario is the only one considered for present activities at the site.

\subsubsection{Quantification of exposure}

Exposure in the context of human health risk is defined as the direct contact of a person with a chemical or physical agent. To quantify exposure, exposure concentrations must be determined and chemical intakes calculated for the various pathways identified at the site. No complete exposure pathways are now associated with air, soil, surface water, or groundwater. The only ongoing activity at the UNC Disposal Site where potential contact with wastes could arise is the routine monitoring of the drums and boxes. This routine monitoring consists of visual observation of the drums and boxes or a walk-over survey of the area. Direct contact with the drums or boxes does not occur. Because the wastes are contained within the drums or boxes and workers do not come into direct contact with the wastes, the only potential exposure is from ionizing radiation (Sect. 1.2.5.2). 
In summary, quantification of exposure is not required for air, soil, surface water, or groundwater because these media are associated with incomplete exposure pathways. A qualitative evaluation of exposure to ionizing radiation is limited to field screening measurements. These measurements indicate elevated beta/gamma readings that exceed limits for the Y-12 Plant.

\subsubsection{Toxicity Assessment}

The purpose of the toxicity assessment is to evaluate the potential for site contaminants to cause adverse health effects in exposed individuals. The tc xicity assessment generally involves two steps. The first step involves determining whether exposure to an agent can cause an increase in the incidence of a particular health effect and whether that health effect will occur in humans. The second step involves characterizing the relationship between the dose of the contaminant that is received and the incidence of adverse health effects in exposed populations.

A major distinction in the classification of toxic effects is between carcinogenic and noncarcinogenic effects. Noncarcinogenic responses are believed to be associated with a finite threshold dose, below which adverse responses are not elicited. A single compound might elicit several adverse effects depending on the (1) dose and (2) duration and route of exposure. Toxicity criteria, or standards for a compound, are based on the lowest dose that elicits an adverse response in the most sensitive test organism. The dose is called the reference dose (RfD). Thus, in assessing risks, it is the most sensitive response that is the determinant of whether exposure is acceptable or not.

Carcinogenic effects are considered to be the end result of a multistage process in which a large number of biological and environmental factors interact, simultaneously or in sequence, to disrupt normal cell growth and division. Because the effects of cancer are believed to occur at the molecular level, current regulatory policy is based on the concept that there is no finite dose or threshold below which carcinogens will exert an effect. For carcinogenic effects, EPA uses a two-part evaluation in which the substance is first assigned a weight-of-evidence classification and is then assigned a slope factor. The weight-ofevidence classification determines the likelihood of a substance being a human carcinogen. The slope factor quantitacively defines the relationship between dose and response and is used in risk assessments to estimate an upper-bound lifetime probability of an individual developing cancer as a result of exposure to a particular level of a potential carcinogen.

The following contaminant-specific information provides a discussion on health effects relating to nitrate and strontium-90 for the UNC Disposal Site. Both carcinogenic and noncarcinogenic health effects are considered. Toxicity values associated with strontium-90 and nitrate are summarized in Tables 11 and 12, respectively. Data from human and laboratory research along with data from occupational studies are used to characterize potential health effects resulting from exposure to these constituents. 


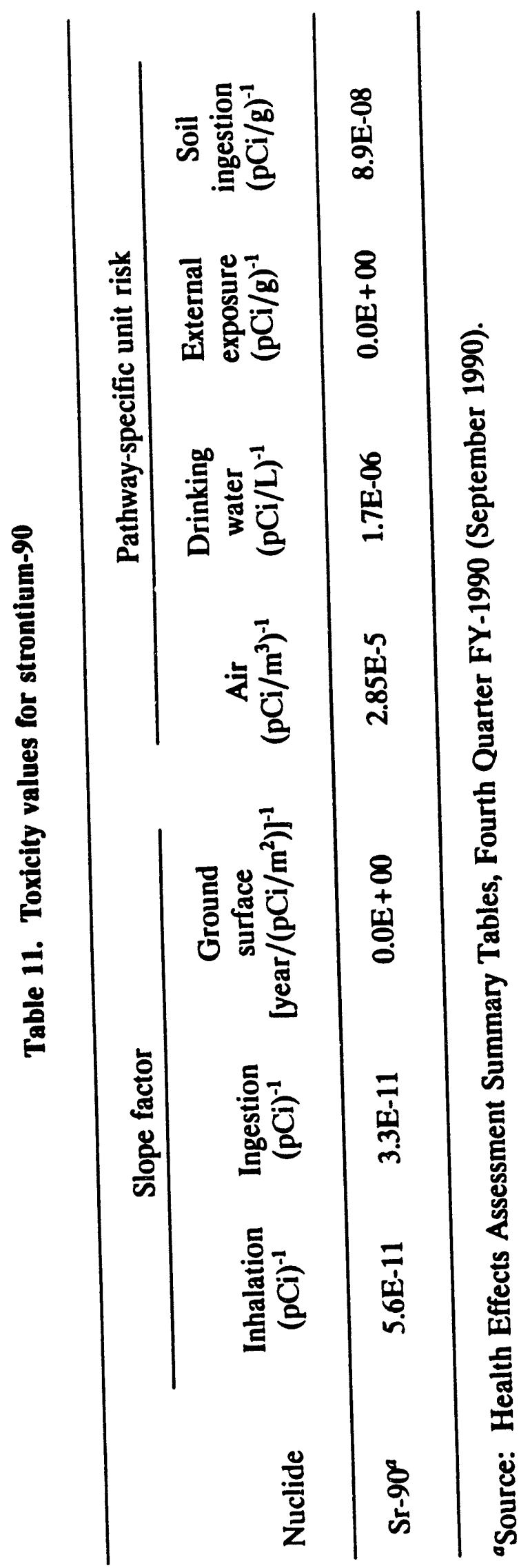


Table 12. Toxicity information for nitrate

\begin{tabular}{lcccccc}
\hline & $\begin{array}{c}\text { RfD } \\
(\mathrm{mg} / \mathrm{kg}-\mathrm{d})\end{array}$ & $\begin{array}{c}\text { Confidence } \\
\text { level }\end{array}$ & $\begin{array}{c}\text { Critical } \\
\text { effect }\end{array}$ & $\begin{array}{c}\text { RfD basis } \\
\text { (vehicle) }\end{array}$ & $\begin{array}{c}\text { RfD } \\
\text { uncertainty } \\
\text { adjustment }\end{array}$ & $\begin{array}{c}\text { Modifying } \\
\text { factor }\end{array}$ \\
\hline Nitrate $^{a}$ & 1.6 & Medium & Methemoglobemia & Water & 100 & 1 \\
\hline
\end{tabular}

'Source: EPA's RfD Work Group Meeting Notes (August 22, 1990). 


\subsubsection{Nitrate}

Nitrate is not listed as a hazardous constituent by EPA. However, the federal drinking water standard is $10 \mathrm{mg} / \mathrm{L}$ of nitrate (as nitrogen). Acute nitrate poisoning is very rare because a one-time ingestion of $0.5 \mathrm{gm}$ is required. However, chronic exposure to nitrates results in methemoglobemia in infants $<3$ or 4 months old due to conversion of nitrates to nitrites in the gastrointestinal tract. Nitrate has a Group D cancer classification, meaning there are insufficient data from which to determine evidence of carcinogenicity in humans or animals. There has been no evidence of mutagenicity related to nitrate exposures.

\subsubsection{Strontium-90}

The principal adverse biological effects associated with ionizing radiation from radioactive substances in the environment are carcinogenicity, mutagenicity, and teratogenicity. Carcinogenicity is the ability to produce cancer. Mutagenicity is the ability to induce genetic mutations in the nuclei of either body cells or reproductive cells. Teratogenicity is the ability to induce or increase the incidence of congenital malformations, which are permanent structural or functional deviations produced during growth and development of the fetus.

EPA classifies strontium-90 as a Group A carcinogen because ionizing radiation is known to be carcinogenic in humans and animals. Strontium is acquired by humans primarily through ingesting strontium-90 contaminated food. It is retained by the body largely in bone and may inhibit bone calcification. Absorption of strontium-90 by the body is relatively high, and it has a long biological retention time. Effects of acute strontium toxicity include excessive salivation, vomiting, colic, and diarrhea. Animal studier have also shown acute effects to strontium exposure and include respiratory failure in rats.

\subsubsection{Risk Characterization}

For the assessment of human health risks, two approaches are used, depending on whether the toxic endpoint has a threshold (noncarcinogenic) or no threshold (carcinogenic) effect. Noncarcinogenic hazards are quantified as the ratio of the exposure dose to a verified $\mathrm{RfD}$. This ratio is termed a hazard quotient (HQ), and an $\mathrm{HQ}<1.0$ is an indication that exposure levels are below those that have been associated with any adverse effects. Thus, an HQ $<1.0$ is generally used as the basis for designating an acceptable level of exposure to noncarcinogens.

Cancer risks are based on extrapolated hypothetical lifetime excess cancer incidences. Risks are estimated as the incremental probability of an individual developing cancer over a lifetime as a result of exposure to the carcinogen (i.e., incremental or excess individual lifetime cancer risk). The carcinogenic risk estimate represents an upper-bound estimate because slope factors are in the upper $95 \%$ confidence limit on the probability of a 
carcinogenic response. Thus, there is only a $5 \%$ probability that the actual risk is higher than the estimate presented and may very likely be less than the estimate. The cancer risk is the product of the exposure dose multiplied by the cancer slope factor. Cancer risk levels within the range of $1 \times 10^{-4}$ to $1 \times 10^{-6}$ are within the range of concern (EPA 1989). Cancer risk levels $<1 \times 10^{-6}$ are considered acceptable. Cancer risk levels $>1 \times 10^{-4}$ are an indication that exposure levels are probably unacceptable.

The purpose of this risk characterization for the UNC Disposal Site is to integrate and summarize the information presented in the toxicity and exposure assessments. Characterization of current risks consists of a qualitative evaluation of the walk-over radiological survey. Results of the survey indicated that elevated beta/gamma readings were associated with several of the boxes (Sect. 1.2.5.2). When radiation contamination release limits are exceeded, Y-12 Plant Health Physics is notified, and a course of action is determined to ensure worker protection. Further risk characterization is not warranted because no media exhibit evidence of past releases as previously described (Sect. 1.2.5.2). Hazard quotients and cancer risks are not calculated because exposure pathways are incomplete.

To provide perspective on the potential for nitrate and strontium-90 to affect human health adversely, hazard quotients and cancer risks are determined for each alternative. The derivation of these values is explained in the detailed analysis sections for each alternative. The evaluation of human health risks associated with each treatment alternative is used in the selection process for choosing the most appropriate alternative. 


\section{IDENTIFICATION OF RESPONSE ACTIONS AND TECHNOLOGIES}

\subsection{OVERVIEW}

This chapter presents the process for identifying remedial action objectives, cleanup criteria and guidelines, and assembling potential responses for the UNC Disposal Site.

Remedial action objectives for the UNC Disposal Site have been developed by assessing the potential for exposure to contaminants and associated risks to human health and the environment. The remedial action objectives are based on information and data developed and presented in the documents representing the surrogate RI (Sects. 1.2 and 1.3). The objectives address the following items:

1. contaminant of concern,

2. extent of contamination,

3. site characteristics that effect the transport of contaminants,

4. pathways of exposure for human and ecological receptors, and

5. human health and environmental risk.

According to the NCP statutes, the primary objectives of an appropriate response should be "consistent with a permanent remedy to prevent or minimize the release of hazardous substances or pollutants or contaminants so that they do not migrate to cause substantial danger to present or future public health or welfare of the environment" (U.S. EPA 1985). Preference must be given to responses that imply treatment as a permanent remedy. Responses developed for this portion of the FS, in line with NCP guidelines, include only source control actions that prevent or minimize migration of constituents from the source material (drummed soil/sludge and scrap material). Only source control actions are necessary because no contamination of groundwater, surface water, and soil was identified by the remedial investigations; however, modeling indicated potential impact to groundwater and surface water if the site remained as is.

\subsection{IDENTIFICATION OF MEDIA}

Results of studies representing the surrogate RI show that the contents of the drums and boxes stored at the UNC Disposal Site are contaminated. However, contamination of environmental media in the area has not been identified (Sect. 1.2.5). Surface water would be affected by the site only through groundwater pathways or direct runoff across the site. The quantities and characteristics of scrap and drummed material at the site are described in Sects. 1.2.5.2 and 1.2.5.3, respectively. 


\subsection{APPLICABLE OR RELEVANT AND APPROPRIATE REQUIREMENTS}

The UNC Disposal Site was placed on NPL in 1989. Subsequently, EPA required the investigation for closure and required that the selection of a remedial action for the site follow CERCLA guidelines (Sect. 1.2.2).

Section 121(d) of CERCLA, as amended by SARA, requires that remedial actions at CERCLA sites comply with requirements or standards under federal and state environmental laws that are "applicable" or "relevant and appropriate" to the hazardous substances, pollutants, or contaminants at a site or to the circumstances of the release. These requirements, known as "ARARs," may be waived only under certain circumstances specified in Sect. 121(d)(4) of CERCLA.

ARARs are derived from both federal and state laws. Under Section 121(d)(2), the federal ARARs for a site could include requirements under any of the federal environmental laws (e.g., the Clean Air Act, the Clean Water Act, and the Safe Drinking Water Act). State ARARs include promulgated requirements under the state environmental or facility siting laws that are more stringent than federal ARARs, are uniformly applied in the state, and have been identified to EPA by the state in a timely manner. Subparagraph $121(\mathrm{~d})(2)(\mathrm{c})$ of CERCLA limits the applicability of state requirements or siting laws that could effectively result in the statewide prohibition of land disposal of hazardous substances, pollutants, or contaminants unless certain conditions are met.

Federal, state, or local permits are not needed for removal or remedial actions implemented on-site [Subsect. 121(e) of CERCLA]. "On-site" is interpreted to include the areal extent of contamination and all suitable areas in reasonable proximity to the contamination necessary for implementation of the response action. Soil or groundwater contamination has not been identified at the UNC Disposal Site.

A requirement may be either applicable or relevant and appropriate to a remedial action, but not both. An applicable requirement specifically addresses a hazardous substance, pollutant, contaminant, remedial action, location, or other circumstance at a CERCLA site. Relevant and appropriate requirements, while not "applicable," address problems or situations sufficiently similar to those encountered at a CERCLA site such that their use is well suited to the particular site (52 FR 32497, August 27, 1987). EPA makes the final determination on the applicability or relevance and appropriateness of a requirement based on such factors as the characteristics of the remedial action and the physical circumstances of the site. Generally, ARARs are applied equally.

In addition, other federal and state criteria, advisories, and guidances have been considered in developing the recommended cleanup levels and have been identified for consideration during the design phase of proposed remedial actions. These other documents are called "to be considered" (TBC) information. Although TBCs are not promulgated and 
do not have the same status as ARARs, they may be useful in establishing a cieanup level or in designing a remedial action.

There are three types of ARARs. The first type includes contaminant-specific requirements. These ARARs set limits on concentrations of specific hazardous substances, pollutants, and contaminants in the environment. Examples of this type of ARAR are ambient water quality criteria and drinking water standards. EPA has issued guidance on the use of water standards as chemical-specified ARARs (52 FR 3'2496-32499). This guidance was used as the basis for comparisons to predicted groundwater concentrations for the UNC Disposal Site. A second type of ARAR includes location-specific requirements that set restrictions on certain types of activities based on site characteristics. These include restrictions on activities in wetlands, floodplains, and historic sites. The third type of ARAR includes action-specific requirements. These are technology-based restrictions that are triggered by certain types of remedial actions (alternatives) under consideration. Examples of action-specific ARARs are Clean Water Act requirements for wastewater treatment and discharge.

The detail analysis of alternatives (Sect. 4.) will evaluate all applicable federal and state ARARs that apply to each remedial alternative.

\subsubsection{Chemical-Specific ARARs}

The Oak Ridge UNC Disposal Site contains 55-gal drums filled with sludge and soils, and boxes filled with contaminated solid waste. None of the contained waste has been identified as RCRA hazardous waste. In addition, there is no evidence of migration of the contained waste constituents to adjacent soil or groundwater. Therefore, there are no chemical-specific regulations that might be considered to be ARARs for cleanup of waste at this site.

Nitrate and strontium-90 have been selected as the contaminants of concern at the site. Although there is a potential for runoff from this site to impact adjacent surface water, there are no available federal or state ambient water quality criteria for these two contaminants.

Although there is no evidence of groundwater contamination at this time, modeling has predicted the potential for migration of nitrate and strontium- 90 to underlying soils at the site into groundwater if present site conditions (exposed excavation) are left as is (noaction scenario) (Sect. 1.2.5.6). In this event, cleanup of contaminated groundwater to Safe Drinking Water Act maximum contaminant levels (MCLs) would be considered relevant and appropriate if the groundwater may be used for drinking wate: purposes. The MCL for nitrate is $10 \mathrm{mg} / \mathrm{L}$ and for strontium-90 is $8 \mathrm{pCi} / \mathrm{L}$ (40 CFR 141.16).

Very few applicable standards are available for the cleanup of radioactively contaminated CERCLA sites. The Atomic Energy Act (AEA) of 1954 and its amendments 
delegated authority for control of nuclear energy to DOE, the U.S. Nuclear Regulatory Commission (NRC), and EPA.

EPA intends to develop environmental radiation protection standards for the disposal of low-level waste (LLW) under 40 CFR 193 and 764. The intent of these standards will be to protect the public health and general environment from potential adverse effects from LLW disposal. These proposed regulations may provide TBC guidance for cleanup of strontium-90 (Notice of Proposed Rulemaking intended September 1991; Final Rule, December 1992).

DOE is authorized to control all types of nuclear materials at sites under its jurisdiction and is exempt from the NRC licensing and regulatory requirements. Therefore, NRC regulations are not considered to be ARARs for CERCLA cleanup at DOE facilities; however, they provide TBC guidance for cleanup. DOE regulations for handling and cleanup of radioactive materials are outlined in a series of internal DOE orders that are legally binding to DOE contractors but are not considered by EPA to be ARARs. Therefore, for the purpose of development of ARARs, DOE orders will be treated, along with the NRC regulations, as TBC guidance.

As mentioned previously, DOE is not regulated by the NRC; however, NRC regulations might provide some TBC guidance for cleanup of strontium-90 at the UNC Disposal Site. The standards for protection against radiation (10 CFR 20) are designed to limit radiation exposures from NRC-licensed activities. They provide permissible worker exposure limits for restricted areas of $1.25 \mathrm{rem} /$ quarter (10 CFR 20.101) and radiation exposure limits to the general public in unrestricted areas of 500 millirem (mrem)/year (10 CFR 20.105). These resulations, included in 10 CFR 20, are being revised by the NRC, with a final rule expected February 1991.

10 CFR 61.41 states that concentrations of radioactive materials released to the environment in all media must not result in an annual dose exceeding $75 \mathrm{mrem}$ to the thyroid and 25 mrem to total body, or all other organs, of any member of the public. In addition, reasonable effort must be made to maintain releases of radioactive materials to "as low as reasonably achievable" (ALARA). As stated in 10 CFR 61.42, inadvertent intruders must be protected following cessation of active institutional controls, and 10 CFR 61.41 provides that operations at land disposal facilities must be carried out in compliance with 10 CFR 20.

DOE Order 5400.5 (Radiation Protection of the Public and the Environment, February 8, 1990) establishes radiation exposure limits for the general public as well as derived concentration guides for discharges of radioactively contaminated liquids to surface waters. These latter might provide guidance for the discharge of wastewater effluents as described in Alternative 3. The radiation exposure limits defined in DOE Order 5400.5 are an effective dose equivalent of $100 \mathrm{mrem} / \mathrm{year}$ from all exposure pathways and all DOE sources of radiation and a dose $<5 \mathrm{rem} / \mathrm{year}$ for a single acute exposure. The overriding 
principle of the DOE order is that all releases of radioactive material shall be ALARA. DOE Order 5820.2A (Radioactive Waste Management, September 9, 1988) states that the management of low-level radioactive waste must ensure that external exposure to the waste and concentrations of radioactive material that may be released into surface water and soil does not exceed 25 mrem/year for any member of the public. Releases to the atmosphere shall not exceed 10 mrem/year. Reasonable effort should be made to maintain releases to the environment to ALARA levals.

\subsubsection{Location-Specific ARARs}

The Fish and Wildlife Coordination Act as well as the Tennessee Water Quality Control Act may be triggered in the event that any site modifications, excavation, or other activities that are implemented during remediation would affect adjacent streams (Table 13).

The Tennessee Natural Areas Preservation Act (TCA 11-14-101) protects statedesignated reference areas (RAs). One such area, RA-14, Fanny Knob White Oak area, is adjacent to the UNC Disposal Site. This RA contains a state-listed threatened plant, Panax quinquefolius, the ginseng plant. Although it is considered unlikely to occur, site modifications that might affect this $\mathrm{RA}$ would trigger the above act, as well as the state endangered species act (TCA 70-8-101) (see Table 13).

Tennessee also has a cemeteries protection act (TCA 46-1-101 et seq.) (Table 13). It is unlikely that any modifications to Mt. Vernon Road will be necessary to accommodate increased vehicular traffic during remediation of this site. However, if there is a need to widen Mt. Vernon Road to facilitate movement of construction vehicles, the Act might be triggered.

There is no evidence of wetlands in the area of the UNC Disposal Site, nor is it in a 100- or 500-year floodplain. There are no federally listed endangered or threatened plants or animals at the site, nor are there any historical sites or evidence of archaeological findings.

\subsection{Action-Specific ARARs}

Action-specific ARARs are triggered by the particular remedial activities that are selected io accomplish a remedy. Certain ARARs represent hybrids between chemical-, lo:ation-, and action-specific ARARs. These hybrid ARARs involve an action taken with respect to a specific constituent or location. Effluent discharge limits or air emission standards are considered hybrids between action-specific and chemical-specific ARARs because an action (i.e., a discharge) is taken with respect to a chemical.

CERCLA on-site remedial response actions must only comply with the substantive requirements of a regulation and not the administrative requirements to obtain federal, state, or local permits [CERCLA \$121(e) and the Federal Facilities Agreement (FFA) \$XXII]. 

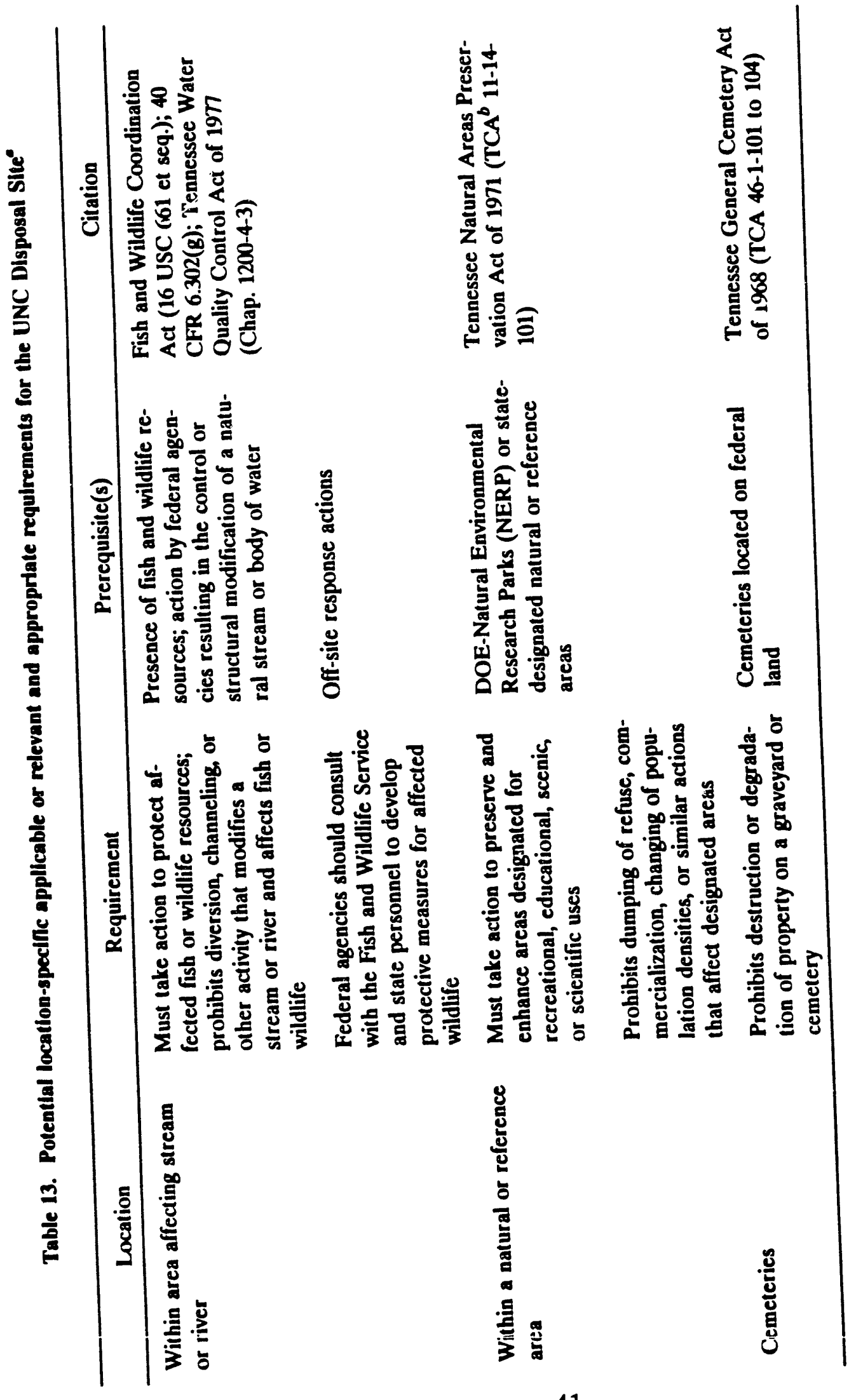

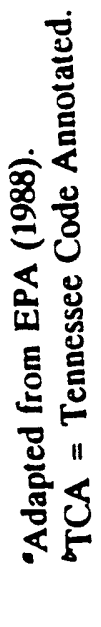


To ensure that CERCLA response actions proceed as rapidly as possible, EPA has reaffirmed this position in the final National Contingency Plan (NCP) (55 FR 8756, March 8, 1990). Substantive requirements pertain directly to the actions or conditions at a site, whereas administrative requirements facilitate their implementation. However, although the UNC Disposal Site is considered a CERCLA site, there is the possibility that state permitting (e.g., NPDES and air emissions) for the treatment alternative may be required.

Since the UNC Disposal Site is not a RCRA-permitted facility and does not contain any RCRA-listed hazardous or characteristic waste, none of the RCRA land disposal restrictions are considered to be ARARs. In addition, none of the RCRA Subtitle C Hazardous Waste Management regulations will be legally applicable to remediation at this site. However, since remedial actions developed for this site are similar to RCRA actions, the RCRA regulations may be considered to be relevant and appropriate for cleanup.

The general remedial response acticns (Sect. 4) selected for the UNC Disposal Site include (1) no-action/institutional, (2) control/containment, (3) treatment, and (4) disposal. There are no action-specific ARARs applicable to the no-action alternative. Action-specific ARARs for potential general remedial responses are provided in Tables 14 through 16. Regulations pertinent to each specific alternative will be discussed in detail in the analysis of alternatives.

\subsubsection{On-site construction/excavation}

Certain on-site construction and/or excavation activities may be necessary to prepare the site for remediation. These might include the development of additional roads for vehicular traffic, movement of soils, site grading, or site cleaning activities. Table 14 lists ARARs for these activities.

Airborne pollutants may result from these construction activities. The primary concern is elevation of particulate concentrations resulting from earth-moving and sitegrading activities. Nonpoint source contributions to fugitive dust emissions are regulated by the Clean Air Act (40 CFR 50). The National Ambient Air Quality Standard (NAAQS) for particulates is $75 \mu \mathrm{g} / \mathrm{m}^{3}$ (annual geometric mean) and $260 \mu \mathrm{g} / \mathrm{m}^{3}$ as a maximum 24-hour concentration not to be exceeded more than once per year ( 40 CFR 50.6).

The Tennessee Department of Health and Environment (TDHE), Division of Air Pollution Control, has also promulgated regulations governing fugitive dust emissions [Tennessee Code Annotated (TCA) 1200-3-8-.01]. These are listed in Table 14 and are applicable to remedial activities at the UNC Disposal Site.

\subsubsection{Surface watis control}

Surface waters in the vicinity of the construction site will need to be monitored to identify potential impacts from this nonpoint source (construction) activity. The relevant 


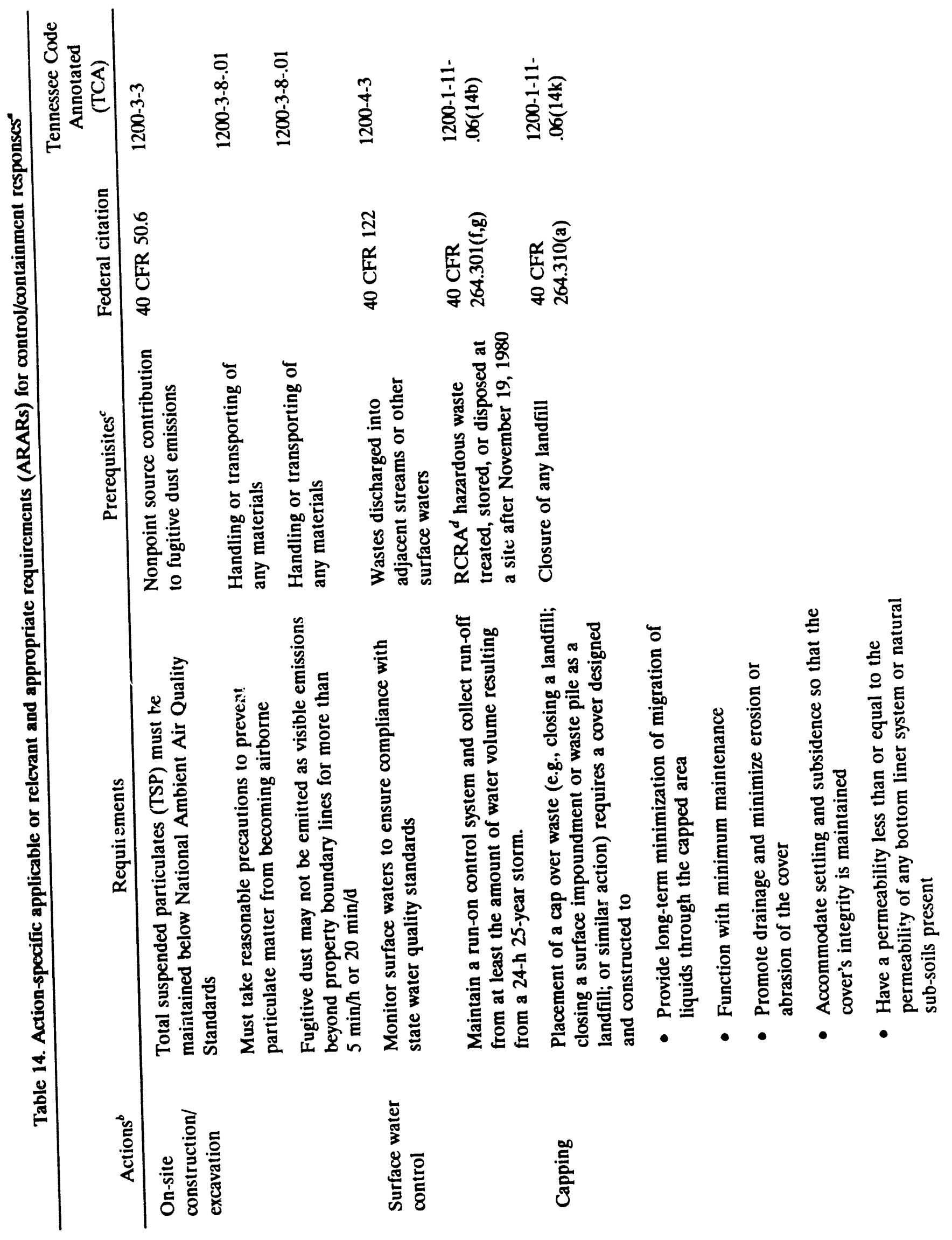




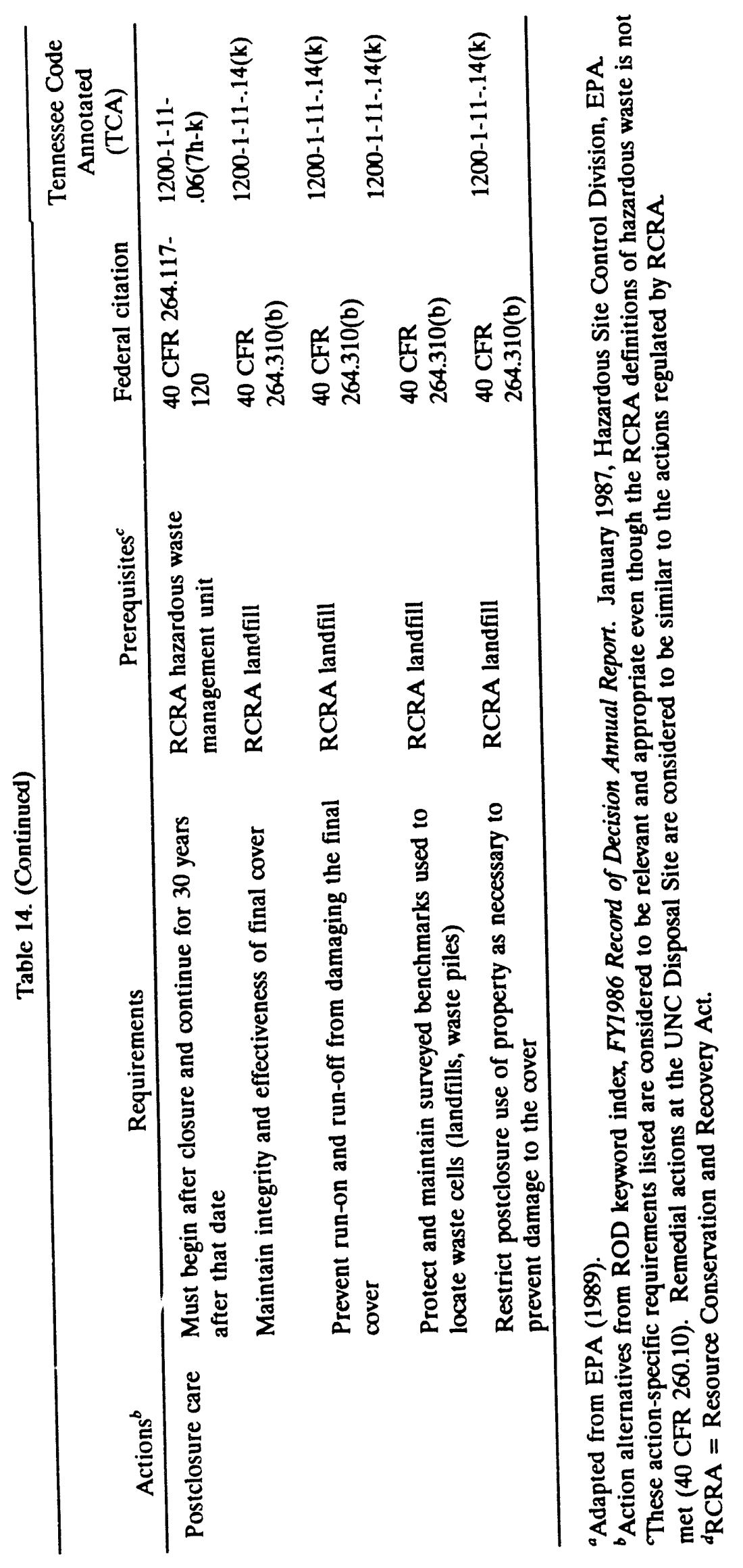




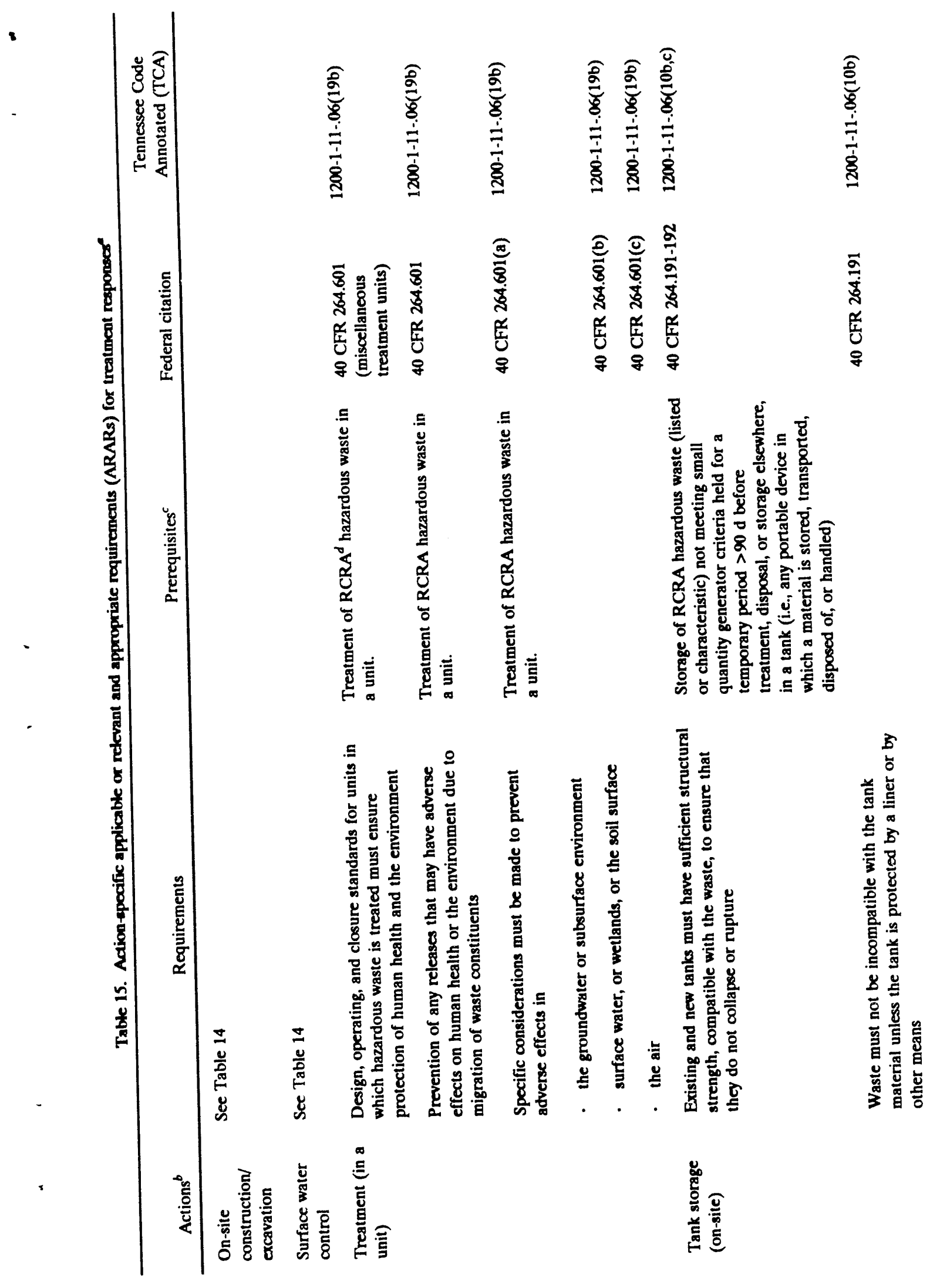









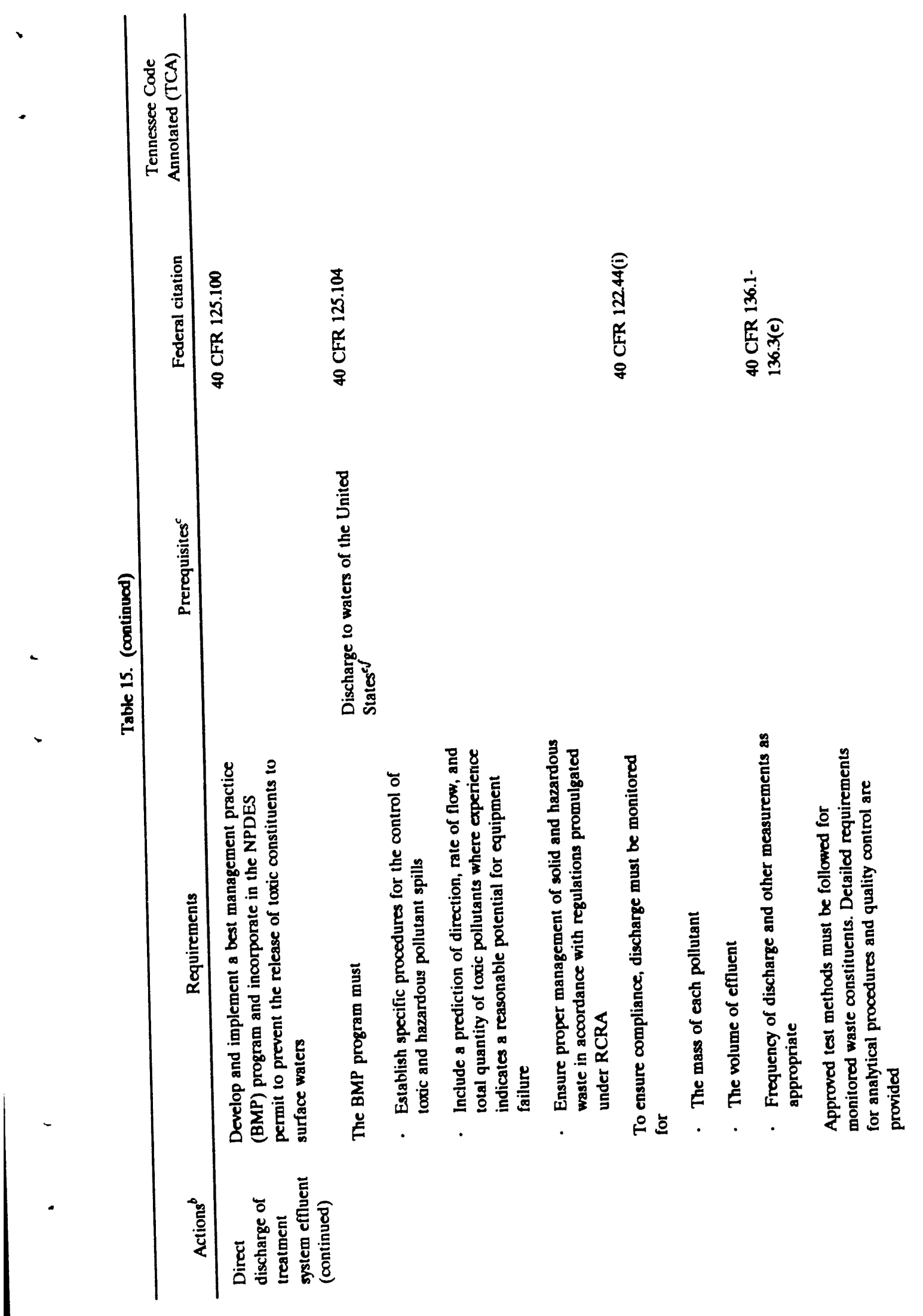




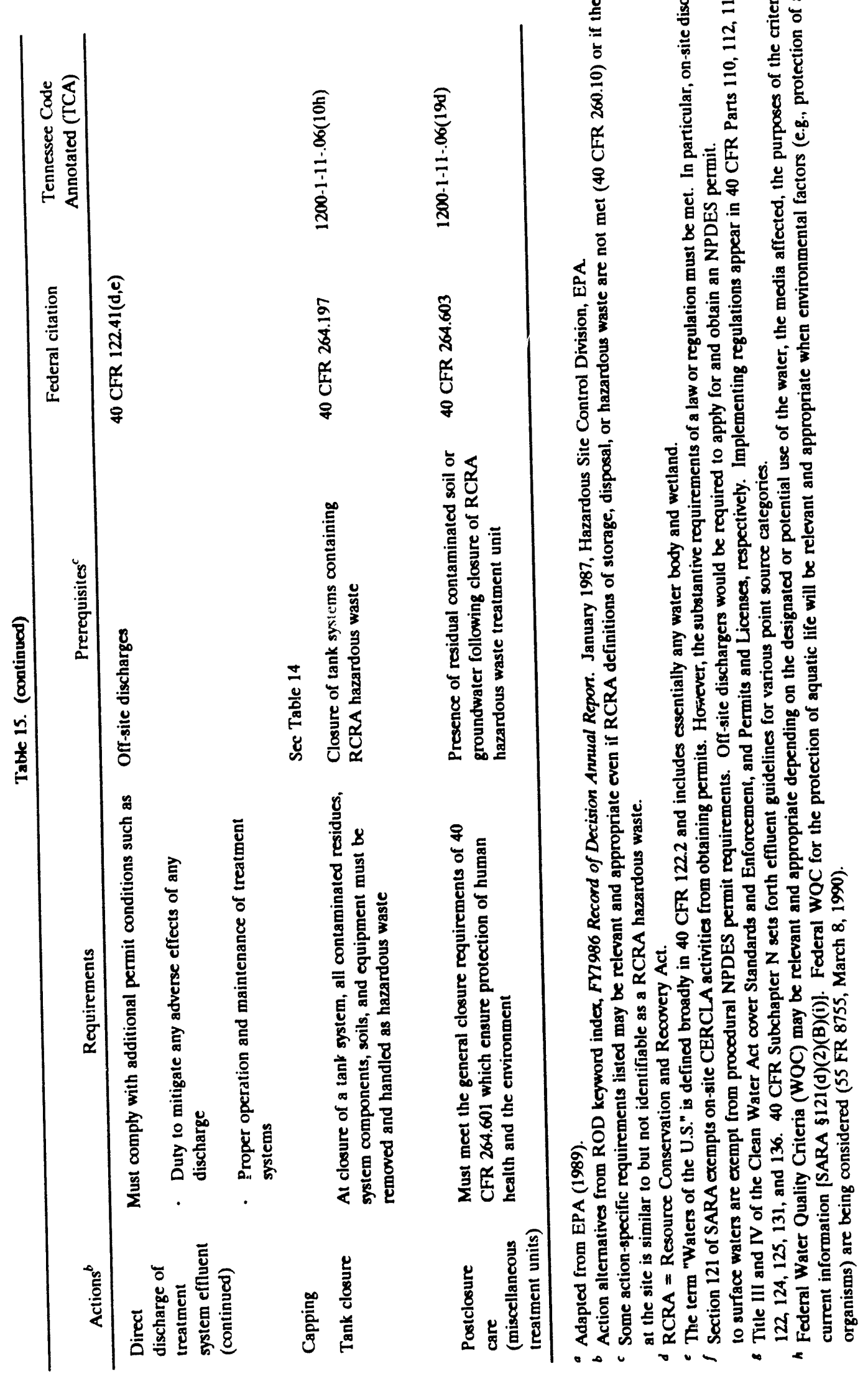







monitoring parameters for such activities are listed in TCA 1200-4-3-.03 and include total dissolved solids, dissolved oxygen, $\mathrm{pH}$, and temperature. The National Pollutant Discharge Elimination System (NPDES) permit program includes applicable effluent standards, monitoring requirements, and conditions for discharge (40 CFR 122). Tennessee has an EPA-authorized state program that is equivalent to the federal program (TCA 69-3-108 et seq.). A run-on and run-off control system must be maintained at the site (40 CFR 264.301, TCA 1200-1-11-.06).

\subsection{CONTAMINANTS OF INTEREST AND REMEDIAL ACTION CRITERIAVGUIDANCE}

In summary, various federal and state of Tennessee regulatory documents were researched to identify target levels for ARARs for potential contaminants migrating from the drummed soils/sludges and miscellaneous scrap. No groundwater or soil contamination has been identified. However, based on their high concentration in the source material, nitrate and strontium-90 have the potential of affecting groundwater and surface water. The basis for the ARARs includes the Safe Drinking Water Act MCLs.

The remedial target levels are based on reducing the concentration of nitrate and strontium-90 potentially migrating to groundwater to below MCLs. The risks to human health and the environment due to exposure to groundwater following remedial actions will be evaluated by analyzing residual contaminant concentrations following a reduction of contamination to remedial target levels.

Various action-specific ARARs are pertinent to the implementation of the remedial alternatives and will be addressed in the detailed analysis of each alternative.

\subsection{SOURCE CONTROL OBJECTIVES}

In general, the objectives for source control actions include (1) preventing or mitigating releases of contaminants to surrounding environmental media and (2) eliminating or minimizing the threat to public health and environment from the source material itself.

The first objective, preventing or mitigating release of contaminants to the surrounding environment, involves assessment of migration pathways for the contaminants of concern. The primary exposure or transport pathway is the downward movement of the contaminants from the drummed soil/sludges into the groundwater and surface water.

Three general types of source control actions can be implemented to reduce releases of contaminants:

1. isolate the source area to eliminate transport pathways,

2. reduce contaminant levels in the source (via treatment), and 
3. remove the source area altogether (to isolation or treatment facilities).

The potential transport pathways to groundwater are primarily the infiltration of precipitation through the exposed drummed sludge/soil to the unsaturated zone of the soil, with subsequent leaching and transport of contaminants to the groundwater. Surface runoff is a potential contaminant migration mechanism at the UNC Disposal Site, which would also affect the local soil and groundwater. No soil or groundwater contamination, however, has been identified at the site.

The second objective, eliminating or minimizing the threat posed to public health or the environment from the UNC Disposal Site, involves addressing exposure pathways, receptor populations, and levels of exposure. Human exposure risks are minimal because the site is isolated from the public (secured area) and personnel at the Y-12 Plant are not normally in contact with the site.

Future human and wildlife exposure at the UNC Disposal Site is expected to be minimal due to continued institutional control. The potential impacts of each remedial action on long-term land use are examined during alternatives development and screening in Chap. 3. Potential human exposure would essentially be limited to construction workers for the duration of remedial and corrective actions.

In summary, the potential for direct exposure to contamination from sources at the UNC Disposal Site is minimal. Target levels for source control have been developed considering migration of contaminants from the drummed sludges/soil to surface water or soil and subsequently to the groundwater as the primary exposure route of concern. Hypothetical exposure to contaminated groundwater (based on models) is the basis for establishing acceptable levels of contaminants in groundwater.

Source control actions are presented in accordance with the requirements of NCP. Based on source control actions, the following types of alternatives will be developed to the extent practicable:

1. an alternative that would minimize the need for long-term management;

2. an alternative that would use treatment as a principal element to reduce contaminant levels in the source;

3. an alternative that involves containment of materials with little or no treatment, but provides protection of huma.: health and the environment by preventing exposure and/or by reducing the mobility; and

4. a no-action alternative. 


\subsection{OTHER CONSIDERATIONS}

\subsubsection{Innovative Technologies}

EPA guidance specifies that careful consideration be given to the use of innovative and advanced technologies aimed at recycle/reuse, waste minimization and degradation, or destruction of contaminants on-site. The level of detail presented in this report, with regard to these technologies, is limited; and detailed evaluation of these technologies is difficult without the results of pilot studies. For the purpose of this portion of the FS, technologies are included in a given alternative if they are theoretically applicable, could potentially achieve the desired objectives, or if sufficient laboratory and field studies have been conducted to enable development of a treatment process for use in a pilot study. The issue of long-term reliability as a criterion for the alternatives is addressed by giving preference to innovative or advanced technologies that use conventional equipment or processes or simple equipment and process controls to minimize operational upsets. This decision is applicable to treatment processes in particular.

\subsubsection{NEPA Considerations}

The National Environmental Policy Act (NEPA) requires an environmental review of all proposed actions that involve the expenditure of federal funds. In December, 1989 the Y-12 Plant was placed on NPL, and EPA directed DOE-ORO to comply with CERCLA requirements for closure of the UNC Disposal Site at the Y-12 Plant. DOE has proposed guidelines that incorporate NEPA requirements into the CERCLA process (Levine et al. 1989). Included in this feasibility study are the consideration, evaluation and comparison of the proposed remedial alternatives. NEPA requirements for remedial alternatives resulting from the screening process are discussed in Sect. 4.

\subsection{GENERAL RESPONSE ACTIONS}

General response actions for the drummed soils/sludges and miscellaneous scrap at the UNC Disposal Site are shown in Table 17. General response actions represent the universe of technologies that have the potential to satisfy the remedial response objectives developed in this portion of FS. General response actions shown in Table 17 include noaction/institutional actions, containment, treatment, and disposal. Actions that have demonstrated success in the containment, treatment, and disposal of contaminated materials are included, as well as actions that are considered new and emerging. A variety of response actions is presented so that remediation planning is not unnecessarily restricted during refinement stages of FS.

For each general response action shown in Table 17, there exists at least one technology as a response. For each technology, there exists at least one process option. Combinations of process options and technologies will be used when developing alternatives for remediating drummed soil/sludges and boxes of miscellaneous scrap. 


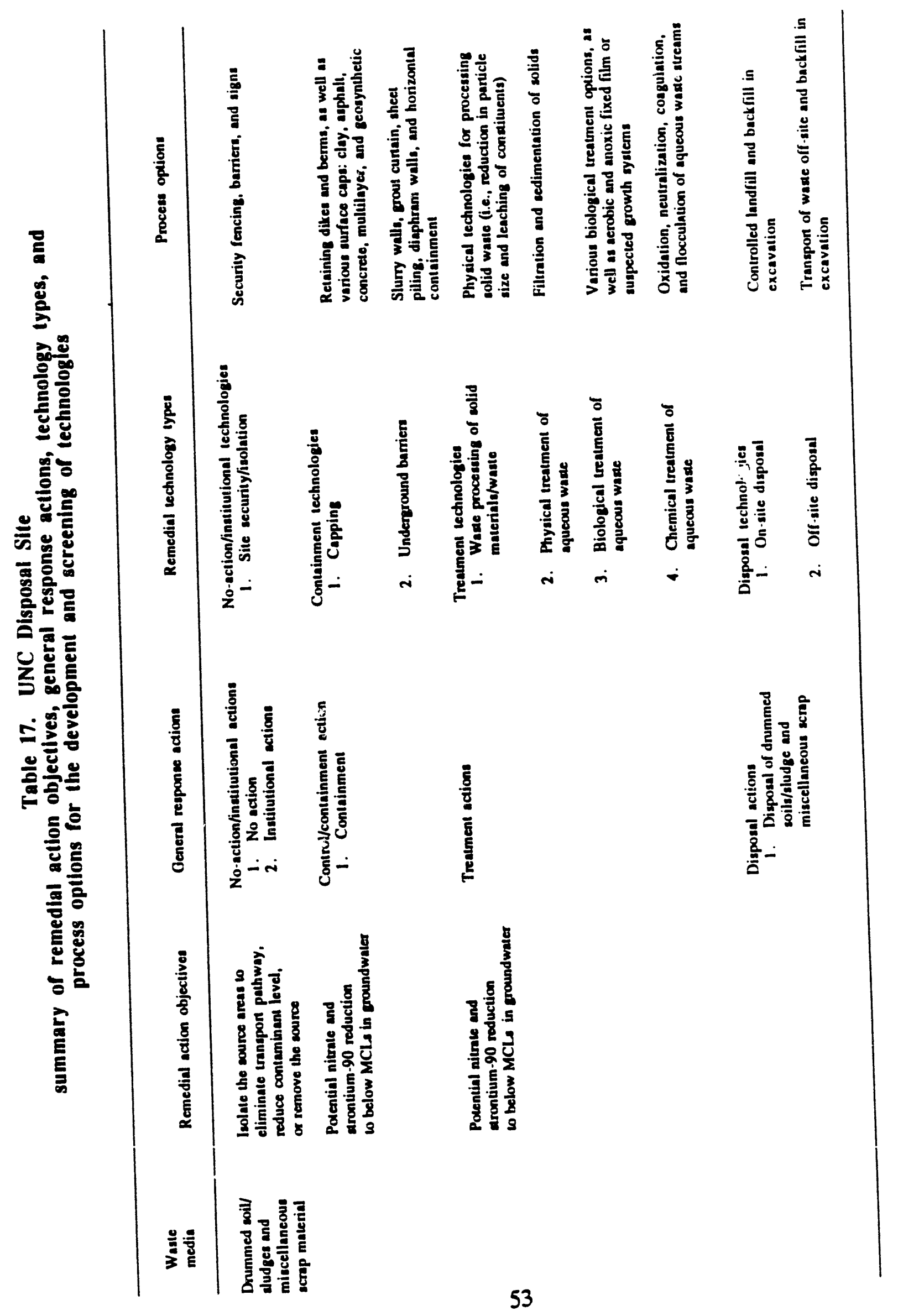




\section{INITIAL SCREENING, EVALUATION, AND SELECTION OF TECHNOLOGY TYPES AND PROCESS OPTIONS}

This section presents the initial screening of response actions, technologies, and process options whereby the universe of items is reduced based on general applicability. The actions, technologies, and process options passing screening are subsequently evaluater with regard to effectiveness, ease of implementation, and relative costs. The actions, technologies, and process options that receive favorable evaluation are then selected for combination into alternatives.

\subsection{INITIAL SCREENING}

The purpose of the initial screening step is to eliminate general response actions, technologies, or process options that are inappropriate for contaminants or site conditions at the UNC Disposal Site. That is, the eliminated items do not provide a permanent means by which to prevent or minimize the release of substances of concern or cannot be implemented as a result of conditions at the site.

The criteria used in the initial screening step follow:

1. the compatibility of a treatment process with the contaminants of concern,

2. the long-term durability of the remedy,

3. the volume and character of wastes generated by the process, and

4. cost.

When two or more processes can be used to achieve the same result (i.e., capping) but at a substantially different cost, the most economical process is carried through.

A no-action/institutional action general response is included in the initial screening. This alternative provides the baseline against which other responses can be compared. An analysis of the no-action response is required under NCP.

The hierarchy of source control responses, technologies, and options is shown in Table 18, which is presented as a flowchart to facilitate the screening process. The table is formatted such that for each of the general response actions, different remedial technology types and various process options have been listed. A brief description of each option is provided, along with comments concerning elimination or selection for subsequent evaluation. The screening of remedial technologies for source control is based on the characterization of contaminants that have been detected in the wastes at the UNC Disposal Site. As shown in Table 18, the general response actions have been combined to yield four 


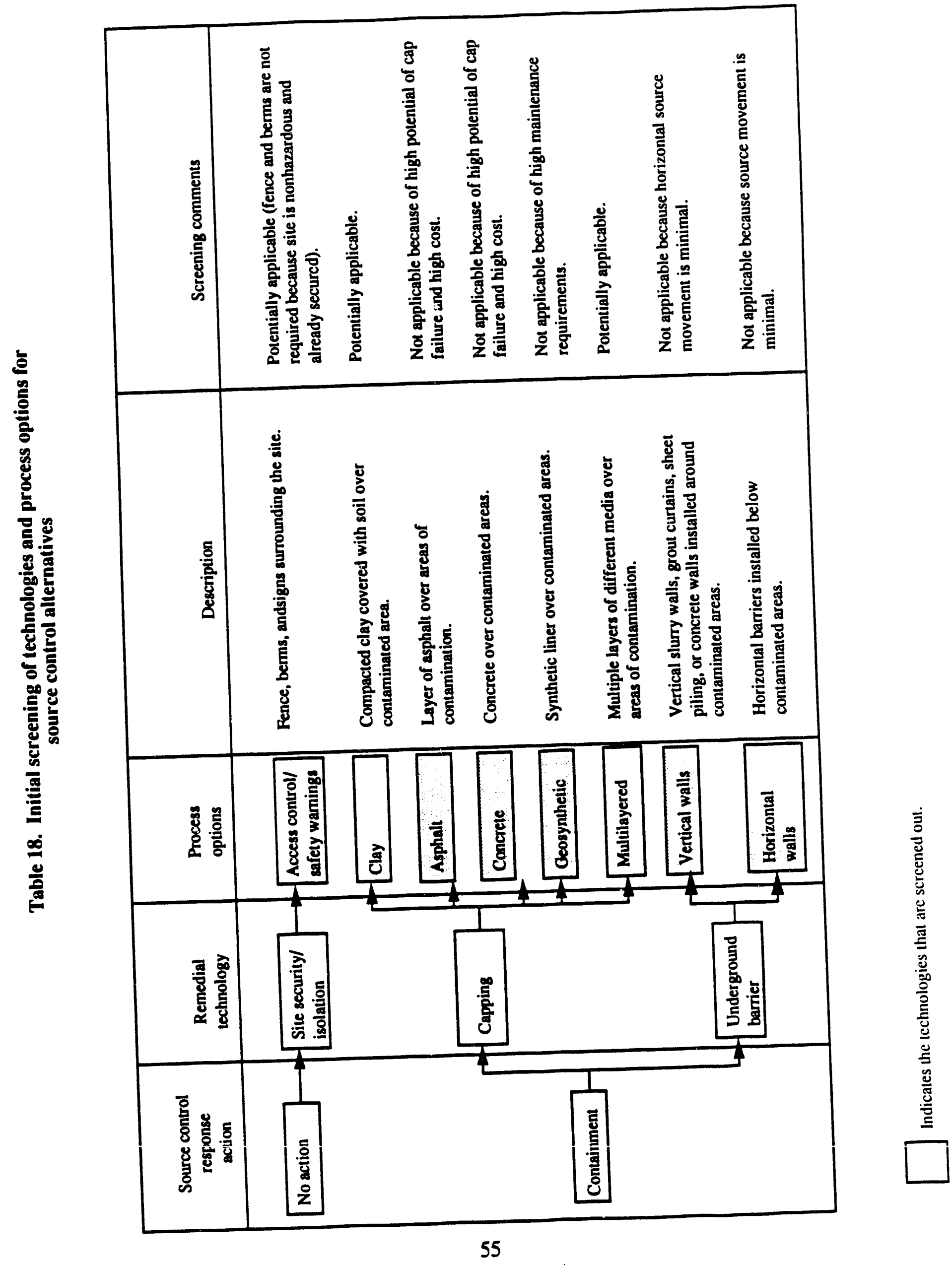



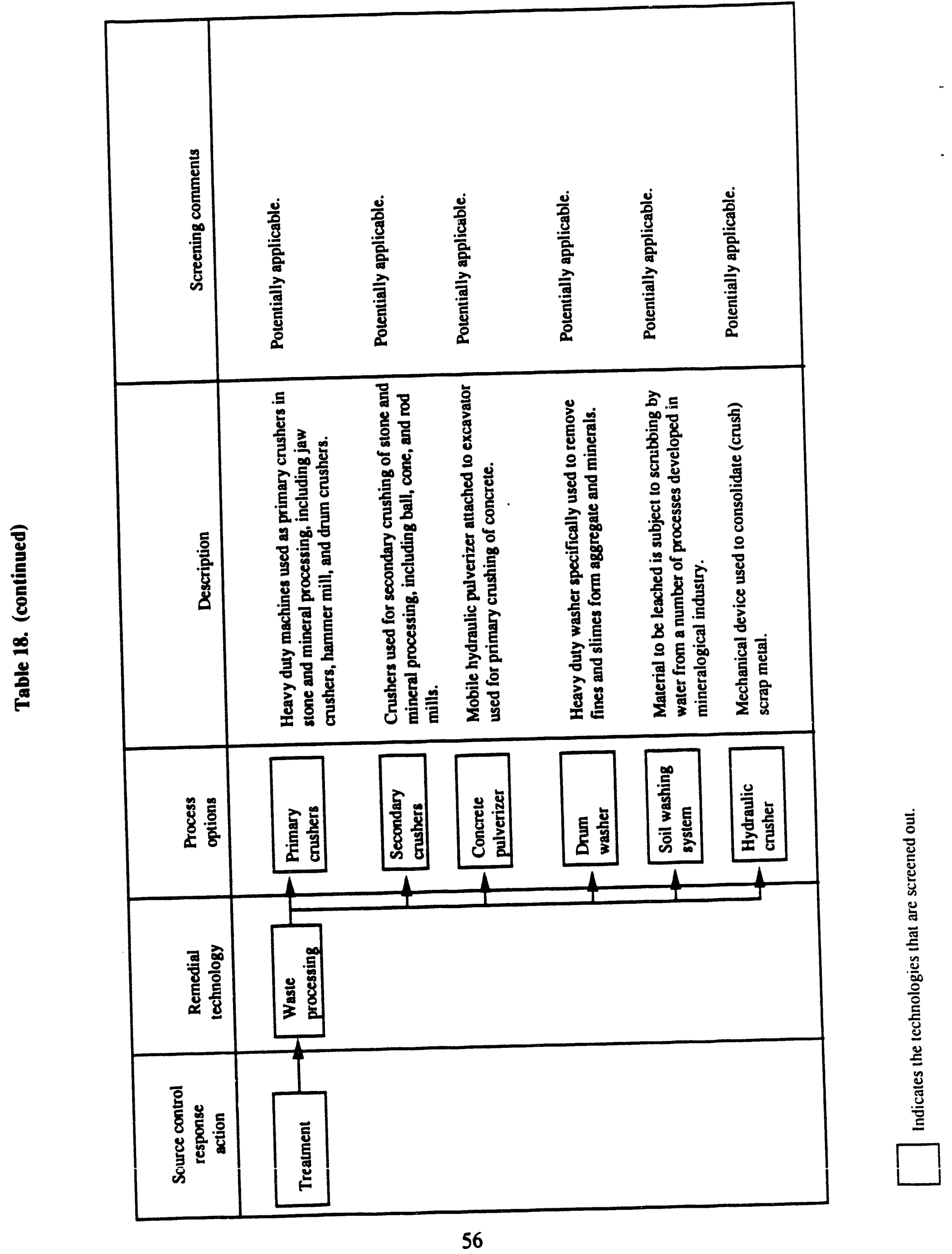

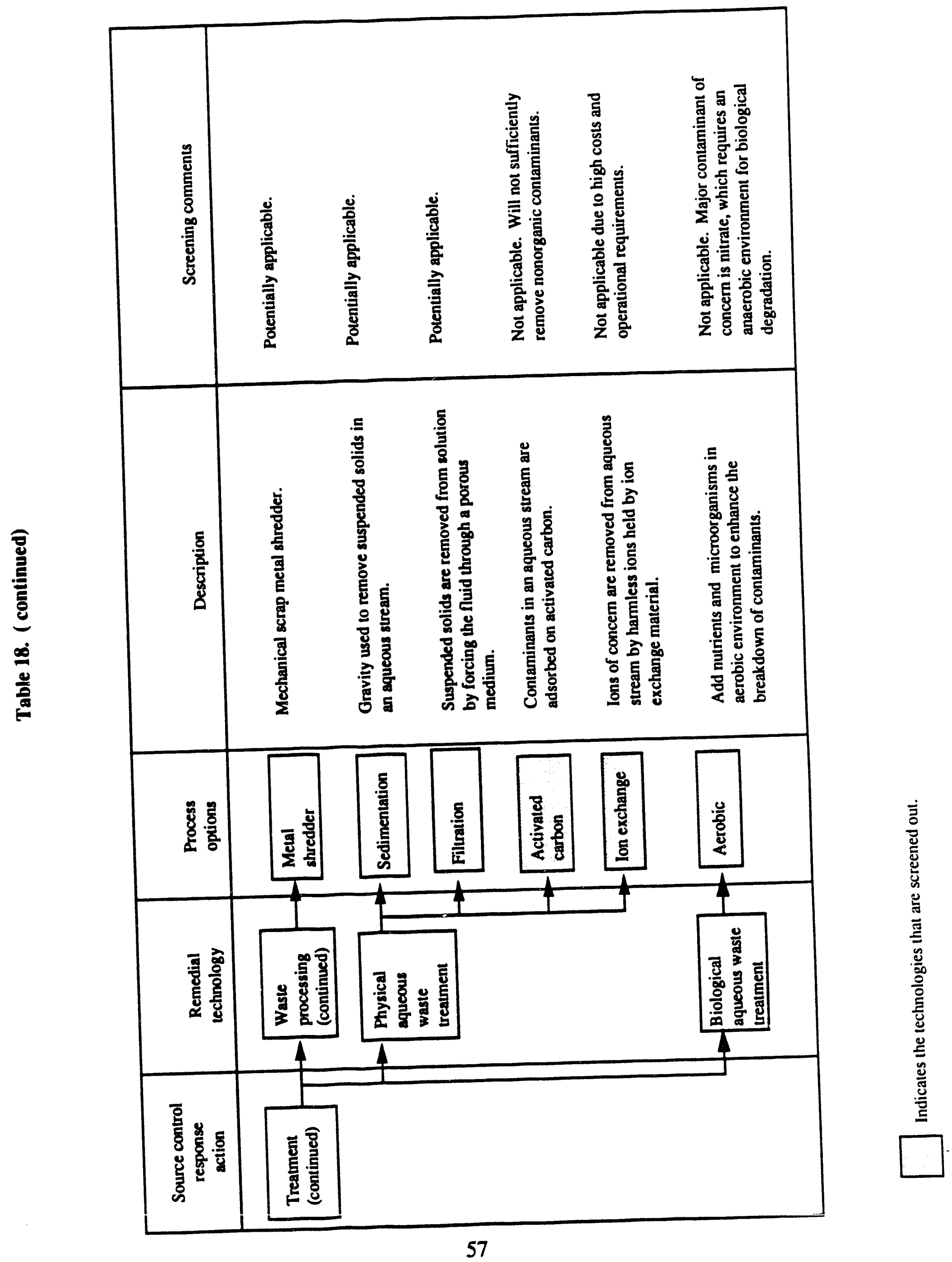

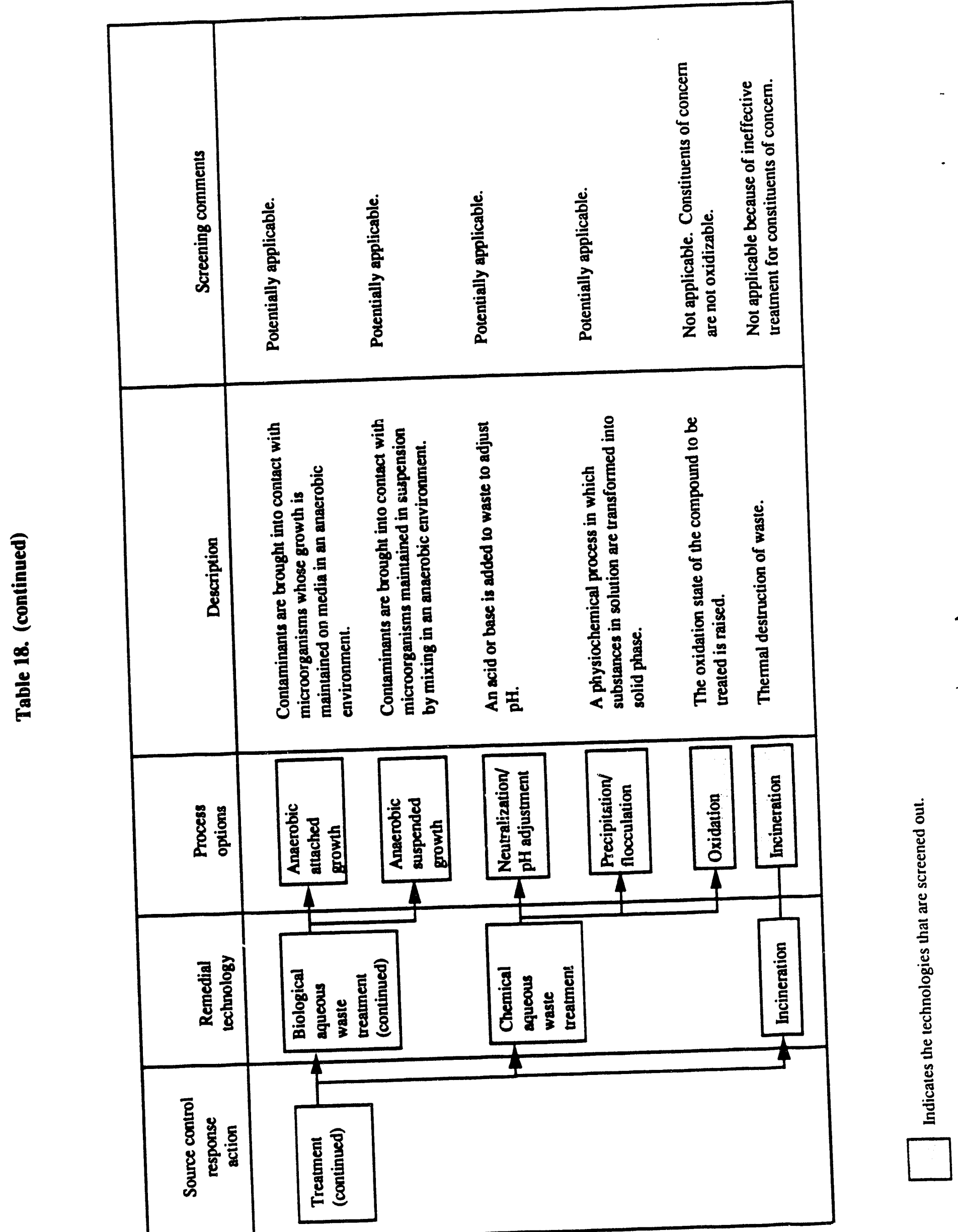

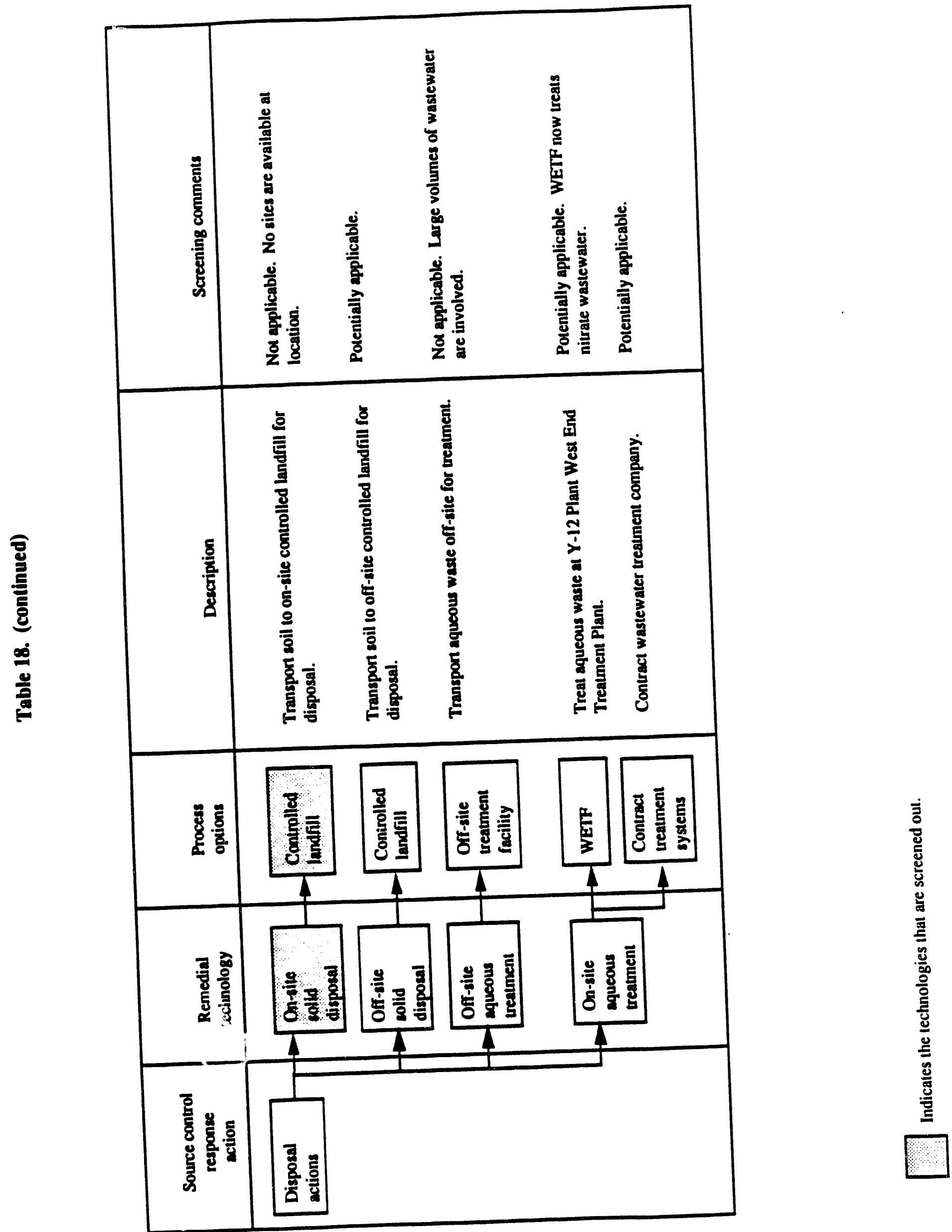
general responses to address the wastes at the UNC Disposal Site: no action/institutional action, containment, treatment, and disposal.

\subsubsection{No Action/Institutional Action}

This response provides the baseline against which other responses can be compared. This alternative allows sites to remain in their present condition with no active steps beyond those now being taken toward remediation.

\subsubsection{Containment}

The containment response allows the drummed soils/sludges and miscellaneous scrap material to be secured in place through capping and underground barrier technology. Capping with a durable soil and/or a synthetic cover mitigates the spread of contaminants by surface water. Lateral migration may be controlled through underground barriers, such as grout walls, sheet pile walls, etc. Containment reduces surface water infiltration, vertical migration of precipitation to groundwater, and direct contact of water with wastes. Several types of caps are available for use and include

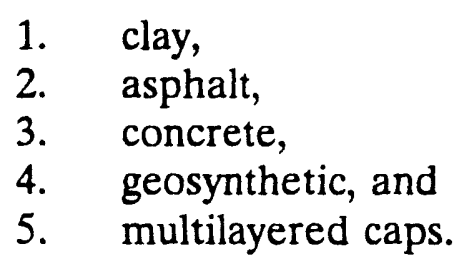

Asphalt and concrete caps were screened out because they have the highest potential to be damaged by solution cavity collapse and are not cost effective. Single-layer geosynthetic cap was screened out because of high potential maintenance. Multilayered and clay caps are potentially applicable beciuse both have been used at the Y-12 Plant Site and have the best structural integrity with regard to site characteristics. Clay is readily available on-site for both types.

Underground barrier technologies, in combination with capping, were eliminated because no vertical or horizontal migration of contaminants has occurred.

\subsubsection{Treatment}

The 11,000 drums of sludge (3520 $t$ ) account for $99 \%$ (Table 3) of the nitrate (52.4 $t$ as nitrogen). The $1 \%$ nitrate in the 18,000 drums of soil is insignificant and does not require treatment. Miscellaneous demolition materials do not represent a significant nitrate source and are not considered for treatment. Only the drummed sludges are being considered for processing for nitrate removal. 
Treatment (elimination) of contaminants of concern in the drummed sludges would prevent any future migration and contamination. As discussed in Sect. 2.1, treatment is preferred as a permanent remedy (according to NCP guidelines) to prevent or minimize migration of substances from the source material. Treatment of the drummed sludges requires a number of potential technologies and process options to be combined into a process stream. Nitrate, the main contaminant of concern, can be easily treated in an aqueous stream. Solid waste processing of the drummed sludges would be required to leach nitrate from the solidified sludges into an aqueous stream. Incineration was eliminated because it is not effective for constituents of concern (nitrate and strontium-90) in the waste.

\subsubsection{Waste processing}

Solid waste processing of a concrete cylinder measuring $-24 \times 36$ in. requires technologies developed for the mining industry. These technologies include primary and secondary crushing to reduce the material to a size that optimizes leaching of nitrates by water. Primary crushers are large, heavy-duty crushers used to reduce large material to a size ( $<9$ in.) sufficient for further processing by a secondary crusher.

Secondary crushers are used to reduce waste to the finer size required for efficient leaching. Reduction to sand-size fraction is possible with proper screening.

Washing and leaching an aggregate or mineral is accomplished using cylindrical drum washers. The material to be cleaned is rotated with water in a large drum with archimedesscrew baffles. The water in contact with the substrate cleans the material, and some leaching of contaminants occurs. Soil washing systems which are specifically designed to remove contaminants from a soil-like material are available. The system combines a number of mineralogical processing steps to wash and leach contaminants aggressively.

Hydraulic metal crushers or met. shredders will be necessary to reduce the volume of the empty drums and the scrap metal. Shredding and compaction reduce void spaces and the volume of empty drums, allowing more efficient handling and making them more amenable to further waste processing and disposal.

\subsubsection{Physical aqueous treatment}

A number of physical treatment technologies may be necessary as steps in the wastewater treatment process. Physical wastewater treatment removes constituents of concern (suspended and dissolved solids) using processes based on physical characteristics of the contaminants (specific gravity and particle size). Ion exchange was eliminated because it requires a high-quality influent water and has high operation oversight requirements. Activated carbon is most effecive in removing organic constituents but not inorganic constituents, such as nitrate and metals. 


\subsubsection{Biological aqueous treatment}

A high-nitrate aqueous stream will result from the solid waste processing. Anaerobic biological treatment can effectively and cheaply degrade nitrate in an aqueous stream. Aerobic biological processes are not particularly effective for the contaminants of concern and were eliminated. Both fixed film and suspended growth anaerobic technologies can effectively degrade nitrate.

\subsubsection{Chemical aqueous treatment}

A number of chemical treatment processes may be necessary in the aqueous treatment of the nitrate wastewater. Oxidation is eliminated because nitrate cannot be further oxidized; therefore, the process is ineffective.

Neutralization/pH adjustment may be required at more than one point in the treatment process. To meet NPDES discharge requirements or to achieve optimum performance of chemical treatment (coagulation/flocculation), $\mathrm{pH}$ adjustment may be necessary. Precipitation/flocculation is a physical/chemical process to remove dissolved or suspended solids and may be required.

\subsubsection{Disposal}

Disposal actions are applicable for both the solid materials at the UNC Disposal Site and wastewater generated from the physical (nitrate leaching) waste treatment. Site limitations at the Y-12 Plant eliminate transport of solid materials to an on-site controlled landfill; therefore, this technology is screened out.

Off-site solid disposal, although not a preferred technology, is carried through based on response action requirements and to offer an alternative requiring little future maintenance. This technology meets the screening criteria; however, restrictions on off-site shipments place limitations on what type of materials may be removed from the Y-12 Plant.

On-site aqueous wastewater treatment can be performed at the Y-12 Plant West End Treatment Facility (WETF) or by a contract wastewater treatment service. A number of firms have mobile treatment systems that can be brought to the site.

\subsection{RESULTS OF SCREENING FOR SOURCE CONTROL}

The following source control options meet the initial screening criteria:

1. no action/institutional action response (site security/isolation);

2. containment (clay cap and multilayered cap); 
3. treatment and solid waste processing (primary crushers, secondary crushers, drum washers, soil washing system, metal shredder, hydraulic compactor, and drum compactor);

4. physical aqueous waste treatment (sedimentation and filtration);

5. biological aqueous waste treatment (anaerobic fixed film and anaerobic suspended growth);

6. chemical aqueous waste treatment (precipitation/flocculation and neutralization/ $\mathrm{pH}$ adjustment);

7. disposal (off-site solids disposal and on-site aqueous disposal, including WETF and contract treatment service).

\subsection{EVALUATION OF PROCESS OPTIONS AND SELECTION OF REPRESENTATIVE PROCESSES}

This section evaluates, selects, and briefly describes the subset of process options that passed the initial screening in Sect. 3.1. Evaluation ensures that process options meet certain effectiveness, feasibility, and cost criteria. An optimal process representing each technology is then selected and briefly described. More than one process option, however, may be chosen to represent a technology if the options have sufficiently different performance capabilities or effects. This evaluation and selection process ensures simplification of the subsequent development and assembly of remedial action alternatives without limiting flexibility.

\subsubsection{Evaluation Criteria}

Process options are evaluated using three criteria:

1. effectiveness: The effectiveness of an option, relative to other processes within the same technology, is evaluated on the basis of its ability to handle the estimated areas or volumes of contaminated media; to protect human health and the environment during construction and implementation; to demonstrate reliability in relation to the contaminant(s) of concern; and to meet the response action objectives.

2. ease of implementation: The ease of implementation of an option is based on the technical and institutional feasibility of design, construction, and operation.

3. cost: The cost of an option at this stage of the FS process is based on relative capital and operation and maintenance (O\&M) costs. The costs of process options are relative to each other within a media grouping. 
In the evaluation step, effectiveness is the primary concern, with less emphasis placed on ease of implementation and costs. Process option evaluation for the drummed soils/sludge and miscellaneous scrap is presented in Table 19. The table presents the options that passed initial screening in Sect. 3.1, along with the associated technologies and responses. The evaluation is conducted as a flowchart with separate sections for comments on effectiveness, ease of implementation, and cost.

\subsubsection{Selection Criteria}

Representative processes are selected to develop a subset of options that provide the highest degree of remedial performance in relation to the drummed soil/sludges and miscellaneous scrap. Usually one process is chosen to represent each technology type. The representative options are selected based on the relative ratings each attained under the evaluation criteria. As in the evaluation step, effectiveness is the primary consideration, with implementability and cost having less importance. This emphasis ensures that health and environmental factors dictate the development of remedial action alternatives. Although the representative selection process provides a basis for preliminary alternative design, the final selection of a specific process or processes used during remedial action implementation may not occur until the remedial design phase. Selected processes for source control are highlighted in Table 19.

\subsubsection{Description of Selected Process Options for Source Control Alternatives}

This section briefly describes the process options selected for combination into source control alternatives. The evaluation and selection of source control technologies and process options are presented in Table 19.

\subsubsection{No-action response}

The technology type selected for the no-action response for source control consists of site security and safety/warning signs. The site is now and will remain a secured site. Additional safety/warning signs around the perimeter of the site may be necessary. This option reduces the chance of direct contact with the contaminated media but does not adequately address the problem of mobility, concentration, and volume reduction of contaminants. The process is easily implemented; furthermore, it has low capital costs and very low O\&M costs.

\subsubsection{Containment response}

Multilayer or multimedia capping is the selected process option for source control through containment. Multilayer caps, due to their composite design and high structural integrity, are less susceptible to natural or accidental damage. Multilayer caps have inherently greater strength and stability than other caps and are less likely to fail from solution cavity collapse or other natural phenomena. This process option essentially 


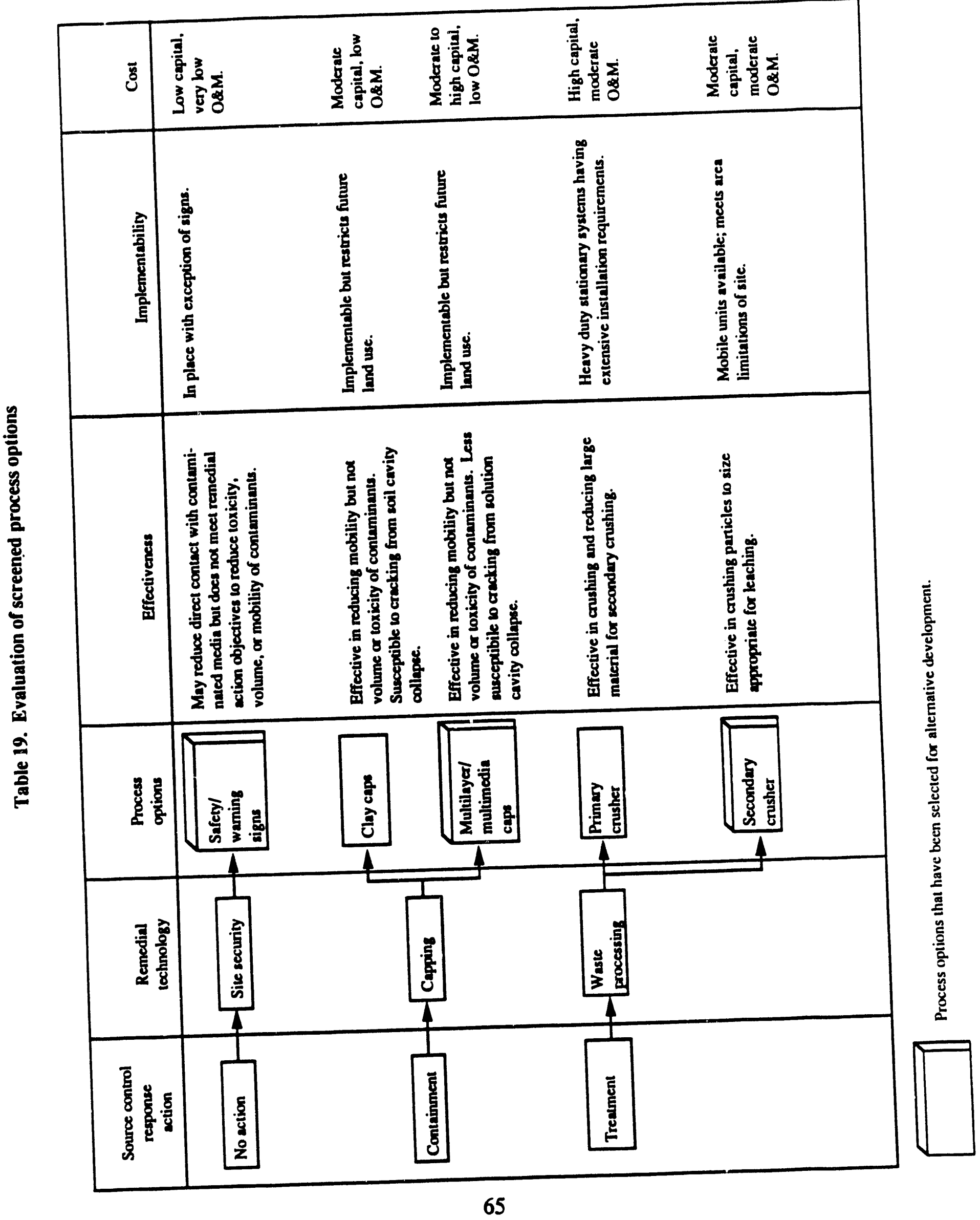



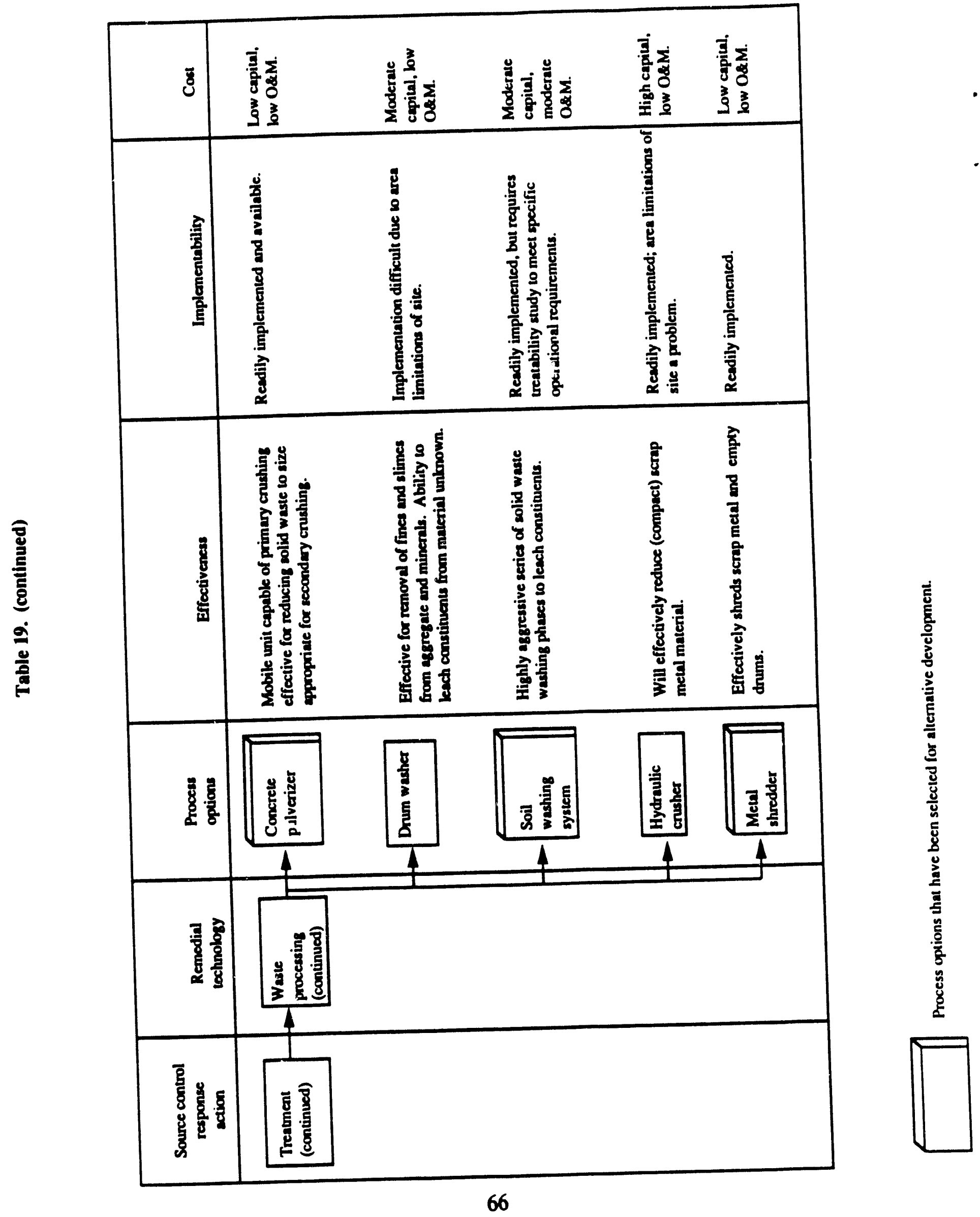

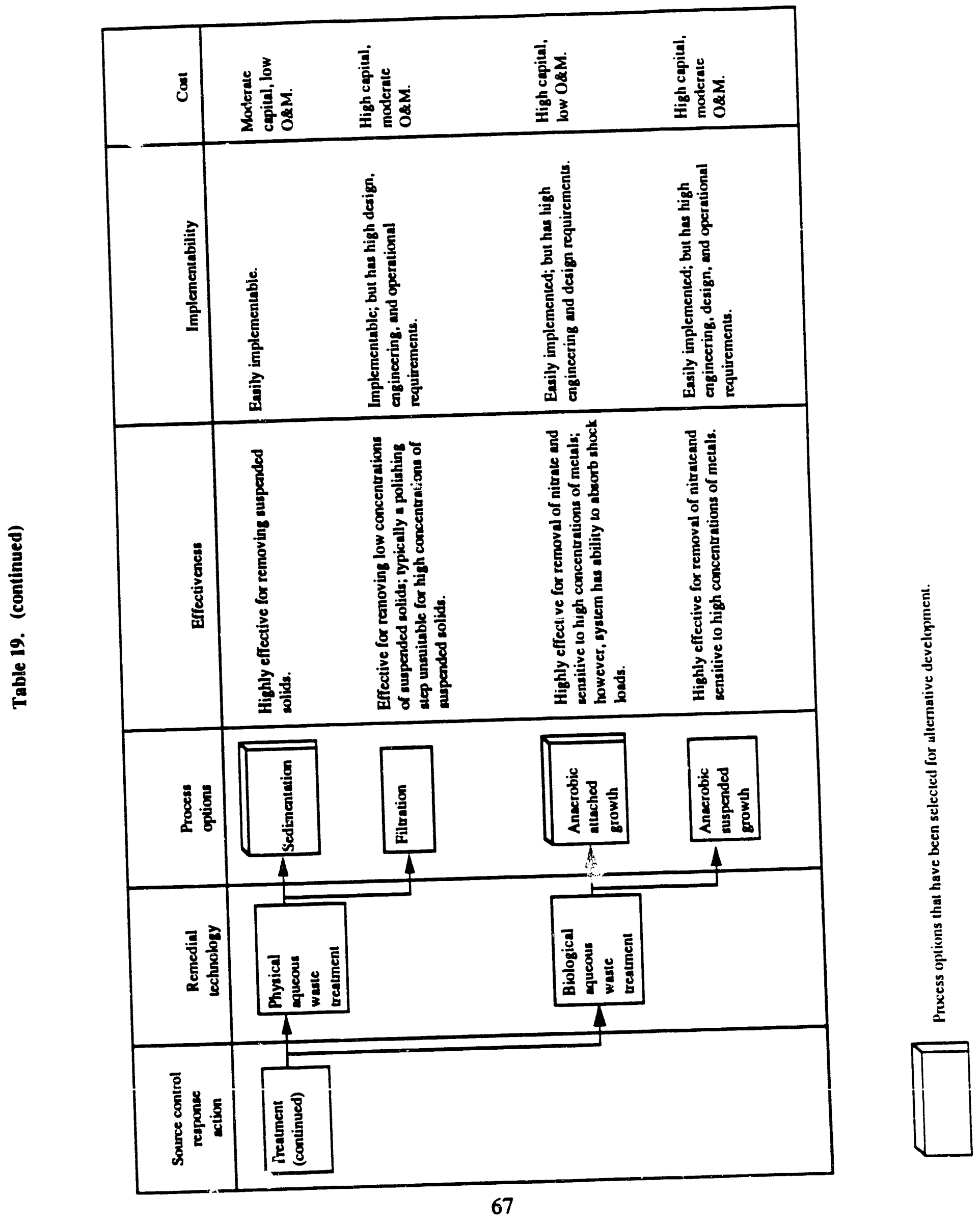





eliminates the chance of direct human contact with contaminated soil/sludge and is technically feasible. This option reduces mobility of contaminants through reduced infiltration but does not reduce contaminant volume or concentration. Multilayer capping processes have relatively moderate to high capital costs and low O\&M costs compared with other cap types.

\subsubsection{Treatment response}

The treatment response requires a combination of technology types to be implemented because of the operations required to remove and treat the contaminants of concern in the drummed sludges. This option reduces the mobility, concentration, and volume of the contaminants. The treatment option has high overall capital costs.

Waste Processing. Waste processing technologies alone do not reduce mobility or concentration of wastes; however, they are an integral part of overall treatment alternatives. The most effective waste processing options are concrete pulverizer, secondary crusher, metal shredder, and a soil washing system. The technologies will effectively reduce the quantity of miscellaneous scrap and process the drummed sludge to leach the contaminants for treatment. The technologies have relatively low to moderate capital and O\&M costs compared with other options in this technology type.

Physical Aqueous Waste Treatment. Sedimentation is the process chosen for the physical aqueous waste treatment. Sedimentation removes the suspended solids in the aqueous waste stream resulting from the leaching of contaminants by waste processing. Sedimentation has moderate capital and low O\&M costs.

Biological Aqueous Waste Treatment. Both anaerobic fixed film and suspended growth biological treatment systems equally degrade nitrate. Attached growth systems are able to absorb influent shock loads, and suspended solids in effluent tend to settle better. Suspended growth systems have slightly higher O\&M costs and requirements. Both systems have high capital costs and design requirements.

Chemical Aqueous Waste Treatment. Neutralization/pH adjustment was selected as the most effective process for chemical wastewater treatment. The EP toxicity test determined that the sludge had a final $\mathrm{pH}$ of 12.3 , indicating that metals in the extract should be in an insoluble state. In addition, suspended solids were assumed to have discrete settling characteristic because of the nature of the source (ground cement). Thus, removal of fine suspended solids and dissolved metals is not believed to be a concern in the wastewater. Precipitation/flocculation can be eliminated. Neutralization/pH adjustment is easily implemented and has low capital and moderate O\&M costs. Treatability studies would be required to develop the specific chemical waste treatment sequence and their design specifications. 


\subsubsection{Disposal actions}

Off-site disposal of the drummed soils/sludges and miscellaneous scrap in a controlled landfill is effective in reducing contaminant mobility, concentration, and volume at the site. The alternative is readily implemented but has a high capital cost.

On-site aqueous treatment by contract treatment companies was selected as most effective. Treatment of aqueous waste at WETF is not easily implemented because of the plant's limited capacity and requirements of their present NPDES permit. Wastewater treatment by contract treatment companies involves low capital costs.

\subsection{DEVELOPMENT OF ALTERNATIVES}

In this section, the optimal process options selected in Sect. 3.1 are combined to form remediation alternatives for drummed soil/sludges and miscellaneous scrap material using the following process:

1. process options are combined in a matrix to form a variety of alternatives that address the drummed soil/sludges and miscellaneous scrap; and

2. alternatives chosen are tailored to reflect variations such as volume of contaminated material and distance to suitable discharge stream. Preliminary cost estimates are then done on the tailored alternatives.

The process options are combined to address site conditions, contaminant combinations, physical characteristics, and site location. A wide range of alternatives is developed, varying from no action to comprehensive mitigation. These alternatives consider various levels of containment, treatment volumes, treatment durations, risks, and disposal options. The site-wide alternatives that result from the development process will be subjected to rigorous individual and comparative analysis in a subsequent section. The development of each alternative follows.

\subsubsection{Alternative 1: No-Action Alternative}

This alternative involves security for the entire site. All drummed soil/sludges and boxes will be left in place. Appropriate warning signs will be placed along the perimeter for additional security. Signs are assumed to be $4 \mathrm{ft}^{2}$, made of steel with reflective coating, and placed at 100-ft intervals. Land use restrictions around the site may be implemented as part of the alternative. Once signs are delivered to the site, completion of the alternative can be accomplished rapidly. Treatment rates and disposal distances are not applicable to this alternative. This alternative has negligible spatial requirements and no imposed limitations. 


\subsubsection{Alternative 2: Containment Via Selective Multilayered Capping}

This alternative involves capping the drummed soils/sludges and miscellaneous scrap (boxes) with a multilayer/multimedia modified RCRA cap for long-term minimization of infiltration.

Minimal site preparation is required to construct the cap. Some movement of barrels and boxes may be necessary to facilitate grading. Additional site preparation with this design includes only minor grading and negligible clearing and grubbing because the land surface at the UNC Disposal Site has only sparse vegetation.

A modified RCRA multimedia cap is composed, at a minimum, of a 24-in-thick clay layer over the drummed soil/sludges and miscellaneous scrap boxes, overlain by a minimum 30-mil synthetic liner, overlain by a polyethylene drainage geonet, overlain by a polypropylene filter fabric, overlain by a minimum 18-in-thick topsoil layer. Some variations of this design may be necessary to accommodate site-specific requirements of the UNC Disposal Site.

The time required for cap construction is relatively shorter than alternatives that use treatment as the principal element. Treatment rates, disposal distances, and imposed limitations are negligible or not applicable to the alternative. Spatial requirements for this alternative include temporary facilities for field offices and both equipment storage and maintenance.

\subsubsection{Alternative 3: Treatment Using a Combination of Solid Waste \\ Processing; Physical, Chemical, and Biological Treatment of the Aqueous Waste; and Modified RCRA Cap}

This alternative treats only the 11,000 drums containing sludges mixed with cement. The 18,000 drums of soil are not treated because they account for only $1 \%$ of the nitrate at the site. Miscellaneous demolition materials are not treated due to compositional variations and negligible nitrate content. The alternative involves four main processing steps: (1) solid waste processing of the drummed sludge, (2) leaching of the nitrate from the sludge, (3) treatment of the nitrate-bearing leachate, and (4) containment of the leached sludge, drummed soil, and miscellaneous boxed scrap.

Solid waste processing involves identifying the drummed sludges from the soils; removing the waste from the barrel; reducing the particle size of the solid waste by primary and secondary crushing; shredding empty barrels; and leaching nitrates from the crushed solid waste.

An excavator with a drum grappling arm would perform the required drum handling from the pile and around the site. Deheading the drum and identifying the contents would 
be performed manually. Drums containing soil would be emptied and their contents isolated until completion of the treatment process.

A concrete pulverizer (primary crushing jaws attached to an excavator) would remove the drum surrounding the concrete and reduce the concrete fragments to a diameter of $<9$ in. The crushed concrete would then be transported to a secondary crusher, where it would be crushed to the optimum particle size for nitrate leaching.

A soil washing system would be used to leach nitrate from the crushed material using aggressive washing and leaching techniques developed in the mineralogical industry. Water, energy, and detention time requirements for the soil washing system would be minimal because nitrate is highly soluble. Treatability studies to determine the final design specifications would be necessary.

Wastewater generated from solid waste leaching would require treatment by neutralization/pH adjustment, anaerobic fixed film treatment, and sedimentation. This treatment scheme represents historic and tested wastewater treatment technology and can be provided by mobile or package systems offered by contract wastewater treatment service firms.

The wastewater treatment in Alternative 3 would be performed by a contract service firm. The aqueous treatment system will include $\mathrm{pH}$ adjustment, a fixed film bioreactor, and sedimentation. Treated effluents would have io meet NPDES discharge criteria and would be directed to a nearby surface stream or the Y-12 Plant storm sewer. Sludges from the treatment process would be placed back in the excavation.

In Alternative 3, the leached crushed sludge, drummed soil, and miscellaneous scrap would be placed back in the existing excavation and covered with a multilayer cap as outlined in Alternative 2. The miscellaneous scrap would be removed from the wooden boxes to prevent void spaces during filling. All barrels would be shredded. Soil would be removed from the drums, placed in the excavation, and the drums shredded.

Limitations include the air emission permit for the crushing of the solid waste and NPDES permit for the liquid discharge. Treatability studies to determine solid waste processing and wastewater characteristics would be required. Spatial requirements for Alternative 3 include temporary facilities for field office, equipment storage, nd maintenance.

The time required for treatment of the : olid waste is relatively long compared with nontreatment alternatives. The main time constraint is issuance of the air perinit. Engineering details of the process may be worked out relatively quickly. 


\subsubsection{Alternative 4: Off-Site Shipment and Disposal}

Shipment and disposal of UNC Disposal Site wastes off Y-12 Plant grounds is considered to provide an alternative involving minimal long-term oversight or maintenance. Potential difficulties exist, however, in obtaining Y-12 Plant and/or DOE approval for shipment of the wastes off-site.

Disposal of UNC wastes off-site involves handling and preparing the waste for shipment, transportation, and disposal at an appropriate facility. Waste preparation is assumed to consist of handling, overpacking drummed soil and sludges, and containing miscellaneous wastes. Transportation would be by truck. Potential low-level radioactive contamination limits the disposal facilities that will accept the wastes. Disposal at an off-site facility may occur only at two locations. Transported wastes may be received by the K-25 Site on DOE ORR, 15 miles west of the Y-12 Plant, and placed in temporary storage pending incineration in the Toxic Substances Control Act incinerator facility upon start-up. Alternately, the wastes may be transported to U.S. Pollution Control's land disposal facility in Beatty, Nevada. Once waste is removed, the site will be backfilled with clean soil and returned to a natural state.

Off-site disposal at the K-25 Site is not the preferred option because of the current backlog of wastes to be treated at the facility and because incineration would not be effective in reducing toxicity, mobility, and volume of the waste. Spatial requirements consist of temporary equipment storage and staging facilities at the UNC Disposal Site as well as long-term land disposal facility spatial requirements resulting from disposal of the wastes. 


\section{DETAILED ANALYSIS OF ALTERNATTVLS}

This section prescnts a detailed analysis of the alternative developed in the preceding chapter. This analysis consists of three phase. First, the aiternatives are further refined with respect to volumes or areas of contaminated media, the technologies and process options to be used, and the performance capabiities and requirements of the technoingies or operations. Second, each alternative is assessed and summaried against nine evaluati in criteria (EPA 1988). These criteria include the following.

1. Short-term effectiveness with respect to protectic of the public, workers, and environment during implementation of the alternatime and estimated time until remedial response objectives are achieved.

2. Long-term effectivess and permanerce, including assessment of residwi risks, adequacy of residual management controls, and reliability of these controls.

3. Performance in reducing mobility, toxicity, and volume of contaminants; amounts of hazardous materials to be treated; and the degree of reductions, as a percentage, in toxicity, mobility, and volume of contaltilnants.

4. Implementability with respect to the technical feasibility of construction and operation; reliability; ease of undertaking additional future actions and monitoring; administrative feasibility; and availability of services and materials.

5. Capital costs and operation and maintenance costs to an accuracy of -30 to $+50 \%$ (if possible), present worth analysis, and sensitivity analysis.

6. Compliance with chemical, action, and location-specific ARARs and any other guidelines pertinent to the site or contaminants.

7. Overall protection of human health and the environment based on the longterm effectiveness and permanence, short-term effectiveness, and compliance with ARARs.

8. State acceptance.

9. Community acceptance.

The third phase consists of a comparative analysis to assess the performance of alternatives relative to each other and with respect to the nine criteria of the second stage. 


\subsection{NO-ACTION ALTERNATTVE}

The no-action alternative involves leaving the drummed soils/sludges and boxes in place, continuing groundwater monitoring, and ensuring site security. The drums, crates, and tarps will be left as is, and no attempt will be made to restack or resituate any drum or crate. The tarp covering the barrels and crates will not be removed or replaced. Groundwater monitoring of the seven wells in the vicinity of the site will be performed. Sampling will be conducted quarterly the first year and semiannually thereafter. Site security will be maintained through posted warning signs around the site and the existing security at the Y-12 Plant, which restricts access to the plant. Warning signs are assumed to be $4 \mathrm{ft}^{2}$, made of reflector-coated steel, and placed at the midpoint of each side of the pit. The noaction alternative does not reduce mobility, toxicity, or volume of contaminants, has a high short-term and low long-term effectiveness, and is readily implemented. There are no NEPA requirements for the no-action alternative. A summary of the nine criteria is presented in Table 20.

\subsubsection{Short-Term Effectiveness}

The implementation of the no-action alternative requires little or no handling of the waste materials. This alternative results in minimum fugitive dust releases, no transport risks, and therefore minimal risk to workers, the public, and the environment.

This alternative can achieve the remedial response target rapidly because the monitoring wells and site security are already in place. In consideration of the time required to order and accept delivery of warning signs, the estimated time of implementation is 3 to 4 months.

\subsubsection{Long-Term Effectiveness and Permanence}

A residual risk is associated with the UNC Disposal Site if left as is. This no-action alternative provides a baseline to judge other alternatives.

To determine the magnitude of potential residual risks under the existing and future conditions at the UNC Disposal Site if the site remains as is (no action), Weston's (1986) modeling results were evaluated. As previously described (Sect. 1.3.1), nitrate and strontium90 were selected as the potential contaminants of concerr.. Thus, groundwater modeling efforts focused on predicting nitrate and strontium- 90 concentrations migrating from the site. Quantification of risk is limited to the adverse health effects of nitrate and strontium-90. 
Table 20. Detailed analysis of Alternative 1: no action

\begin{tabular}{|c|c|}
\hline $\begin{array}{l}\text { Short-term } \\
\text { effectiveness }\end{array}$ & $\begin{array}{l}\text { High degree of short-term effectiveness during implementation due to } \\
\text { low exposure risks to public and workers from fugitive dusts or } \\
\text { disturbance of surface drainage or groundwater flow patterns. }\end{array}$ \\
\hline $\begin{array}{l}\text { Long-term } \\
\text { effectiveness and } \\
\text { permanence }\end{array}$ & $\begin{array}{l}\text { Low long-term effectiveness. Residual risks are equal to those at the } \\
\text { sites at present. Given the objectives of a no-action response, the } \\
\text { monitoring program is adequate and reliable in terms of risk management } \\
\text { control. }\end{array}$ \\
\hline $\begin{array}{l}\text { Reduction of toxicity, } \\
\text { mobility, and volume }\end{array}$ & Does not reduce mobility, toxicity, or volume of contaminants. \\
\hline Implementability & $\begin{array}{l}\text { High technical and administrative feasibility. Material readily available. } \\
\text { High reliability and ease of undertaking future remedial actions. }\end{array}$ \\
\hline \multirow[t]{2}{*}{ Cost } & 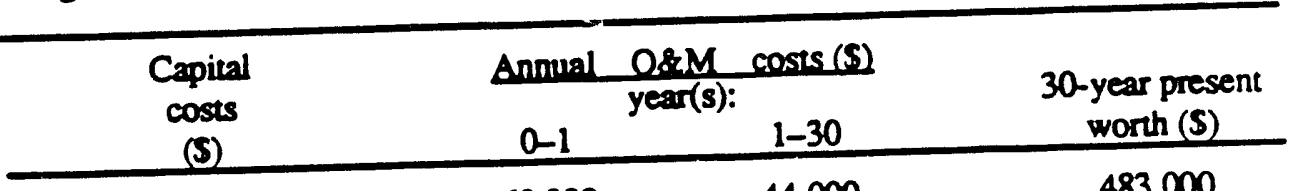 \\
\hline & $\begin{array}{lll}240 & 68,000 & 44,000\end{array}$ \\
\hline $\begin{array}{l}\text { Compliance with } \\
\text { ARARs }\end{array}$ & $\begin{array}{l}\text { No-action alternative is required under NCP; however, it does not } \\
\text { comply with chemical-specific ARARs with respect to the potential } \\
\text { future contaminants in groundwater at the site. Location- and action- } \\
\text { specific ARARs are not applicable to this altemative. }\end{array}$ \\
\hline $\begin{array}{l}\text { Overall protection of } \\
\text { human health and } \\
\text { the environment }\end{array}$ & $\begin{array}{l}\text { Reduces chance of direct exposure to drummed soils/sludges and boxes } \\
\text { but because the material is left in place, reductions in mobility and } \\
\text { toxicity are not incurred. Therefore, a long-term rist to human health } \\
\text { and the environment exists. }\end{array}$ \\
\hline State acceptance & State acceptance of the features of this altemative is not known. \\
\hline $\begin{array}{l}\text { Community } \\
\text { acceptance }\end{array}$ & Community acceptance of the feanures of this altemative is not known. \\
\hline
\end{tabular}


As discussed in Sect. 1.2.5, the pathways analysis indicates no current or likely future human exposure to contaminants at the UNC Disposal Site. Nevertheless, as a conservative means of evaluating the effectiveness of the postclosure alternatives, human exposure was assumed to occur through ingestion of nitrate or strontium- 90 contaminated groundwater.

To evaluate the noncarcinogenic effects of nitrate, a measure of the potential health risk is obtained by comparing exposure levels to the RfD. Potential nitrate exposure levels, calculated for ingestion of groundwater, are identified as milligrams per kilogram of body weight per day (mg/kg-day). Equation 1 and the variables listed in Table 21 , used to calculate nitrate exposure levels, are taken from the Risk Assessment Guidance for Superfund (EPA 1989b). For the no-action alternative, Wesionils (1986) modeling predicted 10 years for the nitrates to reach the groundwater system from a source inventory of $58 \mathrm{t}$ (Weston 1986). After $\sim 13$ years, steady-state conditions exist. The maximum nitrate concentration predicted by the WMPLUME model for the defined conditions was $193 \mathrm{mg} / \mathrm{L}$. This concentration was predicted at only one location close to a source point. The exposure level (E) for $193 \mathrm{mg} / \mathrm{L}$ as listed in Table 22 is $5.51 \mathrm{mg} / \mathrm{kg}$-day along with the verified RfD for nitrate of $1.6 \mathrm{mg} / \mathrm{kg}$-day. The hazard quotient $(\mathrm{E} / \mathrm{RfD})$ is then calculated to determine the potential for noncarcinogenic effects of nitrate. The hazard quotient (HQ) for the groundwater nitrate concentration of $193 \mathrm{mg} / \mathrm{L}$ is 3.4 . This HQ exceeds unity (1), indicating that the no-action alternative may result in nitrate concentrations that may cause adverse noncarcinogenic health effects. As previously stated, human exposure is not occurring and was only assumed as a means of evaluating the effectiveness of the treatment alternatives.

Potential strontium-90 exposure levels are identified as picocuries and are calculated using Equation 2 along with the variables listed in Table 21. To evaluate the carcinogenic effects of strontium-90, a measure of the potential health risk is obtained by comparing exposure levels to the strontium-90 ingestion slope factor. For the no-action alternative, Weston's modeling assumed 10 years for strontium- 90 to reach the groundwater system from a source inventory of $26 \mathrm{mCi}$. The maximum concentration predicted by the WMPLUME model for the defined conditions was $50 \mathrm{pCi} / \mathrm{L}$. The exposure level (E) for $50 \mathrm{pCi} / \mathrm{L}$ is 2.5 $\mathrm{E}+6 \mathrm{pCi}$ as listed in Table 23 along with the slope factor (SF) for ingestion of $3.3 \mathrm{E}-11$. Risk is then calculated $(E \times S F)$ to determine the probability of an individual developing cancer over a lifetime as a result of exposure to the potential carcinogen. Based on conditions modeled at the UNC Disposal Site in 1985, the predicted risk for the no-action alternative is 8.3 E-5, which is within EPA's range of concern (1.0 E-4 to 1.0 E-6).

A no-action alternative has an overall low long-term effectiveness because the postimplementation residual risks are equal to those now at the site. In consideration of the short-term objectives of the no-action response, the presence of warning signs and restricted access should minimize the risk of direct human contact with contaminated media and are therefore adequate and reliable. The continuation of the monitoring program at existing wells should suffice to evaluate contaminant migration. 
Table 21. Equations and variables for the groundwater ingestion scenario ${ }^{\circ}$

Eq. 1. Nitrate exposure level $(\mathrm{mg} / \mathrm{kg}$-day $)=\mathrm{CW} \times \mathrm{IR} \times \mathrm{EF} \times \mathrm{ED}$

Eq. 2. $\quad$ Sr-90 exposure level $(p C i)=C W \times I R \times E F \times E D$

Where:

$\mathrm{CW}=$ Chemical concentration in water (milligram/liter or picocurie/liter)

IR = Ingestion rate (liter/day)

$E F=$ Exposure frequency (days/year)

$E D=$ Exposure duration (years)

BW $=$ Body weight (kilogram)

$\mathrm{AT}=$ Averaging time (period over which exposure is averaged)

Values:

$\mathrm{CW}=$ Weston's modeled groundwater concentrations

$\mathrm{IR}=2 \mathrm{~L} /$ day $^{\circ}$

$E F=365$ days/year

$\mathrm{ED}=70$ years $^{a}$

$\mathrm{BW}=70 \mathrm{~kg}$

$\mathrm{AT}=365$ days $\times \mathrm{ED}^{a}$

- Source: Risk Assessment Guidance for Superfund (EPA 1989). 
Table 22. Evaluation of treatment alternatives for nitrate based on a groundwater ingestion scenario.

\begin{tabular}{lcccc}
\hline Alternative & $\begin{array}{c}\text { Nitrate concentration } \\
(\mathrm{mg} / \mathrm{L})\end{array}$ & $\begin{array}{c}\text { Exposure } \\
\text { level }\end{array}$ & $\begin{array}{c}\text { RfDc } \\
\text { (mg/kg-day) }\end{array}$ & $\begin{array}{c}\text { Hazard quotient } \\
\text { (E/RfD) }\end{array}$ \\
\hline $\begin{array}{l}\text { No action } \\
\begin{array}{l}\text { Treatment option } \\
\text { w/modified RCRA } \\
\text { cap }\end{array}\end{array}$ & $193^{a}$ & 5.51 & $1.6^{d}$ & 3.44 \\
$\begin{array}{l}\text { Modified RCRA } \\
\text { cap }\end{array}$ & 2 & 0.06 & $1.6^{d}$ & 0.04 \\
\hline
\end{tabular}

aSource: Weston (1986)

balculated using Eq. 1 and the variables in Table 21.

cReference Dose

¿Source: EPA's RfD Work Group Meeting Notes (August 22, 1990) 
Table 23. Evaluation of treatment alternatives for strontium-90 based on a groundwater ingestion scenario.

\begin{tabular}{lcccc}
\hline Alternative & $\begin{array}{c}\text { Sr-90 Concentration } \\
(\mathrm{pCi} / \mathrm{L})\end{array}$ & $\begin{array}{c}\text { Exposure } \\
\text { level } \\
(\mathrm{pCi})\end{array}$ & $\begin{array}{c}\text { SFc } \\
(\mathrm{pCi})^{-1}\end{array}$ & $\begin{array}{c}\text { Risk } \\
\text { (E x SF) }\end{array}$ \\
\hline $\begin{array}{l}\text { No action } \\
\begin{array}{l}\text { Treatment option } \\
\text { w/modified RCRA } \\
\text { cap }\end{array}\end{array}$ & 50 & $2.5 \mathrm{E}+6$ & $3.3 \mathrm{E}-11^{d}$ & $8.3 \mathrm{E}-5$ \\
$\begin{array}{l}\text { Modified RCRA } \\
\text { cap }\end{array}$ & $\mathrm{NA}^{e}$ & $\mathrm{NA}$ & $3.3 \mathrm{E}-11^{d}$ & $\mathrm{NA}$ \\
\hline
\end{tabular}

aSource: Weston's addendum (1990)

bCalculated using Eq. 2 and the variables in Table 21.

cSlope factor

dSource: Health Effects Assessment Summary Tables, 4th Quarter FY-1190 (September 1990)

Not available 


\subsubsection{Reduction of Toxicity, Mobility, and Volume}

The no-action alternative does not treat the source material for contaminant reduction and therefore does not reduce the toxicity or volume of the source material. Negligible mobility reduction is attained through the polyvinyl chloride (PVC) tarps covering some of the contamination and the low-permeability clay underlying the site. The toxicity, mobility, and volume of contaminants present under no-action are discussed in Sect. 4.1.2.

\subsubsection{Implementability}

The design, engineering, and administrative requirements associated with a no-action option are essentially negligible. Materials required for the components of this alternative are readily available. The remedial action objectives are achieved with the continuation of groundwater monitoring and the installation of the warning signs.

\subsubsection{Cost Analysis}

The direct capital cost for the no-action alternative includes the preparation of reflective warning signs. Indirect capital costs includes a $31 \%$ contingency cost and a $25 \%$ charge for engineering and design support (Energy Systems 1990b). The total capital cost for this option is $\$ 240$. The capital costs and cost basis are presented in Appendix A, Tables A.1 and A.2, respectively.

The O\&M costs for this option include groundwater monitoring, site monitoring and maintenance, and drainage maintenance and erosion control. Groundwater sampling of the seven wells is estimated to cost $-\$ 12,000$ per sampling round, with yearly maintenance of the site to cost $\sim \$ 20,000$. Other $O \& M$ costs include project management, insurance, and contingency costs; these are estimated to be $30 \%$ of the total capital cost. Details of the O\&M cost are presented in Appendix A, Table A.3.

A detailed analysis was performed to determinie the present worth of this alternative over a 30-year life. The present worth was compiled to be $\$ 483,000$ (Appendix $A$, Table A.4). A sensitivity analysis was performed for this alternative based on a change in the sampling frequency to annually and quarterly. Tables A.5 and A.6 present the possible changes in the O\&M costs and their effects on the present worth analysis.

\subsubsection{Compliance with ARARs}

There is no evidence of contaminated groundwater or soil at the UNC Disposal Site, so no chemical-specific ARARs for cleanup are applicable. However, groundwater modeling predicted potential contamination of groundwater to levels exceeding SDWA MCLs if the present site conditions (uncapped, exposed excavation) were left as is (no action). Because the no-action alternative will not comply with MCL for nitrate and strontium-90, chemical- 
specific ARARs are not met. Location- and chemical-specific ARARs are not applicable to the alternative since no action is taken.

\subsubsection{Overall Protection of Human Health and the Environment}

The no-action alternative has a low degree of overall protection of human health and the environment because of its low degree of long-term effectiveness and permanence and its future potential to impact chemical-specific ARARs.

\subsubsection{State Acceptance}

No specific comments regarding the components of this alternative are now available.

\subsubsection{Community Acceptance} available.

No specific public comments concerning the components of this alternative are

\subsection{MODIFIED RCRA CAP ALTERNATIVE}

This alternative consists of closing the UNC Disposal Site by in-place capping. Capping is a demonstrated technology for landfill closure that provides for the mitigation of source material releases from soils above the saturation zone.

The design and performance objectives of the cap are to minimize liquid infiltration into the disposal area, promote proper drainage, minimize erosion, accommodate settling and subsidence, and ensure isolation of the drums and boxes. Caps have historically been constructed of several materials, such as clay, bentonite clay, cement-stabilized sand, synthetic membranes, asphalt, and concrete (Cadwallader 1986). The modified RCRA cap (Fig. 8) will be constructed using both a synthetic membrane and low-permeability soil (clay), thus increasing the factor of safety associated with the design life of the cap.

Before the ORR NPL listing, the capping alternative was submitted for NEPA review. A categorical exclusion for this alternative was approved by the Director of Environmental Restoration and Waste Management (EM-1) on June 15, 1990, and concurred by the Director of Office of NEPA Project Assistance (EH-25) on July 2, 1990. No further NEPA review is required for this alternative. 


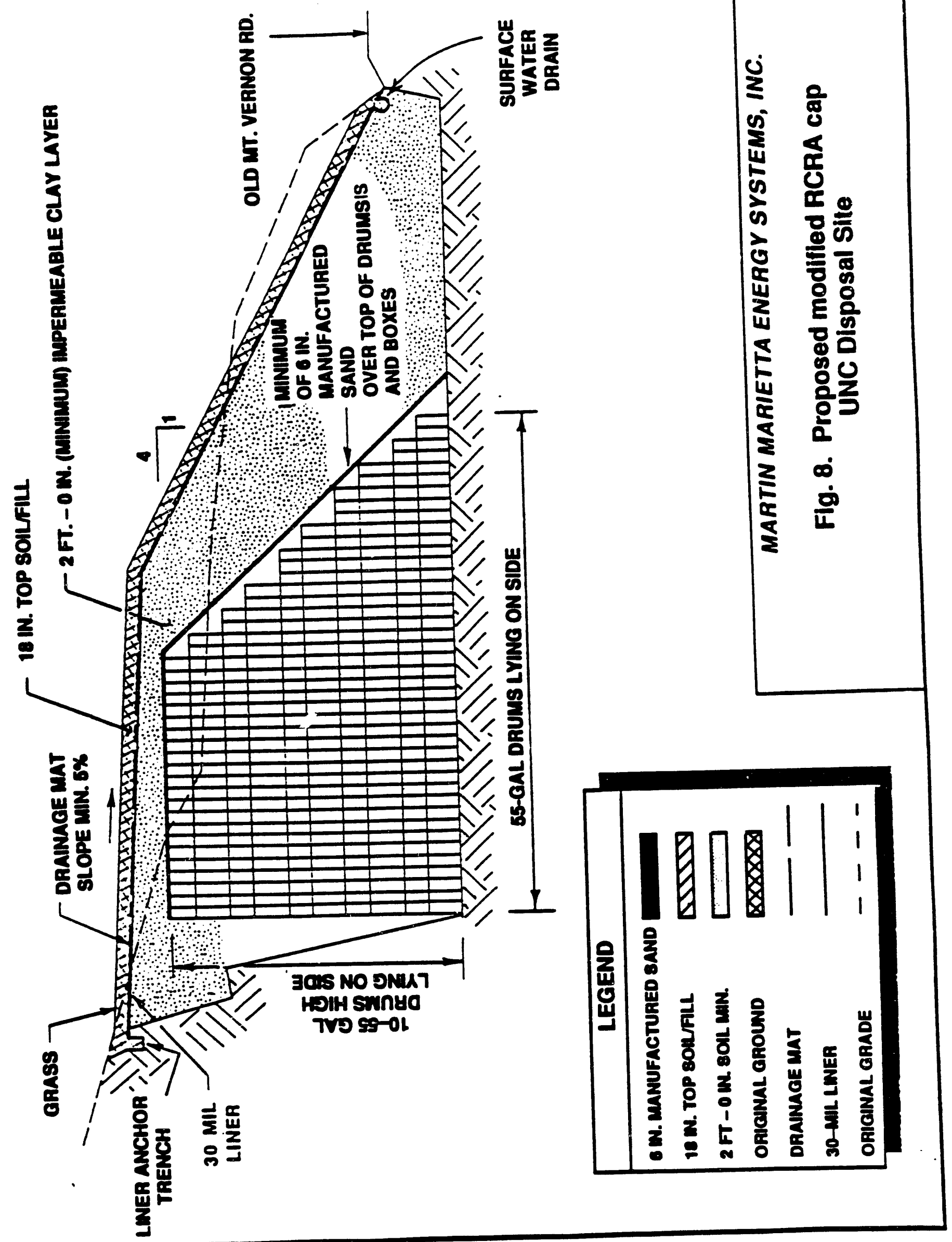




\subsubsection{Description of the Modified RCRA Cap}

\subsubsection{Low-permeability soil cap}

Low-permeability soil may consist of clay, bentonite clay, or cement-stabilized sand. Clay has advantages and disadvantages as the primary barrier against infiltrating water. One advantage of clay over the cement-stabilized sand and the synthetic membrane is its selfhealing ability. If a portion of a clay layer dries and cracks, application of water will cause the clay to swell and will often restore it to an impermeable state. In the past, clay has proven to be the most practical and the most popular material for landfill caps and liners. However, recent studies have revealed a number of factors that can contribute to increasing the permeability of the clay.

Solutions of hydrocarbons and acidic or basic solutions can seriously increase the permeability of clays. The permeability of a clay is highly sensitive to the water content and degree of compaction. The field permeability of the compacted clay usually greatly exceeds the measured laboratory permeability due to the presence of cracks, fissures, and interclod voids, which are inherent in the larger scale of the field. Clay caps are also susceptible to differential settling and desiccation. Both of these processes cause cracks that lead to increased permeability (Cadwallader 1986).

Cement-stabilized sand is also susceptible to cracking, particularly in the presence of acidic solutions. Unlike clay, cement-stabilized sand has no self-healing properties (Cadwallader 1986).

The low permeability of a soil or clay layer forms a barrier to reduce the infiltration of water. The clay layer is required to have a minimum compacted thickness of $24 \mathrm{in}$., be compacted to at least $90 \%$ of its dry density at its optimum water content, and be constructed of a material with low hydraulic conductivity (i.e., $1 \times 10^{-7} \mathrm{~cm} / \mathrm{s}$ ).

A low-permeability soil cap design would typically consist of a top layer of loam (also known as the vegetative layer) above a drainage layer of clean sand and/or a synthetic drainage mat. The drainage layer provides for lateral drainage of infiltrating water, thus preventing pooling on the barrier layer. The clay layer typically rests on a layer of fine sand placed over the graded backfill or drummed material.

The loam layer at the surface supports vegetation, reduces erosion, and offers protection to the clay layer. The loam layer is required to be sufficiently thick and composed of soils that will support the selected vegetation for the life of the cap. In addition, the vegetative layer will not have root systems that could compromise the drainage layer or the impermeable cap. 
The sand layer below the low-permeability soil forms a supplemental capillary barrier that helps to prevent the soil particles from downward migration and provides adequate structural support for the final cover. The fine sand layer must be free of any material that could damage or abrade the impermeable layer and be graded such that the final top slope of the cap will be at least $5 \%$, and the side slopes will be a maximum ratio of four horizontal to one vertical $(4: 1)$.

In addition, a synthetic filter medium is often placed between the drainage layer and the vegetative layer or between the clay layer and the capillary barrier. The synthetic filter medium provides a redundancy in the design to prevent the infiltration of water into the waste disposal area.

\subsubsection{Synthetic membranes}

Synthetic membranes have become appealing as impermeable caps and liners because of their negligible permeability and their chemically resistant properties. The materials commonly used as synthetic membranes include

1. butyl rubber,

2. chlorinated polyethylene (CPE),

3. chlorosulfonated polyethylene (CSPE - hypalon),

4. epiclorohydrin rubber (ECO),

5. ethylene propylene rubber (EPDM),

6. ethylene propylene terpolymer (EPT),

7. low density polyethylene (LDPE),

8. high density polyethylene (HDPE),

9. neoprene (chloroprene rubber),

10. polyvinyl chloride (PVC), and

11. thermoplastic elastomers.

Only three of the above polymers have achieved widespread use. Initially, butyl rubber was the synthetic membrane of choice, followed by hypalon (CSPE). Recently, however, the high density polyethylene (HDPE) membranes have virtually replaced butyl rubber and hypalon as the industry preference (Cadwallader 1986). 
A vulcanized butyl rubber compound is used in the manufacture of the synthetic membranes and is available in either unsupported or fabric-reinforced versions of 20- to 125mil thickness. Butyl rubber has excellent resistance to water permeation and swelling. This compound has poor resistance to hydrocarbons but is quite resistant to animal and vegetable oils and fats. Some butyl compounds break down (crack) after prolonged exposure to ozone. Obtaining good splices of butyl rubber in the field may be a problem because cold curing adhesives are required (Geswein 1975).

Hypalon can be used in both vulcanized and unvulcanized compounds and is available in sheets of 30- to 45-mil thickness. This compound is puncture resistant; easy to seam with solvents, cements, or heat; and has excellent resistance to weathering, aging, oil, and bacteria (U.S. EPA 1977). The main disadvantages of hypalon are the high cost and low tensile strength.

At one time, PVC membranes were also widely used as flexible liners. These membranes are available in wide sheets of 10- to 30-mil thickness. PVC compounds contain 30 to $50 \%$ of one or more plasticizers to make the films flexible and rubber-like. PVC polymers generally hold up well in burial tests; however, plasticized compounds of PVC films have deteriorated rapidly, presumably due to the biodegradability of the plasticizer. Some plasticizers are also soluble to a limited extent in water (U.S. EPA 1977). On exposure to weather, PVC liner materials can deteriorate rapidly due to loss of plasticizer and to polymer degradation. Plasticized PVC films are quite resistant to punctures and relatively easy to splice by solvent welding, adhesive, and heat. PVC may become stiff at low temperatures, thus making cold-weather installation a problem.

HDPE has high strength, toughness, durability, chemical resistance, and stress crack resistance. Very effective seaming techniques are also available for HDPE. The main drawback to the HDPE synthetic membrane would be improper seaming or a lack of proper quality control during the seaming of the polyethylene sheets. When properly performed, welding techniques can result in a strong homogeneous seam that is as chemically resistent as the membrane itself (Cadwallader 1986).

\subsubsection{Site-specific preparation and construction}

Before constructing the modified RCRA cap at the UNC Disposal Site, the following activities will be conducted to prepare the area for closure: removing the existing PVC sheeting from the 55-gal drums; placing the boxes of waste next to the drums; and placing erosion-control devices at the limits of the work area.

Vibratory methods (i.e., by a combination of hand plate compaction and steel drum roller) may be used to fill the voids between the drums with limestone sand and/or flyash. Other methods under consideration for filling the void spaces include air blowing the limestone sand into the voids with sand blasting equipment; pouring wet concrete over the drums and vibrating the mixture in; and using high-pressure grouting techniques to pump 
a slurry solution (cement, lime, and flyash) into the voids. In addition, a minimum of 6 in. of limestone sand/flyash will be placed in a layer on top of the drums. The limestone sand will provide a source of carbon dioxide to act as a buffer for the ettringite (a nitrate- or sulfate-based expansive agent) that may leach from the wastes fixed in concrete, thus lowering the acidity of the leachate.

A minimum 24-in.-thick compacted soil layer (note Fig. 8) will be placed over the limestone sand and drum surfaces. Local clays (with an average field permeability of $9.5 \times 10^{-5} \mathrm{~cm} / \mathrm{s}$ ) removed during the excavation of the disposal site will be used for construction of this layer. The soil will be placed in 6-in. lifts and will be compacted and contoured to maximize runoff and minimize infiltration. The final top slope of the cap will be at least $5 \%$, and the side slopes will be no steeper than a maximum ratio of four horizontal to one vertical (4:1).

A suitable synthetic sheeting (30-mil thick) will be placed over the clay. This synthetic membrane will provide an additional low permeability boundary to prevent water from infiltrating and has the ability to deform during settlement without rupturing.

A polyethylene drainage geonet placed over the 30 -mil membrane will provide lateral drainage from the synthetic membrane and prevent flooding or pooling from surface water runon or runoff. A polypropylene filter fabric will be placed over the drainage layer to protect it from the downward migration of soil fines from the vegetative cover and to prevent burrowing animals from puncturing the synthetic liner. An 18-in.-thick vegetative cover will be installed using local, loosely packed soils to support the grass cover.

The following sections present an assessment of the modified RCRA cap, incorporating nine evaluation criteria. The nine criteria aid in evaluating the alternative for long- and short-term effectiveness; reduction of toxicity, mobility, and volume; protection of human health and the environment; compliance with ARARs; implementability and cost; and state and community acceptance (U.S. EPA 1988). A summary of the nine criteria is presented in Table 24.

\subsubsection{Short-Term Effectiveness}

The UNC Disposal Site is fenced, and public access is restricted. Because the source material is contained in boxes and 55-gal drums and the cap is to be constructed at the approximate existing grade with minor disturbance of the drums, risks to public health caused by construction of the cap are unlikely. Similarly, hazards associated with exposure to the contaminants of the workers constructing the cap are minimal. During construction of the cap, workers on-site will follow the safety measures included in the site-specific health and safety plan. In general, little threat exists to human health during the construction of the firial closure cap. 
Table 24. Detailed analysis of Alternative 2: modified RCRA cap

\begin{tabular}{|c|c|}
\hline $\begin{array}{l}\text { Short-term } \\
\text { effectiveness }\end{array}$ & $\begin{array}{l}\text { Risks to public health during construction unlikely. Minimal exposure to } \\
\text { workers from fugitive dust. Expected time frame for completion of the } \\
\text { cap is } 8 \text { months, including } 3 \text { months for construction activities. }\end{array}$ \\
\hline $\begin{array}{l}\text { Long-term } \\
\text { effectiveness and } \\
\text { permanence }\end{array}$ & $\begin{array}{l}\text { High degree of long-term effectiveness if proper construction techniques } \\
\text { and an effective maintenance and inspection program are followed. } \\
\text { Potential nitrate and strontium-90 contamination in groundwater is } \\
\text { remediated below the MCL. }\end{array}$ \\
\hline $\begin{array}{l}\text { Reduction of toxicity, } \\
\text { mobility, and volume }\end{array}$ & $\begin{array}{l}\text { Reduces mobility of contaminants by encapsulating and isolating the } \\
\text { source from the underlying aquifer system. This alternative minimizes } \\
\text { further leachate production and potential future contamination of } \\
\text { groundwater. }\end{array}$ \\
\hline Implementability & $\begin{array}{l}\text { Technically and administratively feasible. Site preparation and final } \\
\text { selection of capping materials requires considerable planning and } \\
\text { engineering. Design must plan for minimizing all potential voids within } \\
\text { the waste pile to prevent subsidence of the cap. }\end{array}$ \\
\hline \multirow[t]{2}{*}{ Cost } & 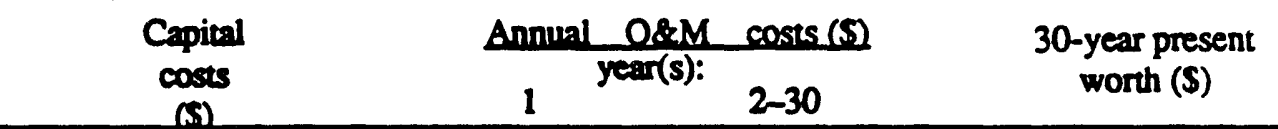 \\
\hline & $\begin{array}{lll}780,500 & 93,600 & 69,800\end{array}$ \\
\hline $\begin{array}{l}\text { Compliance with } \\
\text { ARARs }\end{array}$ & $\begin{array}{l}\text { Action- and location-specific ARARs are met at implementation of } \\
\text { alternative. Chemical-specific ARARs for the potential groundwater } \\
\text { contamination are met. }\end{array}$ \\
\hline $\begin{array}{l}\text { Overall protection of } \\
\text { human health and } \\
\text { the environment }\end{array}$ & High degree of protection of human health and environment. \\
\hline State acceptance & $\begin{array}{l}\text { Specific state comments of the features of this alternative are not } \\
\text { available at present. }\end{array}$ \\
\hline $\begin{array}{l}\text { Community } \\
\text { acceptance }\end{array}$ & $\begin{array}{l}\text { Specific community comments of the features of this alternative are not } \\
\text { available at present. }\end{array}$ \\
\hline
\end{tabular}


The primary environmental impacts resulting from the implementation of this alternative are dust emissions. Dust emissions will arise from the transportation and grading of clean backfill and cover materials and should not be considered a risk to human health. Dust emissions may be controlled by using a water truck to spray the soils to keep them moist or by applying calcium chloride or dust suppressant foams.

The remedial response objectives are achieved almost immediately on completion of the cap. The expected time for completion of the cap alternative is -8 months, which includes 3 months for cap construction. After completion of the modified RCRA cap, the infiltration of water will be negligible, leaving the moisture remaining in the soil to percolate through the drums and boxes. The remedial response objective is met when there is no longer any percolating water to transport the contaminants from the source materials to the groundwater.

\subsubsection{Long-Term Effectiveness and Permanence}

To determine the potential for contaminant migration after capping the UNC Disposal Site, the fraction of precipitation that could potentially infiltrate the cap and drummed soils/sludges was modeled to predict the nitrate and strontium-90 concentration in the groundwater. The modeling of infiltration surface water through the modified RCRA cap resulted in a groundwater nitrate and strontium-90 concentration of $8 \mathrm{mg} / \mathrm{L}$ (Weston 1987) and $2 \mathrm{pCi} / \mathrm{L}$ (Weston 1990), respectively. The hazard quotient associated with the nitrate concentration of $8 \mathrm{ing} / \mathrm{L}$, assuming people were to drink the groundwater in this area, is 0.14 . A hazard quotient $<1$ is acceptable and indicates no adverse health effects are likely to occur from ingestion of nitrate contaminated groundwater. This is a reasonable assumption considering the MCL for nitrate is $10 \mathrm{mg} / \mathrm{L}$ (EPA 1990). The risk level associated with the modeled strontium- 90 concentration of $2 \mathrm{pCi} / \mathrm{L}$ is $3.3 \mathrm{E}-6$, which is within EPA's range of concern. However, it is lower than the risk associated with the no-action alternative. The risk numbers provided are to be used for a relative comparison between alternatives and should not imply that exposure is occurring or will ever occur.

The long-term effectiveness of the modified RCRA cap is directly related to the quality assurance/quality control (QA/QC) procedures conducted during the construction of the cap. A deficiency in the construction of the cap or failure in the cap integrity would result in water infiltration, allowing transport of contaminants from the source material to underlying soils, and, ultimately, to the groundwater.

The modified RCRA cap will likely meet or exceed its long-term performance specifications if constructed properly and if the QA/QC standards are followed. Synthetic membranes have not been in use long enough to have an observable design life. However, accelerated aging techniques indicate that PVC is durable and long lasting when properly constructed and seamed (Cadwallader 1987). The low-permeability soil caps are susceptible to hydrocarbon solutions, acidic or basic solutions, and freezing. The properties of the clay 
cap that determine its design life include the degree of compaction and water content. The built-in redundancy of the multimedia cap reduces the probability of cap failure.

Long-term management, operation, and maintenance is important to maintaining the integrity of the cap. Periodic inspections at regular intervals will be performed by a qualified individual or firm. The site inspections will include documentation of precipitates on the ground, odors, intermittent seeps, soft spots, erosional defects, depressions and puddles, subsidence, and vegetative stress. Some potential long-term problems may include erosion, an inadequate drainage system, slope failure, subsidence, differential settlement, flooding, vegetation failure, frost disturbance, cracking, plugging of porous soil, and deterioration of synthetics. Routine inspections will identify these and other problems, and immediate repairs will be possible. The vegetative cover will be maintained and groomed periodically, and soil reconditioning will be done as necessary to perpetuate the vegetation (Lutton 1987).

Replacement of the cap or components of the cap will eventually be necessary. Should the cap need replacement or repair, an increased risk may be associated with the infiltration of water through the drums and boxes to the groundwater. If the cover is constructed properly, there is a high degree of confidence that the periodic inspections will reveal any potential problems in time for repairs to be made before substantial infiltration can occur. One uncertainty associated with the land disposal of the untreated source material is that a failure in the cap could result in contamination of the groundwater.

In general, the long-term effectiveness of the cap depends on maintaining proper QAVQC standards during construction. Also, an effective maintenance and inspection program will ensure that any potential problems are corrected expeditiously.

\subsubsection{Reduction of Toxicity, Mobility, and Volume}

This alternative does not provide for treatment of the source material; therefore, neither a reduction of the toxicity of the source material nor a reduction in volume of the source material will result. Implementation of this option would minimize leachate production and potential future contamination of groundwater by lowering the water table under the site and by preventing rainwater from percolating through the drums and boxes. Since elevated concentrations of metals, inorganic constituents (including nitrates), and radionuclides were not detected in the groundwater, capping should continue to isolate the source from the underlying aquifer system.

\subsubsection{Implementability}

Complications that may cause difficulties or delays in construction of the final closure cap include wet and/or cold weather. Cold weather could cause variable freezing in either the backfill material or the cap construction material, which may result in subsidence or differential settling. Wet weather could cause delays in construction due to difficulties in 
grading and compacting the backfill material. Severe erosion can often result from heavy precipitation during cover construction.

The technology for installing a modified RCRA cap is well known and is not likely to cause delays. However, uncertainties related to construction, which would be determined during the QA/QC procedures, could result in schedule delays. QA/QC procedures may reveal materials not meeting specifications and improper construction techniques. Furthermore, spot sampling and testing may result in an unacceptable assessment (i.e., compaction or seam failures).

Capping is a generally available technology and has been sufficiently demonstrated for final closures of landfills. Similar caps have been extensively used at the Y-12 Plant. No further technical development is required for capping; therefore, this technology is available for full-scale use if determined the preferred alternative. Adequate specialists and equipment are readily available for construction of the cap. Competitive bidding is possible due to the large number of vendors and specialists available for implementing this technology.

\subsubsection{Cost Analysis}

The direct capital costs for this alternative incorporate costs for site preparation and construction of the cap (including labor, equipment, and QAVQC testing). Indirect capital costs include engineering and design and a $31 \%$ contingency cost. The total capital cost for installation of the previously described modified RCRA cap is \$780,500 (Appendix A, Table A.7).

The O\&M costs for the modified RCRA cap include groundwater monitoring, site inspections, mowing and revegetation, erosion control, drainage maintenance, repairs to the cap materials, and grooming equipment. Other O\&M costs include project management, insurance, and contingency costs. The estimated yearly maintenance cost for the cap is $\$ 69,300$ (Appendix A, Table A.9). The present worth O\&M costs are based on a 10\% discouni rate and a 30-year design life. The total present worth O\&M costs for the cap are $\$ 687,000$ (Appendix A, Table A.10).

The following factors were considered in the sensitivity analysis of this alternative:

1. effective life of the remedial action,

2. duration of cleanup,

3. volume of contaminated material,

4. operation and maintenance costs, and 


\section{5. discount rates.}

The effective design life of the modified RCRA cap is 30 years provided that proper installation and maintenance procedures are followed. As part of the O\&M costs, an allowance (3.3\% 'f the modified RCRA cap costs) was prorated over the 30-year design life to provide for the full replacement of all components of the cap. Therefore, the future costs to prepare and replace the cap components will not be significantly affected by failure of the cap.

The total capital costs for the construction of a modified RCRA cap are relatively insensitive to potential uncertainties that could develop over the brief period of time ( $\sim 3$ months) required for the implementation of the closure plan and remediation of the site. Total capital costs are based on 1990 dollars and are derived from actual quantities and unit prices. The total capital costs for the site remediation will be committed during the 3-month construction period and are not dependent on future O\&M costs.

The volume of the encapsulated waste will remain constant over the 30-year design life of the cap. Capital will not be expended in the future to dispose of additional contaminated materials.

Allowances have been estimated for site inspections, groundwater monitoring, mowing and vegetation, erosion control, and cap maintenance and replacement. The cosi estimates were made assuming a reasonable amount of activity that should take place to properly operate and maintain the cap. Allowances for project management, insurance, and contingencies were estimated at $1 \%$ of the total capital cost. Using a discount rate of $10 \%$, the present worth O\&M costs are $\$ 687,000$. The cost estimate presented above is a fairly accurate representation of the future cost over the 30-year design life of the modified RCRA cap.

\subsubsection{Compliance with ARARs}

Action- and location-specific ARARs are met at the time $o_{i}^{-i}$ implementing this alternative. The general requirements for the capping action are set forth in 40 CFR 264.228 (surface impoundments), 40 CFR 264.258 (waste piles), and 40 CFR 254.310 (landfills). Although none of these is applicable to the UNC Disposal Site, each may be considered relevant and appropriate to remedial alternatives considered at the site. Only the requirements for landfills are listed here. Design and construction requirements specific to landfills are found at 40 CFR 264.300 et seq and TCA 1200-1-11-.14 and are listed in Table 14. These federal and Tennessee requirements state that the cover must be designed and constructed to provide long-term minimization of migration of liquids through the capped area, function with minimum maintenance, promote drainage and minimize erosion or abrasion of the cover, and accommodate settling and subsidence so that the cover's integrity is maintained. Additionally, to keep water and leachate from collecting in the 
waste, the cap should have a permeability less than or equal to the permeability of any bottom liner system or natural subsoils present.

General closure and postclosure care regulations appear at 40 CFR 264.110 (Table 14). Postclosure care must begin after closure and continue for $\mathbf{3 0}$ years after that date. Long-term maintenance must be provided for the runon diversion system, cover system, cap, groundwater monitoring system, and leachate collection and treatment systems.

There is no evidence of contaminated groundwater or soil at the UNC Disposal Site, so no chemical-specific ARARs for cleanup are applicable. However, groundwater modeling predicted potential contamination of groundwater to levels exceeding MCLs. Alternative 3 will reduce the potential leaching of nitrate and strontium-90 to below MCLs, thus ensuring compliaince with cheminal specific ARARs.

\subsubsection{Overall Protection of Human Health and the Environment}

The modified RCRA cap offers a high degree of protection to human health and the environment. The construction of the clost sap will secure the source material from direct human contact; thus, potential impacts $t$ human health from the source area will be $\because$ minated. Capping the source area eliminate: risks to public health and safety and the environment that are associated with excavating, transporting, storing, and handling the source material. In addition, the cap, when installed correctly, will protect the environment from the continuous release of contaminants from the drums and boxes. The cap will minimize infiltrating water, thus minimizing the "ransport of contaminants to the groundwater.

\subsubsection{State Acceptance}

Specific state comments on the freatures of this alternative are not yet available.

\subsubsection{Community Acceptance}

Specific community comments on the features of this alternative are not yet available.

\subsection{TREATMENT AND CAPPING ALTERNATTVE}

At the UNC Disposal Site, $99 \%$ of the nitrate is associated with the drummed sludges. Treatment of the drummed sludges essentially eliminates the UNC Disposal Site as a source for potential nitrate contamination of groundwater. There are 11,000 drums of sludge mixed among the 29,000 drums at the site. The EP toxicity analysis (Table 2) indicates that the nitrate is easily leached, and the concentration in the drummed sludges ranges from 35 to $8880 \mathrm{mg} / \mathrm{L}$, averaging $3252 \mathrm{mg} / \mathrm{L}$ as nitrogen. 
The treatment alternative has four major and individual process steps. These are solid waste processing, leaching of the nitrate from the processed waste, aqueous waste treatment, and capping. Solid waste processing on the drummed sludges results in an aqueous waste product that requires treatment. The aqueous waste will have similar characteristics to the EP toxicity data for the drummed sludge. The processed sludge and the remaining unprocessed material (drummed soil and miscellaneous scrap) will be placed back in the existing excavation and capped with a modified RCRA cap. A schematic of the treatment process is presented in Fig. 9. The details of the individual processes are described in the following sections. A summary of the nine criteria is presented in Table 25.

This alternative has not been submitted for NEPA approval. If this option is chosen as the preferred alternative, then the appropriate NEPA document must be prepared and submitted for approval. It is anticipated that this action would be applicable to a categorical exclusion, which would require $\sim 6$ months for review and approval before commencing field activities.

\subsubsection{Solid Waste Processing}

Solid waste processing involves identifying and separating the drummed sludges from the drummed soils, removing the waste from the barrels, reducing the particle size of the sludge solid waste by primary and secondary crushing, shredding empty barrels, and leaching nitrates from the crushed solid waste.

Solid waste processing of a concrete cylinder measuring $-24 \times 36$ in. requires technologies developed for use in the mining industry. These include primary and secondary crushing processes to reduce large material to a size for optimum leaching of the nitrates.

The space limitation of the UNC Disposal Site area restricts equipment size and lends itself to small mobile systems. An excavator with a drum grappling arm will perform all drum handling (unstacking) from the drum pile. The present stacking configuration requires that one full row of drums be processed at a time, starting from the top and moving down to prevent collapse of the pile. The drums will be manually deheaded to identify the contents. Many of the drums may be in such a deteriorated condition that contents may be leaking and readily observed. The drums containing soil will be dumped in the existing excavation, the empty drums shredded, and all the material set aside and temporarily covered with PVC sheeting to await disposal in the excavation by capping.

The drums identified as containing sludge will be further processed. The drums will be removed and the solid material crushed to $<9$-in.-diam pieces using a concrete pulverizer. The concrete pulverizer consists of primary crushing jaws attached to an excavator. The mobility of the concrete pulverizer allows it to move around the UNC Disposal Site to access all barrels. A front loader will be used to transport barrels of sludge/soil, primary crushed sludge, miscellaneous scrap, crushed barrels, and soil emptied from drums around the site. 


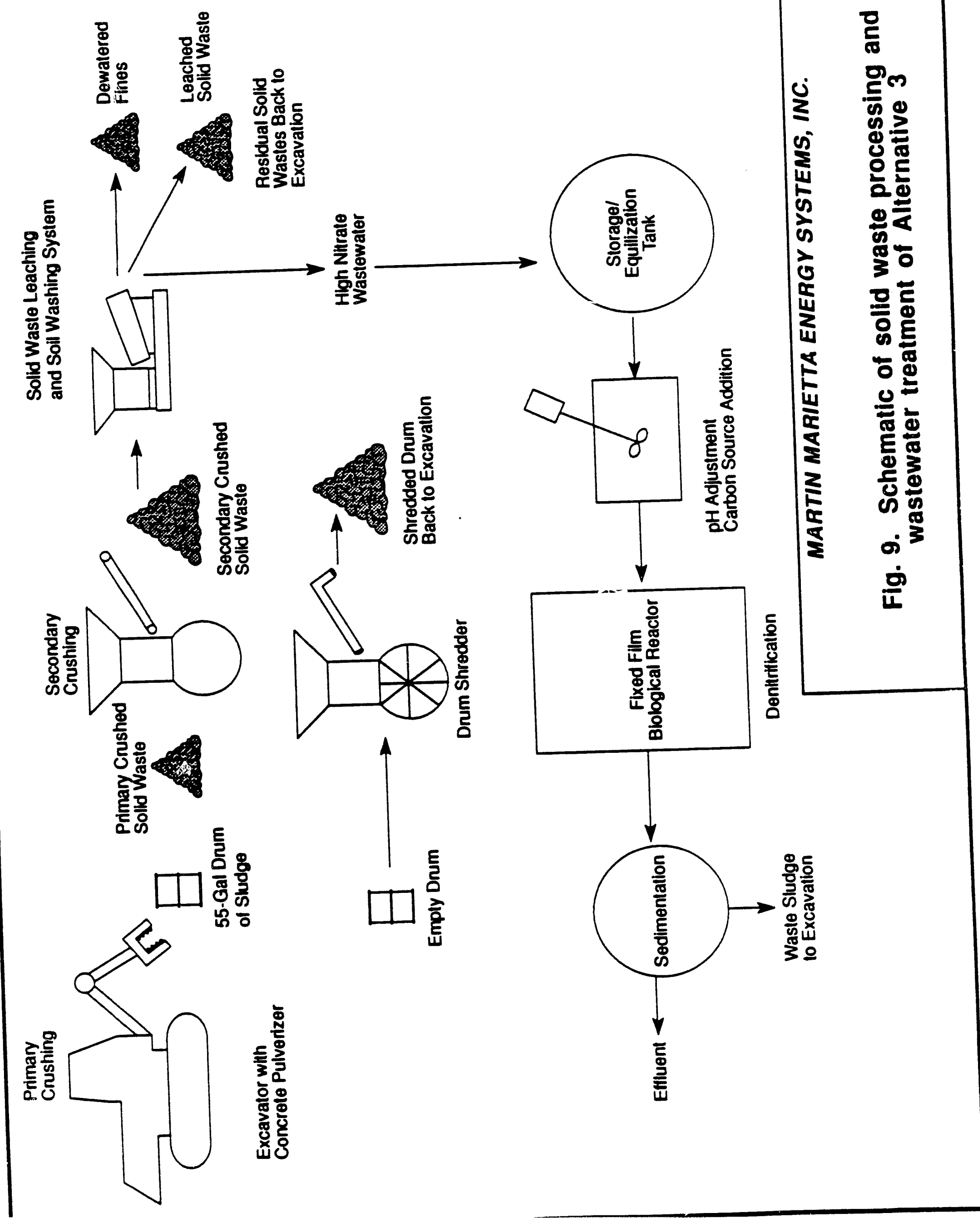


Table 25. Detailed analysis of Alternative 3: treatment and capping

Short-term effectiveness
Low short-term effectiveness due to the incriased potential for exposure to workers and the public from fugitive dusts during implementation. Engineering, design, and permitting duration: 6 months; solid waste processing and wastewater treatment duration: 16 months; capping duration: 3 months. Total time from implementation to completion: 25 months.

\section{Long-term}

effectiveness and permanence

High long-term effectiveness for removing source of potential future contamination. Nitrates are reduced in source. Residual constituents are essentially immobilized by cap. Potential nitrate contamination and strontium-90 in groundwater is remediated to below MCL.

Reduction of toxicity, mobility, and volume

Reduce toxicity, mobility, and volume of nitrate. Future potential contamination from other constituents contained through capping.

Implementability

Technically and administrativeiy feasible Requires the highest degrees of design, engineering, and planning effort of all altematives. Materials and services for the alternative are readily available. Alternative produces no restrictions on possible future remedial actions.

\begin{tabular}{|c|c|c|c|c|}
\hline \multirow{3}{*}{ Cost } & $\begin{array}{l}\text { Capital } \\
\text { costs }\end{array}$ & Anmual & $\begin{array}{l}\text { esm costs (S) } \\
\text { year(s): }\end{array}$ & $\begin{array}{c}\text { 30-year present } \\
\text { worth }(\$)\end{array}$ \\
\hline & (S) & 1 & $1-3$ & \\
\hline & $2,353,100$ & 93,600 & 69,800 & $3,033,000$ \\
\hline
\end{tabular}

Capital costs include design, engineering, and contingency allowances.

OsM costs are variable, depending on duration of component processes.

Compliance with ARARS

Chemical-specific ARARs for the potential groundwater contamination are met through containment and treatment of contaminant source. Locationand action-specific ARARs are met during implementation.

Overall protection of human health and the environment

Moderate degree of overall protection of human health and environment is provided. Potential future contamination from residual materials is effectively mitigated.

State acceptance

State acceptance of the fearures of this altemative is not known.

Community acceptance of the features of this alternative is not known. 
To facilitate nitrate leaching from the material, the primary crushed sludge will require further size reduction by a secondary crusher. Primary crushed material will be transported to the secondary crusher by a front loader. A small secondary crusher capable of reducing the material to sand consistency (if necessary) will be used. Treatability studies will be necessary to determine the optimum particle sies for nitrate leaching. Secondary crushed material will be distributed in piles by a conveyor attached to the unit.

A soil washing system will be used to leach nitrate from the secondary crushed material using aggressive separation, washing, and leaching processes developed in the mineralogical industry to remove contaminants of concern. The specific unit processes and specifications (water, energy, and detention time requirements) required would be determined using treatability studies.

The EP toxicity data indicated that nitrate is easily leached from the siudge using a slightly acidic washwater. Nitrate is highly soluble, and minor $\mathrm{pH}$ adjustment as in the EP toxicity test may not be necessary to facilitate leaching. Treatability studies will be used to determine the leaching characteristics. The system can adjust $\mathrm{pH}$ and add chemicals to the washwater to facilitate leaching if necessary. Fines will be removed from the washwater before exiting the system for treatment.

The solid waste processing (drum handling and solid waste crushing) will produce fugitive dusts requiring an air emission permit. It is estimated that the treatment would require an operating permit for $\sim 1.5$ years. Approximately 6 months is required to obtain an air emission operating permit.

All empty drums would be shredded by a metal shredder. Their shredding before capping reduces void spaces and fill requirements for the modified RCRA cap and the future chance of settling.

It is estimated that the solid waste processing and wastewater treatment would require 360 working $d$ ( 1 year, 4 months total time). This estimate assumes processing 10 drums per hour, $8 \mathrm{~h} / \mathrm{d}, 5 \mathrm{~d} /$ week.

\subsubsection{Aqueous Waste Treatment}

Wastewater generated from the soil washing system would require treatment by neutralization/pH adjustment, anaerobic fixed film treatment, and sedimentation. This wastewater treatment scheme represents historic and tested wastewater treatment technology. Treatability studies would be necessary to refine the wastewater treatment process.

Because of the short duration in which wastewater treatment is required (maximum 16 months), the wastewater treatment will be provided by a contract wastewater treatment service firm. These firms can provide mobile total wastewater treatment systems or specific 
mobile unit processes. The wastewater treatment system inciudes $\mathrm{pH}$ adjustment with acetic acid, a proprietary fixed 'ilm bioreactor, and sedimentation. The acetic acid provides $\mathrm{pH}$ adjustment and a cấroon source for denitrification.

Treated effluents from the wastewater treatment process must meet NPDES discharge criteria. The affluent from a new and intermittent discharge source is regulated under the in-place Y-12 Plant Water Management Plan. If the discharge criteria under the Y-12 Plant Water Management Plan are met, no additional permit is required. The discharge will be directed to nearby McCoy Branch or to the Y-12 Plant storm sewer, which discharges into upper EFPC.

\subsubsection{Capping}

The cap in the treatment alternative has the same performance objectives as presented in Sect. 4.2. These include minimizing liquid infiltration into the disposal area, promoting proper drainage, minimizing erosion, accommodating settling and subsidence, and ensuring isolation of the source material. The source material consists of shredded empty drums, residual leached sludge nuaterial, previously cirummed soil, miscellaneous scrap material, fines from sludge leaching, sludge from the wastewater treatment system, and dismantled wooden boxes. A detailed description of the modified RCRA cap is presented in Sect. 4.2. It is estimated construction of the cap would require 3 months. Groundwater sampling of the seven wells in the vicinity of the site will $b:$ performed quarterly the first year and semiannually thereafter.

\subsubsection{Short-Term Effectiveness}

Alternative 3 has a low short-term effectiveness because it (1) involves a significant amount of handling and processing of the drummed soil/sludges, thus increasing the potential risk to workers and the community; (2) requires a long period to implement; and (3) has air and water discharges. Solid waste processing requires a number of mechanical processing steps that generate dust. Mechanical requirements of the solid waste processing present physical risks to the workers. During the implementation of the treatment option, the workers will be required to adhere strictly to a specific health and safety plan. Risks to public health occurring during the treatment operations are unlikely due to the location of the site.

Dust emissions and surface water discharge are primary environmental effects of Alternative 3. An air emission and NPDES permit will be required for this alternative.

It is estimated that it will require $\sim 25$ months to complete this alternative, including (1) 6 months for engineering, design, and obtaining regulatory permits; (2) 16 months for separation of the drummed sludges from the drummed soils, solid waste processing, and wastewater treatment; and (3) 3 months for construction of the modified RCRA cap. The treatment of the drummed sludges and completion of the modified RCRA cap achieves the 
remedial objectives. The reduction in the contaminants of concern in the source, together with the modified RCRA cap, reduce the volume and concentration of leachate potentially migrating from the site.

\subsubsection{Long-term Effectiveness and Permanence}

As described in Sect. 4.3, the treatment option consists of three phases: solid waste processing, wastewater treatment, and emplacement of a modified RCKA cap over the residual materials. To determine the magnitude of residual risks from the treatment option, several assumptions have been made with regard to treatment of the drum contents and the modeled nitrate groundwater concentrations. The first assumption involves the efficiency of removing nitrate from the contents of the drums. A $70 \%$ efficiency is estimated in removing nitrate from the drum contents; thus the nitrate source inventory is reduced by $70 \%$.

The second assumption is that a reduction in the source inventory results in a decrease in the modeled nitrate groundwater concentration. Modeled nitrate groundwater concentration for the no-action alternative was $193 \mathrm{mg} / \mathrm{L}$ (Weston 1986). A 70\% reduction in this modeled concentration results in a nitrate value of $58 \mathrm{mg} / \mathrm{L}$ in the groundwater after 10 years. This value is the predicted (via modeling) nitrate groundwater concentration as a result of the treatment of the drummed sludge waste.

The third assumption involves further reducing the nitrate concentration in the groundwater by constructing a modified RCRA cap over the residual materials resulting from the treatment option. Modeling indicates that placing a modified RCRA cap over the untreated drums results in a nitrate groundwater concentration of $8 \mathrm{mg} / \mathrm{L}$ (Weston 1987). A nitrate concentration of $8 \mathrm{mg} / \mathrm{L}$ is a $96 \%$ reduction in the nitrate concentration when compared with modeling results for the no-action alternative (i.e., nitrate concentration of $193 \mathrm{mg} / \mathrm{L}$ ). The placement of a modified RCRA cap over residual materials left in the pit after treatment would result in a $96 \%$ reduction in the modeled nitrate groundwater concentration. This reduction in the nitrate concentration of $58 \mathrm{mg} / \mathrm{L}$ results in a nitrate groundwater concentration of $2 \mathrm{mg} / \mathrm{L}$. The treatment option coupled with emplacement of a modified RCRA cap results in a reduced nitrate groundwater concentration of $2 \mathrm{mg} / \mathrm{L}$.

Residual risks associated with the treatment option and emplacement of a modified RCRA cap over residual materials will result in a nitrate groundwater concentration of $2 \mathrm{mg} / \mathrm{L}$. The hazard quotient for this nitrate groundwater concentration is 0.04 . This value is below unity (i.e., 1), indicating that exposure to the corresponding nitrate concentration will not cause adverse health effects. No data are available on the effectiveness of the treatment option in removing strontium-90. It is assumed all of the strontium-90 will remain in residual materials left in the pit, which will be covered with a modified RCRA cap. The risks associated with modified RCRA cap concerning strontium-90 are appropriate for the treatment option. 


\subsubsection{Redustion in Taxicity, Mobility, and Volume}

It is conservatively estimated that $70 \%$ of nitrate (major containment of concern) will be removed from the drummed sludge by the treatment alternative. The drummed sludge accounts for $99 \%$ of the nitrate at the UNC Disposal Site. A reduction in volume and toxicity of the nitrate at the source is achieved. Other constituents in the waste will be essentially unchanged.

The mobility of the residual constituents in the source material is significantly reduced by the modified RCRA cap. The alternative precludes leachate products and enntamination in groundwater by lowering the water table under the site and preventing rainwalc- from percolating through the drums and boxes. Linear interpretation of the modeling dati for the modified RCRA cap indicates that a $70 \%$ reduction of nitrate in the source mate.ial would reduce potential groundwater nitrate concentrations to $2 \mathrm{mg} / \mathrm{L}$.

\subsubsection{Ease of Implementation}

The treatment option involves three individual and distinct steps: solid waste processing, wastewater treatment, and capping; thus, it requires significant engineering, design, and planning. The technology for the solid waste processing and wastewater treatment is generally available and has been demonstrated in the mineralogical and industrial wastewater treatment industry. Prior to implementation, treatability studies are required to determine the design specifications for solid waste processing and wastewater treatment. Str ctural characteristics of the solid waste, optimum particle size for leaching, leaching characteristics, and wastewater characteristics will have to be determined.

The treatment option requires an air emission permit and a NPDES discharge permit. The effluent from the wastewater treatment plant would be regulated under the Y-12 Plant Water Management Plan, which allows the plant to discharge an intermittent wastewater if it meets existing defined criteria. This policy can be implemented immediately. Fugitive dust emissions from the solid waste processing and construction aspects of the treatment option will require an emission permit. Approximately 6 months may be required to acquire an air emission operating permit.

It is estimated that it would take 25 months to complete Alternative 3. Six months would be required to develop specific design specifications, a health and safety plan, and permit requirements. The solid waste processing and wastewater treatment would require 16 months to complete. Three months would be required to construct the cap.

Potential complications and delays associated with the solid waste processing and treatment option may be weather and/or wastewater treatment-related difficulties. Extremely wet conditions would make solid waste processing difficult. Anaerobic biological processes are sensitive to cold temperatures. Efficiencies of anaerobic treatment processes are significantly decreased by cold temperatures. 
Capping, as discussed in Sect. 4.2.5, is a generally available technology that has been proven and demonstrated; furthermore, it is not difficult to implement.

\subsubsection{Cost Analysis}

The direct capital costs for this alternative incorporate costs for solid waste processing, wastewater treatment, and capping. Included in costs are treatability studies for solid waste processing and wastewater treatment. Capping incudes site preparation and construction of the cap. Indirect costs include engineering and design and a $31 \%$ contingency. The total capital cost for implementing the treatment alternative is $\$ 2,353,100$. A breakdown of these costs is presented in Appendix A, Table A.13.

All operational and maintenance costs for the 25-month period required for solid waste processing, wastewater treatment, and installation of the cap are included in the capital costs. O\&M costs after the treatment phase for the modified RCRA cap include groundwater monitoring, site inspections, mowing and revegetation, erosion control, drainage maintenance, repairs to the cap materials, and grooming equipment. Other O\&M costs include project management, insurance, and contingency costs. The estimated maintenance cost for the cap is $\$ 93,600$ for the first year and decreases to $\$ 69,800$ thereafter (Appendix A, Table A.15). The present worth O\&M costs are based on a $10 \%$ discount rate and a 30-year design life. The total present worth O\&M costs for the cap are $\$ 3,033,000$ (Appendix A, Table A.16). Details of the cost analysis are presented in Appendix A, Tables A.13 through A.18.

\subsubsection{Compliance with ARARs}

This alternative involves on-site construction activities and excavation, as well as surface water controls (Table 15), solid waste processing, biological treatment of sludges to remove nitrate, aqueous waste treatment, and return of the depleted sludge and remaining unprocessed material to the site with subsequent capping. Action-specific and locationspecific ARARs would be met at the implementation of this alternative.

Although permits are not technically required for CERCLA on-site remedial actions [CERCLA \$121(e) and FFA SXXII], it appears that pursuant to TCA 1200-3-9, a state air emission permit may be required for the fugitive emissions produced during the solid waste processing.

Permit standards for miscellaneous units, including biological treatment, are codified in 40 CFR 264.601 (See "Treatment in a Unit," Table 15). Although not applicable to this site, the substantive requirements may be considered relevant and appropriate. These standards require location, design, operation, and closure of the unit in a manner that is protective of human health and the environment. Unlike other RCRA units where the general performance objectives are achieved by specified design standards, only generalized environmental performance standards are applied to miscellaneous units. The general 
environmental performance standards require that the owner demonstrate prevention of releases to air, surface waters, or subsurface media that could have adverse effects on human health and the environment. In demonstrating compliance with these standards, the operator must consider both waste and media characteristics. For example, the demonstration for subsurface media must consider waste characteristics, the units' hydrogeologic characteristics, groundwater quality and use, relative location of groundwater withdrawal wells, and risks to plant, animal or human receptors. Eleven similar factors must be considered to demonstrate compliance with the surface water performance standard. Faciors for the air performance standard include waste characteristics, plume characteristics, reliability of the proposed treatment, atmospheric conditions, and the existing air quality.

Since tanks may be used for the nitrate leaching and aqueous wastewater treatment systems, the RCRA 40 CFR 264.190 et seq regulations are relevant and appropriate (Table 15). These regulations specify design and operating as well as inspection requirements for tanks. Tank closure and postclosure regulations are found in $40 \mathrm{CFR}$ 264.197 [TCA 1200-1-11-.06(10h)]; closure and postclosure requirements for miscellaneous treatment units are in 40 CFR 264.603 [TCÁ 1200-1-11-.06(19d)].

Subpart $\mathrm{H}$ of 40 CFR 61 addresses atmospheric radionuclide emissions from DOE facilities and may be applicable to airborne emissions during cleanup at the UNC Disposal Site. EPA has issued a final NESHAP rule $(54$ FR 51654, December 15, 1989) that limits emissions of radionuclides to the ambient air from DOE facilities to amounts that would not cause any member of the public to receive an effective dose equivalent of $10 \mathrm{mrem} / \mathrm{year}$ (40 CFR 61.92).

Following aqueous waste treatment, treated effluents may be discharged either to area surface waters or into the Y-12 Plant storm sewer. These effluent discharges are regulated by the Clean Water Act (40 CFR 122 and 125, see Table 15) and may be regulated under the NPDES permitting process of the Tennessee Water Quality Control Act (TCA 69-3-101 et seq.).

Guidance for the management of low-level radioactive waste containing no RCRA hazardous waste appears in DOE Order 5820.2A (Radioactive Waste Management, September 26, 1988). Requirements for waste treatment, shipment, disposal, and site closure/postclosure are given.

Closure of the UNC Disposal Site under this option involves the same capping requirements as are listed in Table 14. Although EPA has proposed "hybrid" closure regulations (52 FR 8712, March 19, 1987), the date for the reproposed rule-making and subsequent inal rule is unknown. Closure is considered to be closure with waste in place (since there would be some residual materials left, as well as the strontium-90, the regulations governing clean closure are not ARARs for this site). 
There is no evidence of contaminated groundwater or soil at the UNC Disposal Site, so no chemical-specific ARARs are applicable. However, groundwater modeling predicted potential contamination of groundwater to levels exceeding MCLs (Sect. 1.2.5.6). Alternative 3 , containment and treatment of the contaminant source, reduces the potential leaching of nitrate and strontium-90 to below MCL, thus ensuring compliance with MCLs.

\subsubsection{Overall Protection of Human Health and the Environment}

Alternative 3 offers a moderate degree of overall protection to human health and environment, mainly because of its low short-term effectiveness due to a long implementation period ( 25 months).

Capping secures the residual source material from direct human contact, eliminating potential impacts to human health from source material. Capping will protect the environment from potential release of contaminants from the drums and boxes. The cap minimizes infiltrating water, minimizing the only transport pathway for contaminants (groundwater).

In summary, the combination of treatment followed by capping of the residual source material reduces the volume and toxicity (concentration) of the source and then secures it from direct human and environmental contact.

\subsubsection{State Acceptance}

State acceptance of the features of Alternative 3 is not known.

\subsubsection{Community Acceptance}

Community acceptance of the features of Alternative 3 is not known.

\subsection{OFF-SITE DISPOSAL ALTERNATIVE}

The off-site disposal alternative, as developed in Sect. 3.2, involves handling and repackaģing of UNC Disposal Site wastes, transport of the repackaged wastes off-site, and disposal at an approved facility. As denoted during the development process, the preferred disposal facility is the U.S. Pollution Control land disposal facility in Beatty, Nevada. The detailed analysis and cost estimates are based on using this facility.

Handling of drums will be conducted via a drum-grappling device mounted on a large tread-driven excavating machine. This type of handling equipment minimizes personnel involvement and reduces the risk of ruptured or mishandled drums. Drums containing solidified waste will be placed in DOT-approved steel overpack drums to ensure waste packaging integrity during subsequent handling and transport. Four full-time personnel are assumed to be involved with the initial drum handling and packaging phase of this 
alternative, including one machine operator and three ground crew members positioning empty overpack drums. Demolition materials will be repackaged in 55-gal DOT approved drums or appropriate metal rrates for low-level radioactively contaminated materials. A minimum of four personnel are assumed for miscellaneous materials packaging. Due to the potential for exposure to low-level radioactivity, appropriate personal protective equipment and site monitoring will be required.

Transport of repackaged wastes is assumed to be by tractor-trailer truck. Transport vehicles, if flatbed trailers are used, may be loaded through the use of the drum grappling device, placing repackaged wastes on pallets, and loading with a forklift. If enclosed trailers are used, a loading dock and staging area will be required, repackaged waste will be placed on pallets, and loading will be conducted via a forklift. A staging area used during placement of the drums still exists at the site; it may be repaired if necessary and used. Transport distance from the Y-12 Plant to the assumed disposal facility is -2100 miles. Assuming standard trailer dimensions of $40 \mathrm{ft}$ by $10 \mathrm{ft}$, overpack diameter of $30 \mathrm{in}$., and that overpacks stacked in two layers (total height of $\sim 100 \mathrm{in}$.), a minimum of $\sim 120$ repackaged drums could be hauled per truckload. Assuming, however, that the weight of each overpack is $850 \mathrm{lb}$, each truckload would weigh $\sim 100,000 \mathrm{lb}$, exclusive of the trailer weight, which is more than the $80,000 \mathrm{lb}$ single-trailer transport weight restriction imposed by most states (Wagner et al. 1987). Based on the weight restrictions, 80 drums per truck load is used for estimating costs. This results in a truckload weight of $\sim 68,000 \mathrm{lb}$, exclusive of trailer weight. Transport of all the drums now stored at the UNC Disposal Site would require $\sim 365$ truckloads based on those assumptions. Demolition materials constitute an approximate additional volume of waste of $1100 \mathrm{yd}^{3}$, assuming crate dimensions of $5 \mathrm{ft}$ wide, $5 \mathrm{ft}$ long, and $4 \mathrm{ft}$ high $\left(100 \mathrm{ft}^{3}\right)$. Based on the previously described dimensions for an 85-gal drum, an additional 1800 drums ( 23 truckloads) would be required to repackage demolition materials for transport. Transport of wastes would be subject to applicable DOT and state regulations. Once the wastes are removed, 48 soil samples for TCLP analyses will be taken from the floor of the excavation (pit) to confirm the floor soil is not contaminated (16 samples per sampling depth at ground surface, $5 \mathrm{ft}$, and $10 \mathrm{ft}$ below ground surface). After confirmation, the site will be backfilled with clean soil and returned to a natural state. Quarterly groundwater monitoring by Y-12 Plant personnel during the first year following completi $n$ of the alternative with semiannual groundwater monitoring for an additional 2 years is assumed. A summary of the nine criteria is presented in Table 26.

This alternative has not been submitted for NEPA approval. If this option is chosen as the preferred alternative, then the appropriate NEPA document must be prepared and submitted for approval. It is anticipated that this action would be applicable to a categorical exclusion which would require $\sim 6$ months for review and approval before commencing field activities. 
Table 26. Detailed analysis of Alternative 4:

off-site disposal

\begin{tabular}{|c|c|}
\hline $\begin{array}{l}\text { Short-term } \\
\text { effectiveness }\end{array}$ & $\begin{array}{l}\text { Low to moderate short-term effectiveness due to hardling and repackaging of } \\
\text { wastes. Increased risk of exposure to site workers from fugitive dusts or } \\
\text { accidental ingestion. Injury risk present due to drums handling and packaging of } \\
\text { miscellaneous wastes. Alternative duration: } 12 \text { months. }\end{array}$ \\
\hline $\begin{array}{l}\text { Long-term } \\
\text { effectiveness and } \\
\text { permanence }\end{array}$ & $\begin{array}{l}\text { High degree of long-term effectiveness because wastes are removed from site. } \\
\text { Residual risks are negligible given that soil or groundwater contamination has not } \\
\text { occurred. Long-term management at the disposal facility will be conducted as } \\
\text { part of an overall facility plan. }\end{array}$ \\
\hline $\begin{array}{l}\text { Reduction of toxicity, } \\
\text { mobility, and volume }\end{array}$ & $\begin{array}{l}\text { Alternative reduces mobility of contaminants from the waste through proper } \\
\text { containment and disposal. Toxicity of wastes is not reduced; however, the } \\
\text { potential for exposure will decrease substantially. Volume of material to be } \\
\text { transported and cisposed will increase due to repackaging. }\end{array}$ \\
\hline Implementability & $\begin{array}{l}\text { Technically feasible. Requires considerably more design and planning effort than } \\
\text { nc action but less than capping or treatment. Materials and services for the } \\
\text { alternative are readily available. Alternative produces no restrictions on any } \\
\text { future remedial actions at the UNC Disposal Site. }\end{array}$ \\
\hline Cost & $\begin{array}{l}\text { Total capital costs including design, engineering, and contingency allowances: } \\
\$ 13,954,000 \text {. } \\
\text { Total annual O\&M costs are variable depending on the duration of component } \\
\text { process options: year } 1: \$ 63,000 \text {; years } 2-4: \$ 39,000 \text {; } \\
\text { 4-year present worth: } \$ 14,073,000 \text {. }\end{array}$ \\
\hline $\begin{array}{l}\text { Compliance with } \\
\text { ARARs }\end{array}$ & $\begin{array}{l}\text { Alternative complies with action-specific and location-specific ARARs. } \\
\text { Contaminant levels are not actually reduced; however, the degree of } \\
\text { immobilization provided by proper packaging and disposal reduces long-term } \\
\text { exposure risks. Chemical-specific ARARs for the potential groundwater } \\
\text { contamination are met through removal of source of potential contamination from } \\
\text { site. }\end{array}$ \\
\hline $\begin{array}{l}\text { Overall protection of } \\
\text { human health and } \\
\text { the environment }\end{array}$ & $\begin{array}{l}\text { Moderate degree of overall protection of human health and the environment. } \\
\text { Wastes removed from site. Contaminants are immobilized through containment } \\
\text { and disposal. Short-term effectiveness considerations reduce overall performance. }\end{array}$ \\
\hline State acceptance & State acceptance of the features of this alternative is not known. \\
\hline $\begin{array}{l}\text { Community } \\
\text { acceptance }\end{array}$ & $\begin{array}{l}\text { Community acceptance of the features of this altemative is not available now. } \\
\text { Energy Systems and DOE acceptance is contingent on policy for off-site waste } \\
\text { shipment. }\end{array}$ \\
\hline
\end{tabular}




\subsubsection{Short-Term Effectiveness}

The off-site disposal alternative has a low to moderate short-term effectiveness when considering potential exposure of plant personnel to contaminants or the risk of injury while repackaging operations are ongoing. Although appropriate safety precautions would be enforced and mechanized equipment used to the extent possible, the potential for drum ruptures and falling or sliding drums will exist. Miscellaneous waste materials will have to be dealt with largely by hand, thereby further increasing the risk of injury or exposure. Also, some portion of solidified wastes that have spilled from deteriorated drums will require handling and packaging by hand. Repackaging of uncontained or spilled wastes and the potential for drum rupture increase the risk of fugitive dusts and emissions and consequently exposure of personnel.

The time required for implementation (12 months) assumes that 80 drums of solidified wastes can be repackaged per day by a crew of four personnel. The crew would consist of a drum-grappler device operator and three ground crew members. Additional personnel may be required for repackaging miscellancous wastes.

\subsubsection{Long-Term Effectiveness}

The off-site disposal alternative has a high degree of long-term effectiveness with regard to the UNC Disposal Site because wastes will be removed from the area. As such, residual risks will be negligible given that contamination of soil and groundwater has not occurred at the site. Removal of waste from the site results in no required long-term site management controls. Long-term management of wastes at the disposal facility would be part of an overall facility plan, and the UNC wastes are not expected to pose significant management difficulties or impact reliability of controls.

\subsubsection{Reduction of Toxicity, Mobility, and Volume}

Proper repackaging and disposal of the UNC Disposal Site wastes would reduce mobility of contaminants through eliminating contact with mobilization agents, such as water and air. Toxicity of the waste would not be reduced; however, exposure risks to human and environmental receptors would be decreased. The volume of material requiring disposal would increase due to overpacking of drums and repackaging of miscellaneous wastes in containers smaller than those now used.

\subsubsection{Ease of Implementation}

The off-site disposal alternative is readily implemented from a technical standpoint. Complex treatment systems used in other process options are not incorporated into the alternative. Because wastes are removed from the site, the reliability of mit_sation technologies and the ease of undertaking future actions is not applicable. Services and materials required for the alternative are readily available. Administrative requirements with 
regard to off-site shipment of low-level radioactively contaminated materials will place significant restrictions on this alternative. Approval for off-site transport and disposal would be required from DOE and other appropriate agencies before implementation.

\subsubsection{Cost Analysis}

The estimated capital cost for off-site disposal is $\$ 13,954,000$, including materials purchases, transport, and disposal fees. Annual operation and maintenance costs of $\$ 63,000$ for the first year and $\$ 39,000$ for the second and third years following completion consist of sampling labor and analytical costs. Costs reflect quarterly monitoring for the first year and semiannual groundwater monitoring by the Y-12 Plant for an additional 2 years after backfilling for verification of no residual contamination.

\subsubsection{Compliance with ARARs}

This alternative involves handling and repackaging of the UNC Disposal Site wastes, transport of the packaged wastes off-site, and disposal at an approved facility. It is assumed that the waste will be immediately loaded into trucks for transport, with no temporary accumulation in the area. The wastes will be transported by a permitted transporter and carried to a RCRA-permitted racility. Action-specific and location-specific ARARs are met at the time of implementation of aiternative.

On-site construction/excavation and surface water control will be similar to the other alternatives (Table 14). The next procedure in this action is transporting the contaminant drums off-site for tre?tment (Table 16). Any generator that transports or offers for transportation hazardous waste for off-site treatment, storage, or disposal, must prepare a manifest. The waste must be packaged in accordance with Department of Transportation (DOT) regulations codified in 49 CFR Parts 175, 178, and 179 (Table 16). In addition to the manifest and pretransport requirements detailed in Subparts B and C of 40 CFR 262, standards for labeling, marking, and placarding that are stated in 49 CFR Part 172 must be met.

The landfill to which DOE transports the treated waste must meet the minimum requirements of 40 CFR 264. The facility in Beatty, Nevadr meets these standards. Additionally, under Sect. 121(d)(3) of CERCLA, off-site disposal facilities must be in compliance with requirements established pursuant to RCRA 3004(u), 3004(v), or 3008(h).

The NRC has promulgated licensing requirements for: land disposal of radioactive waste (10 CFR 61). Part 61 contains procedural requirements and performance standards applicable to any method of land disposal, with specific technical requirements for nearsurface disposal of radioactive waste. In addition, the radiation protection standards of 10 CFR 20.101 limit worker exposures in restricted areas to $1.25 \mathrm{rem} /$ quarter. Although not legally applicable to DOE facilities, these regulations may be relevant and appropriate for workers handling and repackaging the strontium-90 contaminated materials. 
Closure of the UNC Disposal Site will involve backfilling with clean soil and a return to a natural state. The RCRA clean closure regulations may be relevant and appropriate for this activity (Table 16).

There is no evidence of contaminated groundwater or soil at the UNC Disposal Site, so no chemical-specific ARARs are applicable. However, groundwater modeling predicted potential contamination of groundwater to levels exceeding MCLs (Sect. 1.2.5.6). Chemicalspecific ARARs for potential groundwater contamination are met through removal of source of potential contamination.

\subsubsection{Overall Protection of Human Health and the Environment}

The technical requirements, short- and long-term effectiveness considerations, and lack of reductions of toxicity and volume of wastes result in a moderate overall degree of human health and environmental protection. Waste repackaging and long-distance transport increase the risk of exposure of human and environmental receptors. Wastes removed from the UNC Disposal Site will place an additional load on the resources of the disposal facility. Because the wastes are contained and not treated, toxicity levels are not decreased; hence, a possibility that they present a future environmental hazard cannot be eliminated.

\subsubsection{State Acceptance}

No specific comments regarding the components are now available. The assumption is made that the alternative is acceptable contingent on adherence to applicable state guidelines regarding monitoring of site personnel, site monitoring during waste repackaging, and transport of the wastes.

\subsubsection{Community Acceptance}

No specific public comments concerning the components of the alternative are available. Acceptance of this alternative by DOE or Energy Systems is contingent on policies for transport of wastes off DOE ORR.

\subsection{SUMMARY AND COMPARISON OF ALTERNATTVES}

The purpose of the comparative analysis is to weigh the advantages and disadvantages of the alternatives compared with each other and to the nine criteria used in the detailed assessment. This procedure is in contrast to the individual examinations, which analyzed each alternative separately, giving little consideration to interrelationships between them. The comparative analysis allows for identification of items that can be evaluated by the decision-making party during the final selection. Short- and long-term effectiveness; toxicity, mobility, and volume reductions; ease of implementation; and costs rece ive the greatest consideration, whereas overall protection and compliance with ARARs are generally examined as threshold determinations in that they must be met by any alternative for it to 
be eligible for selection. State and community acceptance should be considered only as a preliminary assessment at this time. A comparison of the nine criteria and the four alternatives is presented in Table 27.

\subsubsection{Short-Term Effectiveness}

The complexity of the alternative typically results in decreased short-term effectiveness because of increased handling and processing associated with it. Alternative 1, no action, provides the greatest degree of protection to workers, the public, and the environment because the source material is left undisturbed. The drummed soil/sludges and miscellaneous scrap are treated or isolated with a minimum of excavation and handling, resulting in minimal fugitive dust release, no transport risk, and minimized increases in surface erosion potential due to disturbance by heavy equipment and extensive excavation. Alternative 1 requires the shortest time to implement. The short-term effectiveness decreases in the alternatives in the following order: 2, 4, and 3. Alternative 2, capping, will require little handling or movement of the drums or boxes. Once the initial layer of fill material is deposited, the source material will be isolated from the workers. Dust will be generated by the earth-moving aspects of the alternative.

Alternative 4, off-site disposal, requires handling of the drums and miscellaneous scrap. Once a drum is overpacked, it is isolated from the worker. The drums are in poor condition and many may fail when handled, resulting in exposure of the contents to workers and the environment.

Alternative 3, treatment and capping, has the highest degree of short-term risks and requires the longest time to complete ( 25 months). Extensive handling ar 4 movement of the drums is required. The drums have to be unstacked, the contents removed and separated, and drummed sludge mechanically crushed and leached. These steps will result in potential health risks to workers. The fugitive dusts produced from mechanical processing of solid waste may have high concentrations of nitrate and radioactive contaminants.

\subsubsection{Long-Term Effectiveness and Permanence}

Human health risks after remediation give an indication of the long-term effectiveness of an alternative. Human health risks due to exposure to groundwater, surface water, and soils are reduced from the existing risk by varying degrees, depending on the degree of treatment provided by the alternatives. Site-specific risk values of the remedial target concentrations are presented in the detailed analysis tables. 


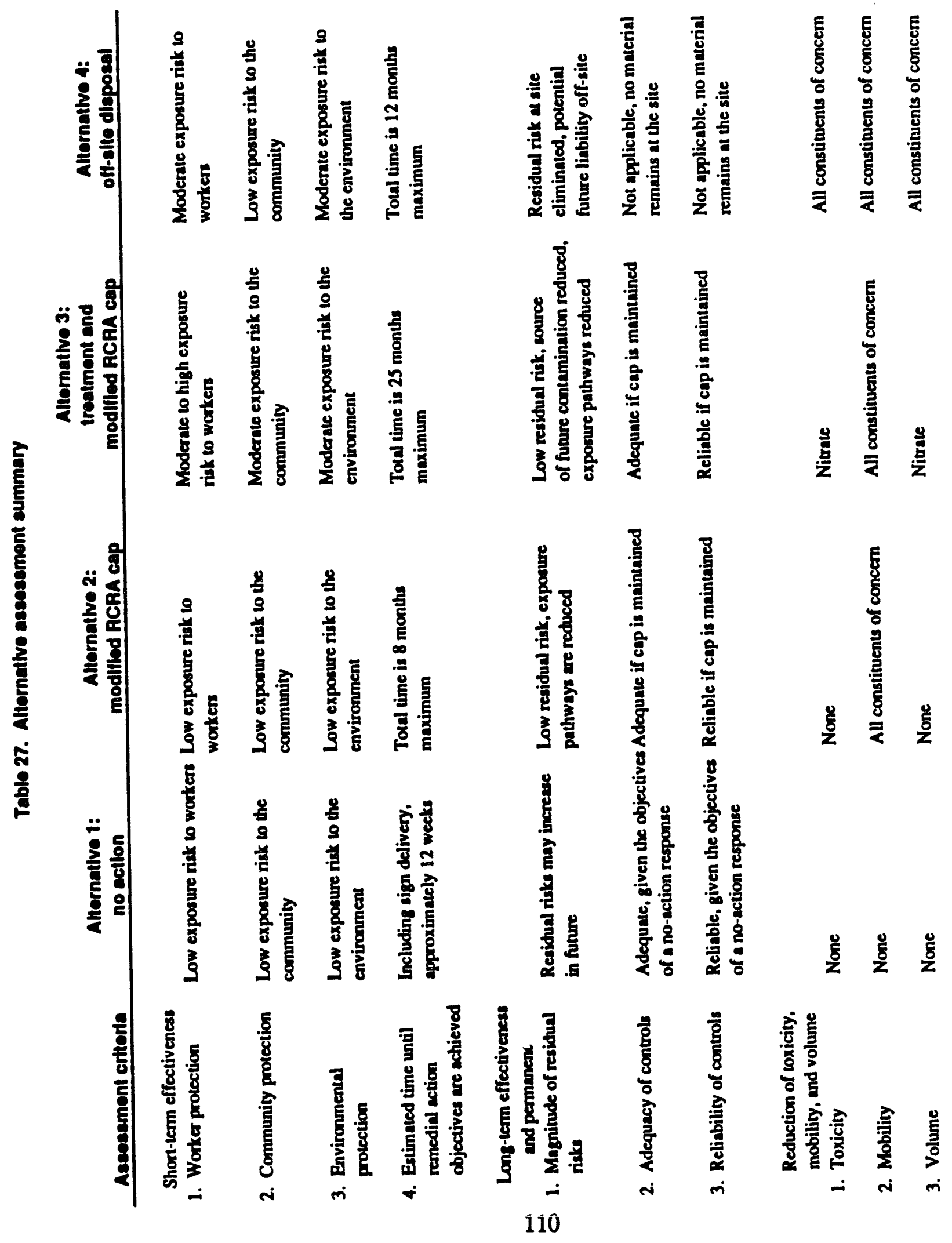




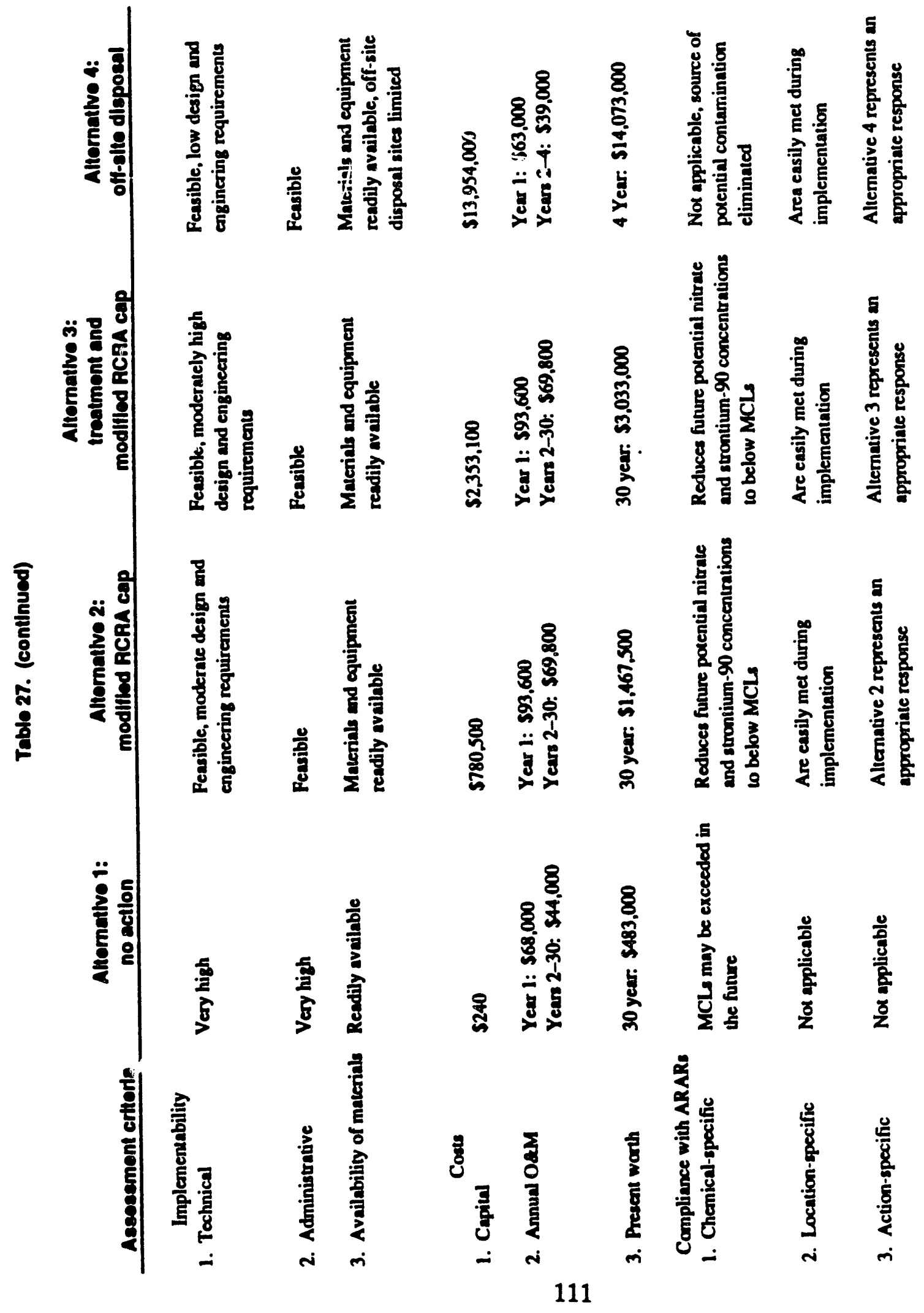




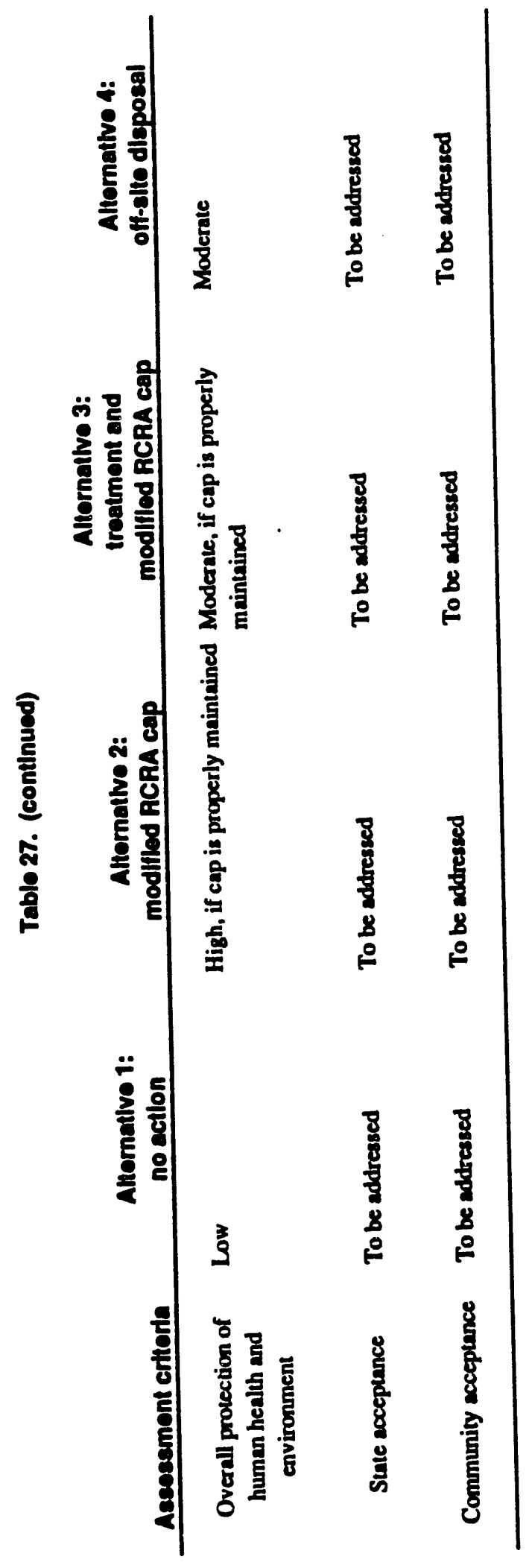


Alternative 1, no action, has a low long-term effectiveness because the postimplementation residual risks are equal to those now at the sites. In consideration of the objectives of the no-action response, both the remoteness of the site and the secured nature of the site should minimize the risk of direct contact with drummed soils/sludges and miscellaneous scrap. The implementation of a monitoring program at existing wells should suffice to evaluate contaminant migration.

Alternative 2, capping, and Alternative 3, treatment and capping, have high degrees of long-term effectiveness and permanence. Both alternatives result in modeled nitrate groundwater concentration having hazard quotients (HQs) $<1$; thus, noncarcinogenic adverse health effects are not expected. Neither alternative reduces strontium-90 in the UNC Disposal Site. Both use capping to reduce infiltration of precipitation and depend on cap integrity for effectiveness and permanence.

Alternative 4, off-site disposal, offers the highest degree of long-term effectiveness and permanence. The drummed soil/sludge and miscellaneous scrap are transported off-site to a treatment and disposal facility. No source material remains at the site for potential future risks.

\subsubsection{Reduction of Toxicity, Mobility, and Volume}

Alternative 1, no action, does not reduce the toxicity, mobility, or volume of contaminants. The human health risks of nitrate and strontium-90 associated with the potential migrations of nitrate and strontium to groundwater under no action were presented in Sect. 1.3. The no-action alternative predicts $193 \mathrm{mg} / \mathrm{L}$ of nitrate in the groundwater, resulting in a hazard quotient for nitrate of 3.4. Hazard quotients $>1$ indicate the nitrate concentration in groundwater may cause adverse noncarcinogenic health effects. The modeled strontium-90 concentration of $50 \mathrm{pCi} / \mathrm{L}$ is predicted for the no-action alternative. The risk level for this concentration is $8.3 \mathrm{E}-5$, which is within EPA's range of concern (1.0E4 to $1.0 \mathrm{E}-6)$.

Alternative 2, the capping alternative, reduces the mobility of constituents of concern through reduced infiltration. Some migration remains possible if the cap is not properly maintained. Capping reduces the concentration of nitrate and strontium- 90 potentially migrating to the groundwater to $8 \mathrm{mg} / \mathrm{L}$ and $2 \mathrm{pCi} / \mathrm{L}$, respectively. The hazard quotient for this nitrate concentration is $0.14(<1)$, indicating that capping reduces the nitrate concentration to a level that will not cause adverse health effects. The risk associated with $2 \mathrm{pCi} / \mathrm{L}$ is $3.3 \mathrm{E}-6$, which is still in EPA's range of concern but lower than the risk associated with no-action alternative.

Alternative 3, treatment of the drummed sludge and capping, reduces the toxicity and volume of the nitrate in the source material. Capping reduces the mobility of the remaining inorganic constituents in the drummed sludge, drummed soil, and miscellaneous scrap. The treatment alternative reduces the potential nitrate groundwater concentration to $2 \mathrm{mg} / \mathrm{L}$. 
This figure corresponds to a hazard quotient of 0.04 . This value indicates that exposure to the corresponding nitrate concentration will not cause adverse health effects. Risks associated with strontium- 90 will be reduced to the same level as Alternative 2, capping.

Alternative 4, off-site disposal, eliminates the toxicity, volume and potential mobility of the constituents of concern in the source material but transfers the material somewhere else.

\subsubsection{Ease of Implementation}

The design, engineering, and administrative requirements associated with Alternative 1, no action, are essentially negligible. Materials required for the components of this alternative are readily available. The remaining alternatives are all technically and administratively feasible. The engineering and design requirements increase with the complexity of the alternatives in the following order: Alternative 2, capping; Alternative 4, off-site disposal; and Alternative 3, treatment and capping.

Materials and services for the various alternatives are readily available. The cap design of Alternative 2 is easily implemented. Similar cap designs have been installed at the Y-12 Plant. Materials and services are available locally.

Alternative 3 has the highest degree of difficulty to implement because of engineering, design, and administrative requirements. Alternative 3 combines tested and available technologies to achieve the treatment, but their combination has high engineering demands.

Alternative 4 has high administrative requirements because of the large volume of material to be transported off-site.

\subsubsection{Costs}

The comparative analysis of costs discusses only differences in capital, operation and maintenance, and present worth values. Costs for each alternative have been provided in detail in Appendix A, Tables A.1 - A.4. Itemization of individual components and the sensitivity analysis for each alternative may be found in Appendix A. The costs increase with the complexity of the alternative and the volume of contaminant to be treated. The noaction alternative has the lowest costs followed by Alternative 2, Alternative 3, and Alternative 4.

\subsubsection{Compliance with ARARs}

Since there is no evidence of contaminated groundwater or soil, there are no chemical-specific ARARs for cleanup at the UNC Disposal Site. However, based on simulations representing an uncapped, exposed excavation, the potential exists for contamination of groundwater to levels exceeding SDWA MCLs. With the exception of the 
no-action alternative, the other three alternatives selected would minimize the potential leaching of contaminants into groundwater, thus ensuring compliance with the MCLs.

Alternative 1, no action, would preclude compliance with chemical-specific ARARs. Although no chemical-specific ARARs are applicable at this time, given the potential (modeled) for groundwater contamination, this alternative would not comply with SDWA MCLs. Action-specific and location-specific ARARs are not applicable to the no-action alternative.

Alternative 2, capping, would be in compliance with all action-specific ARARs at the time of implementation. Surface water runoff controls would avoid any impact on adjacent streams, and fugitive dust emission control would reduce any impact on the adjacent Fanny Hill reference area (Sect. 2.3.2). Therefore, compliance with location-specific ARARs will also be met by this alternative.

Alternative 3, treatment and capping, will be in compliance with all location- and action-specific ARARs during implementation. Alternative 3 would consply with chemicalspecific ARARs given the potential for future groundwater contamination as predicted by modeling.

Alternative 4, off-site disposal, will comply with location- and action-specific ARARs. Chemical-specific ARARs are met by removal of the source of potential contamination.

\subsubsection{Overall Protection of Human Health and the Environment}

Alternative 1, no action, has the lowest degree of overall protection of human health and environment of the alternatives because of its low long-term effectiveness and its potential future noncompliance with ARARs. Alternative 2, capping, offers the highest degree of protection of human health and the environment of the alternatives because it requires minimal disruption of the site to affect short-term effectiveness, has a high degree of long-term effectiveness, and fully complies with ARARs. Alternative 3, treatment and capping, and Alternative 4, off-site disposal, offer moderate degrees of overall protection of human health and the environment because of their low degrees of short-term effectiveness due to significant handling and processing of the waste and potential exposure to the environment.

\subsubsection{State Acceptance}

No specific comments regarding the components of these alternatives are now available. 


\subsubsection{Community Acceptance}

Community acceptance of these alternatives is not now known. Community viewpoints will be addressed during public review and comment. 


\section{REFERENCES}

Bailey, J. K., Jones, L. S., and Williams, J. L. 1989. Closure Plan for the United Nuclear Corporation Waste Disposal Site, Martin Marietta Energy Systems, Inc., Oak Ridge Y-12 Plant, Oak Ridge, Tennessee (Y/LA-200).

Beljin, M. S. 1985. A Program Package of Analytical Models for Solute Transport in Groundwater, International Groundwater Modeling Center, Holcomb Research Institute, Indianapolis, Indiana.

Cadwallader, M. W. 1986. "Synthetic Flexible Membrane Liners in Waste Disposal Facilities: Guidelines for Proper Selection, Specification, and Compliance with Government Regulations." Hazpro '86 Conference, Baltimore, Maryland.

Cadwallader, M. W. 1987. "Durable Liners for Hazardous Waste Containment." World Conference on Hazardous Waste, Budapest, Hungary.

Cox, W. C. 1990. O-Wing Safety Analysis Report, Chapter 3. Site Description, Y-12 Plant, Building 9215, Martin Marietta Energy Systems, Inc., Oał Ridge Y-12 Plant, Oak Ridge, Tennessee.

Early, T. D. 1989. Proposed Groundwaier Monitoring Plan for the United Nuclear Corporation Waste Disposal Site at the Y-12 Plant, Martin Marietta Energy Systems, Inc., Oak Ridge National Laboratory, Environmental Sciences Division, Oak Ridge, Tennessee (Y/T-530/1).

Energy Systems (Martin Marietta Energy Systems, Inc.). 1990a. Risk Assessment for UNC Disposal Site, Office of Risk Analysis, Oak Ridge National Laboratory, Oak Ridge, Tennessee.

Energy Systems (Martin Marietta Energy Systems, Inc.). 1990b. Personal communication between Ray Moore, Y-12 Environmental Restoration Division, Oak Ridge, Tennessee, and Jeff Longaker, Science Applications International Corporation, Oak Ridge, Tennessee.

Freeze, R. A., and Cherry, J. A. 1979. Groundwater, Prentice-Hall, Inc.

GEOTEK Engineering Company. 1982. Subsurface Investigation and Monitoring Wells for Proposed Waste Disposal Area on Chestnut Ridge at the Y-12 Plant (Y/SUB/82-24700/2).

Geraghty and Miller. 1990. Groundwater Quality Assessment for the Chestnut Ridge Security Pits Hazardous Waste Disposal Unit at the Y-12 Plant (Y/SUB/90-00206C/3).

Geswein, A. J. 1975. Liners for Land Disposal Sites: An Assessment, U.S. Environmental Protection Agency (EPA/530/SW-137). 
Haase, G. S., King, H. L., Gillis, G. A., Kimbrough, C. W., and Mercier, T. M. 1987 a. Preliminary Analysis of Groundwater Data for the United Nuclear Site at the Y-12 Plant, Oak Ridge, Tennessee, Martin Marietta Energy Systems, Inc., Oak Ridge National Laboratory, Oak Ridge, Tennessee (Y/T-270).

Haase, C. S., et al. 1987b. Subsurface Database for Bear Creek Valley, Chestnut, and a Portion of Bethel Valley on the U.S. Department of Energy Oak Ridge Reservation, Martin Marietta Energy Systems, Inc., Oak Ridge National Laboratory, Oak Ridge, Tennessee (ORNL/TM-10000).

Ketelle, R. H., and Huff, D. D. 1984. Site Characterization of the West Chestnut Ridge Site, Marietta Energy Systems, Inc., Oak Ridge National Laboratory, Oak Ridge, Tennessee (ORNL/TM-9229).

King, H. L., and Haase, C. S. 1987. Subsurface-Controlled Geologic Map for the Y-12 Plant and Adjacent Area of Bear Creek Valley, Martin Marietta Energy Systems, Oak Ridge National Laboratory, Oak Ridge, Tennessee (ORNL/TM-10112).

Kirkpatrick, C. R., and McCall, J. S. 1986. Analytical Support for the United Nuclear Waste Program - Final Report, Martin Marietta Energy Systems, Inc., Oak Ridge Y-12 Plant, Oak Ridge, Tennessee (K/PS-1207).

Levin, M.B., et al. 1989. Integrating NEPA and CERCLA Requirements During Remedial Responses at DOE Facilities. Martin Marietta Energy Systems, Inc., Oak Ridge National Laboratory, Oak Ridge, Tennessee, October.

Lutton, R. J. 1987. Design, Construction, and Maintenance of Cover Systems for Hazardous Waste: An Engineering Guidance Document, U.S. Environmental Protection Agency, Office of Research and Development, Cincinnati, Ohio (EPA/600/2-87/039).

McMaster, W. A. 1962. Geologic Map, Oak Ridge Area, U.S. Geological Survey in Cooperation with the U.S. Atomic Energy Commission, February.

Moneymaker, R. H. 1981. Soils Survey of Anderson County, Tennessee, U.S. Department of Agriculture-Soil Conservation Survey, Washington, D.C.

Oak Ridge National Laboratory. 1990. UNC Waste Disposal Site Risk Assessment, Martin Marietta Energy Systems, Inc., Oak Ridge, Tennessee.

Scarbrough, J. H. 1990. Correspondence to R. C. Sleeman, Environmental Restoration Division, Martin Marietta Energy Systems, Inc., Oak Ridge, Tennessee.

U.S. EPA. 1985a. National Oil and Hazardous Substances Pollution Contingency Plan: Final Rule, Federal Register 50:47912-47979. 
U.S. EPA. 1977. Liner Materials Exposed to Hazardous and Toxic Sludges, U.S. Environmental Protection Agency (EPA/600/2-77/081).

U.S. EPA. 1988. Guidance for Conducting Remedial Investigations and Feasibility Studies Under CERCLA: Interim Final, U.S. Environmental Protection Agency, Office of Emergency and Remedial Response, Washington, D.C. (EPA/540/6-89/004).

U.S. EPA. 1989a. Correspondence, R. Spence, Department of Energy Oak Ridge Operations, Oak Ridge, Tennessee.

U.S. EPA. 1989b. Risk Assessment Guidelines for Superfund: Volume 1, Human Health Evaluation Manual (Part A) Interim Final, U.S. Environmental Protection Agency, Office of Emergency and Remedial Response, Washington, D.C. (EPA/540/1-89/002).

U.S. EPA. 1990. Integrated Risk Information System (IRIS), U.S. Environmental Protection Agency, Office of Health and Environmental Assessment, Washington, D.C. (searched July 1990).

Wagner, K. 1987. Drum Handling Manual for Hazardous Waste Sites, Noyes Data Corporation, Park Ridge, New Jersey.

Weston, R. F. 1986. Pathways Analysis for UNC Disposal Pit Y-12 Plant, Martin Marietta Energy Systems, Inc., Oak Ridge Y-12 Plant, Oak Ridge, Tennessee (Y/SUB/86-22264/1).

Weston, R. F. 1987. Results of Computer Simulations for Alternative Closure Options: UNC Disposal Pit, Martin Marietta Energy Systems, Inc., Oak Ridge Y-12 Plant, Oak Ridge, Tennessee [Y/SUB-86-22264/1 (Appendum)].

Weston, R. F. 1990. Draft Results of Hydrologic Impact Modeling of Strontium-90 Migration for the UNC Waste, Martin Marietta Energy Systems, Inc., Oak Ridge Y-12 Plant, Oak Ridge, Tennessee. 


\section{APPENDIX A}

\section{COST ANALYSIS}


Table A.1. Altemative 1: no-action,

capital cost

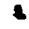

\begin{tabular}{|c|c|c|c|}
\hline $\begin{array}{c}\text { Cost } \\
\text { component }\end{array}$ & $\begin{array}{c}\text { Cost } \\
\text { estimate }\end{array}$ & $\begin{array}{l}\text { Basis of } \\
\text { estimate }\end{array}$ & $\begin{array}{l}\text { Year } \\
\text { incurred }\end{array}$ \\
\hline \multirow{2}{*}{\multicolumn{4}{|c|}{$\begin{array}{l}\text { Direct capital costs } \\
\text { 1. Construction costs } \\
\text { a. Equipment } \\
\text { b. I. jor } \\
\text { c. Maturials Subtoul } \\
\text { 2. Equipment costs } \\
\text { - Installed } \\
\text { - Purchased }\end{array}$}} \\
\hline & & & \\
\hline & & & \\
\hline $\begin{array}{l}\text { 5. Relocation coses } \\
\text { Subtocal }\end{array}$ & & & \\
\hline $\begin{array}{l}\text { 6. Dispocal coests } \\
\text { Subcoul }\end{array}$ & & & \\
\hline Toeal direct coses & 151 & & 0 \\
\hline $\begin{array}{l}\text { Indirect capital costs } \\
\text { 1. Engineering and design }\end{array}$ & 38 & $25 \%$ of toeal direct $\cos { }^{*}$ & \\
\hline 2. Contingency allowance & 47 & $31 \%$ of tocal direct cost* & 0 \\
\hline $\begin{array}{l}\text { a. Legal fees } \\
\text { b. License/permit costs } \\
\text { c. Start-up and shake Jown }\end{array}$ & & & \\
\hline TOTAL INDIRECT COSTS & 85 & & 0 \\
\hline TOTAL CAPITAL COSTS & 240 & & 0 \\
\hline
\end{tabular}

Reference: Energy Systems.

A-3 
Table A.2. Alternative 1: no action,

basis of capital cost estimate

\section{COST ITEM: _ Pirect-Construction Costs}

BASIS: No-Action Alternative - Procurement and Installation of

4 signs $\left(4 \mathrm{ft}^{2}\right)$. Signs are of steel construction and

reflectorized

CALCULATION/SOURCE: $\frac{\text { LABOR: } \$ 6.93 / \text { sign installation } \times 4 \text { signs }}{=\$ 27.72}$

MATERIALS: $\$ 30.61 / \mathrm{ft}^{2}$ of sign $\times 4$ signs $=\$ 122.44$

SOURCE: Dodge Unit Cost Darn, 1988

DOL Employment and Earnings, 1988

Vendor Estimates

$\dot{A}-\hat{4}$ 
Table A.3. Alternative 1: no-action,

annual operating costs

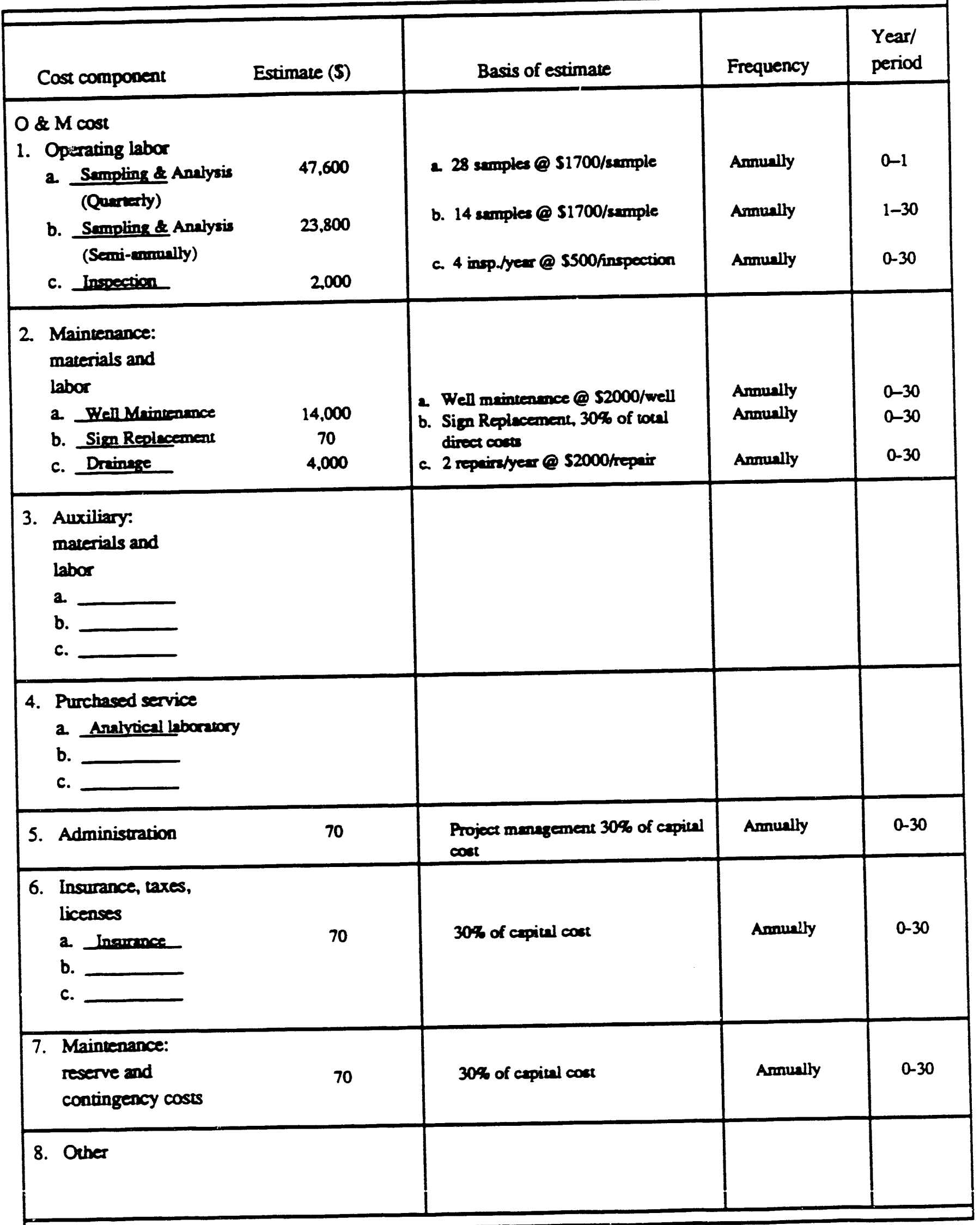



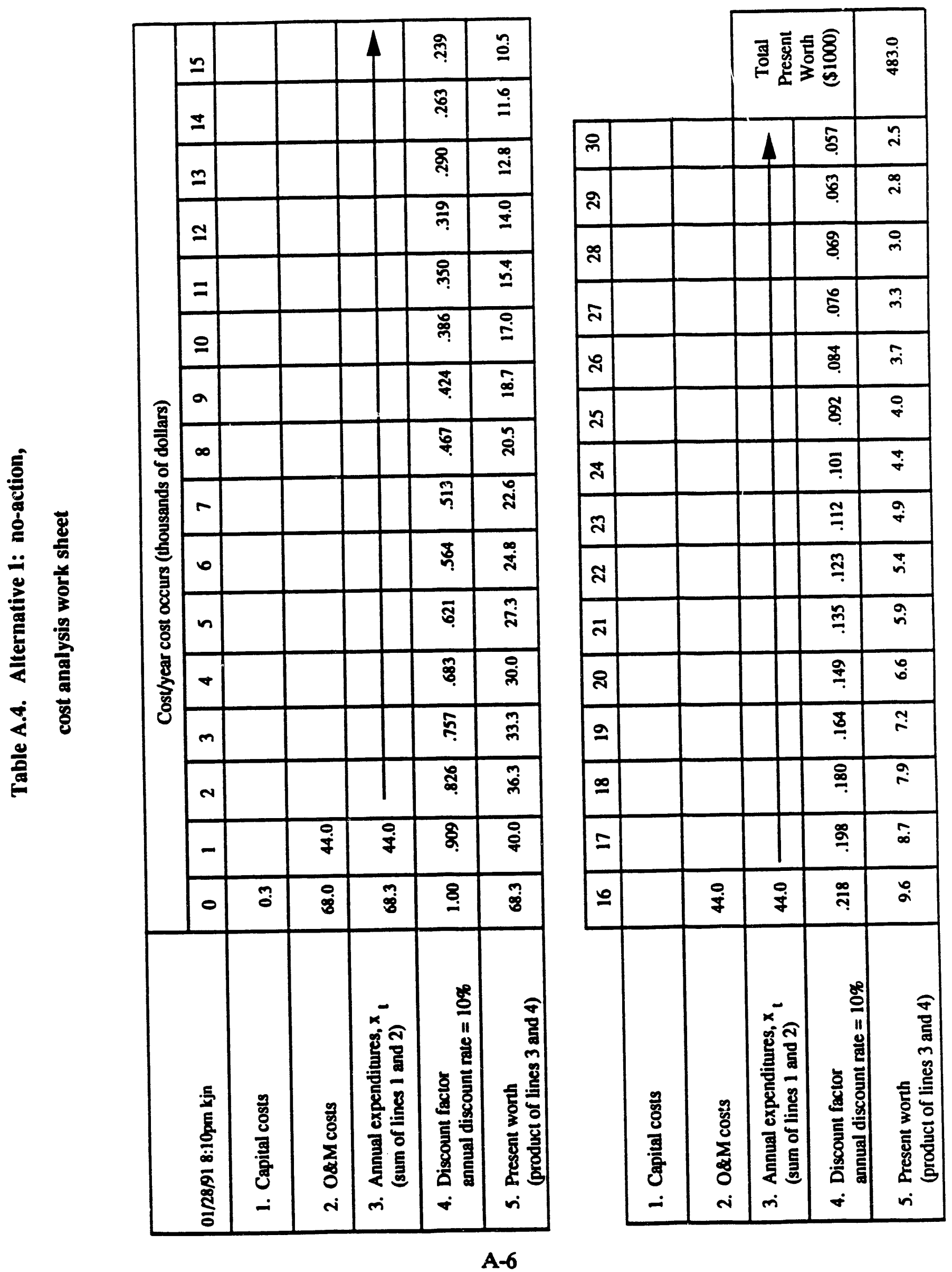
Table A.5. Alternative 1: no-action, sensitivity factors

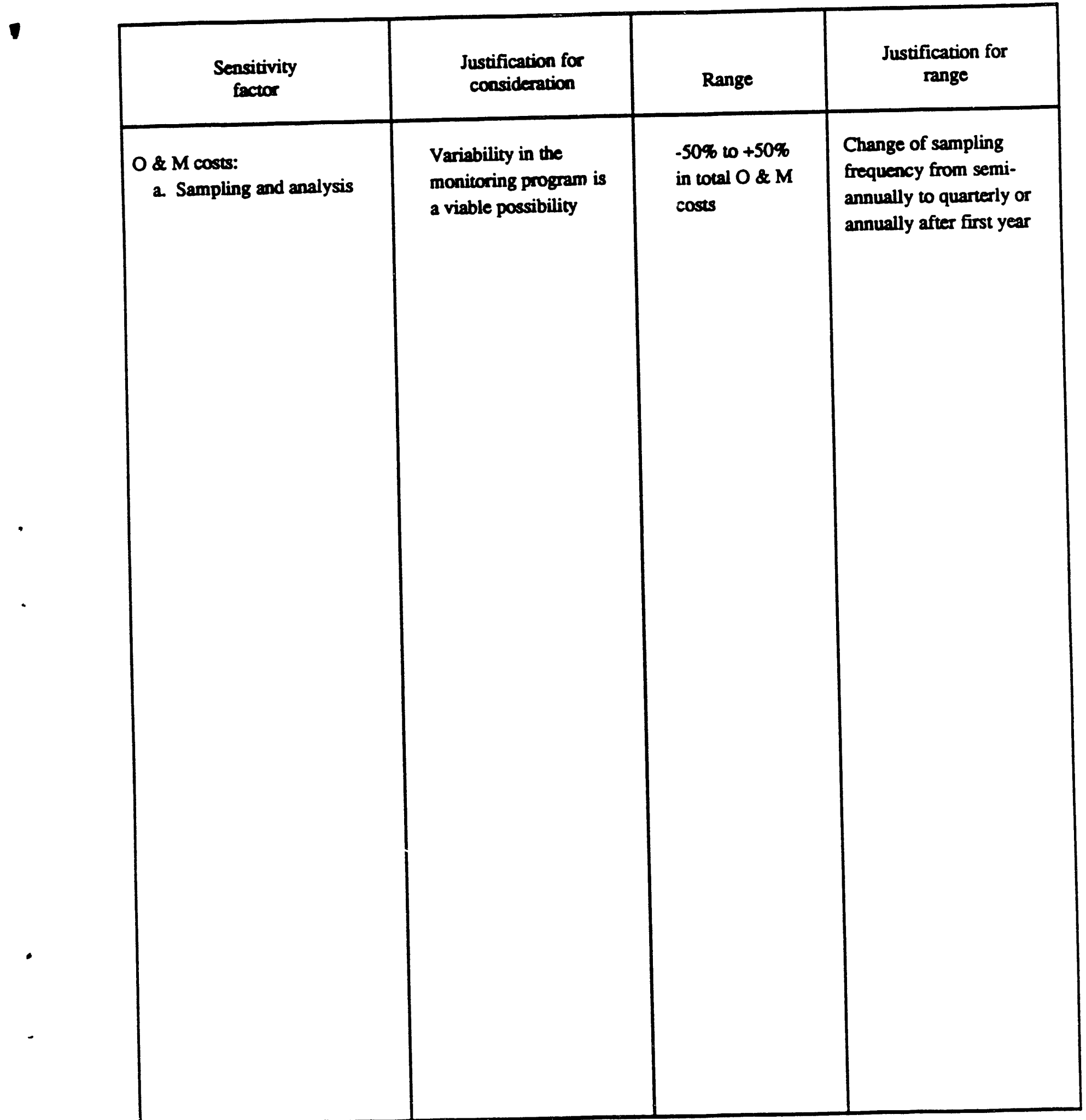


Table A.6. Alternative 1: no-action, summary of sensitivity analysis

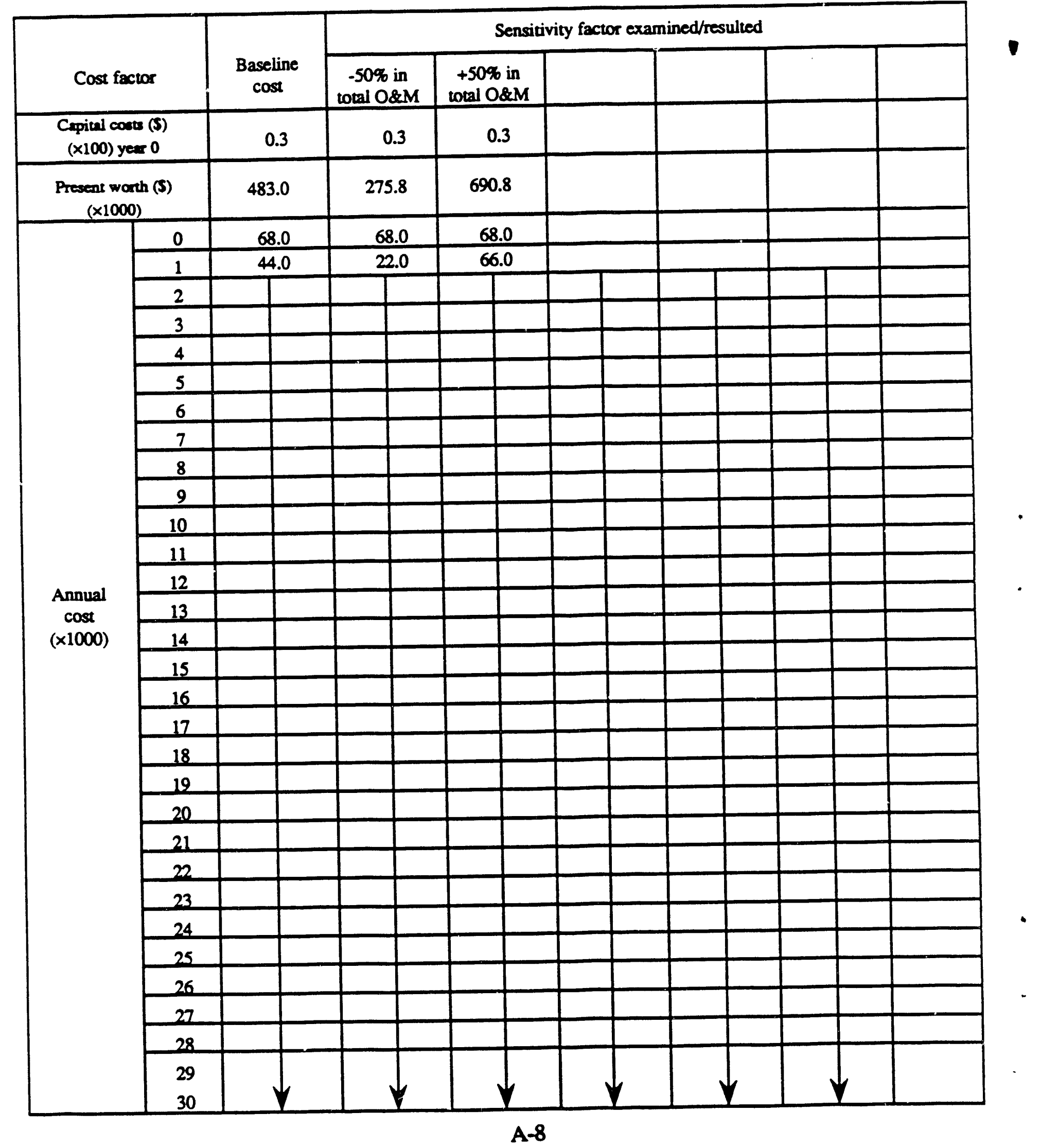


Table A.7. Alternative 2: modified RCRA cap,

capital cost

\begin{tabular}{|c|c|c|c|}
\hline \begin{tabular}{l}
\multicolumn{1}{c}{$\begin{array}{c}\text { Cost } \\
\text { component }\end{array}$} \\
Direct capital costs \\
1. Construction costs \\
a. Equipment \\
b. Labor \\
c. Materials \\
2. Equipment \\
a. Installed \\
b. Purchased \\
3. Site development \\
a. Equipment \\
b. Labor \\
c. Materials \\
4. Buildings and services \\
a. Equipment \\
b. Labor \\
c. Morerials \\
5. Disposa costs \\
TOTAL DIRECT COSTS
\end{tabular} & $\begin{array}{c}\text { Cost } \\
\text { estimate }\end{array}$ & $\begin{array}{l}\text { Basis of } \\
\text { estimate }\end{array}$ & $\begin{array}{l}\text { Year } \\
\text { incurred }\end{array}$ \\
\hline \multirow{6}{*}{$\begin{array}{l}\text { Direct capital costs } \\
\text { 1. Construction costs } \\
\text { a. Equipment } \\
\text { b. Labor } \\
\text { c. Materials } \\
\text { 2. Equipment } \\
\text { a. Installed } \\
\text { b. Purchased } \\
\text { 3. Site development } \\
\text { a. Equipment } \\
\text { b. Labor } \\
\text { c. Materials } \\
\text { 4. Buildings and services } \\
\text { a. Equipment } \\
\text { b. Labor } \\
\text { c. Morerials } \\
\text { 5. Disposa costs } \\
\text { TOTAL DIRECT COSTS }\end{array}$} & $\$ 176,200$ & \multirow[t]{2}{*}{ With material, RCRA cap (in place) } & \multirow[t]{2}{*}{0} \\
\hline & & & \\
\hline & $\$ 324,050$ & $\begin{array}{l}\text { SITE PREPARATION: Limestone sand fill and } \\
\text { clay fill (graded and compacted) }\end{array}$ & 0 \\
\hline & & Not applicable & \\
\hline & & Not applicable & \\
\hline & $\$ 500,250$ & & 0 \\
\hline \multirow{3}{*}{$\begin{array}{l}\text { Indirect capital costs } \\
\text { 1. Engineering and design } \\
\text { 2. Contingency } \\
\text { 3. Other indirect } \\
\text { a. Legal fees } \\
\text { b. License/permit } \\
\text { c. Start-up }\end{array}$} & $\$ 125,100$ & $25 \%$ of total direct cost* & \multirow{2}{*}{$\frac{0}{0}$} \\
\hline & $\$ 155,100$ & $31 \%$ of total direct cost* & \\
\hline & & & \\
\hline \multirow{2}{*}{$\begin{array}{l}\text { TOTAL INDIRECT COSTS } \\
\text { TOTAL CAPITAL COSTS }\end{array}$} & $\$ 284,200$ & & 0 \\
\hline & $\$ 780,500$ & & 0 \\
\hline
\end{tabular}

*Reference: Energy Systems. 
Table A.8. Altemative 2: modified RCRA cap, basis of direct cost estimate*

COST ITEM: Direct Construction Costs

COST COMPONENT:

Eauinmenthabbor.\&

BASIS: Minimum modififed RCRA Cap Design

CALCULATION/SOURCE:

\begin{tabular}{|c|c|c|c|}
\hline Description & Quantity & Unit price & $\begin{array}{l}\text { Total } \\
\text { costs }\end{array}$ \\
\hline \multicolumn{4}{|l|}{ A. CAPITAL COSTS } \\
\hline \multicolumn{4}{|l|}{ L. Sire preparation } \\
\hline \multicolumn{4}{|l|}{ a. Clearing \& grubbing } \\
\hline 1. East borrow area & $2,900 \mathrm{cy}$ & so.77/cy & $\$ 2,300$ \\
\hline 2. Landfill cap area & $1,800 \mathrm{cy}$ & $\$ 1.45 / c y$ & $\$ 2,600$ \\
\hline b. Excavation of east & $11,250 \mathrm{cy}$ & S7.46/cy & $\$ 84,000$ \\
\hline \multicolumn{4}{|l|}{ Borrow area } \\
\hline c. Limestone sand fill & $5,100 \mathrm{cy}$ & $\$ 25 / c y$ & $\$ 127,500$ \\
\hline d. Clay fill & $16,600 \mathrm{cy}$ & $54.56 / \mathrm{cy}$ & $\$ 75,700$ \\
\hline \multicolumn{4}{|l|}{ e. Erosion control } \\
\hline 1. Drainage ditches & $650 \mathrm{LF}$ & S3.47/LF & $\$ 2,300$ \\
\hline 2. Fescue sod & $2,600 \mathrm{SF}$ & S520/MSF & $\$ 1,350$ \\
\hline 3. Silt fence & $2,100 \mathrm{LF}$ & S3.00/LF & $\$ 6,300$ \\
\hline f. QA/QC testing & $\begin{array}{r}\text { Assume } 100 \\
\text { days }\end{array}$ & \$220/day & $\$ 22,000$ \\
\hline Site prep costs total & & & $\$ 324,050$ \\
\hline \multicolumn{4}{|l|}{ 2. Modified RCRA can } \\
\hline a. 30 mil HDPE liner & $55,200 \mathrm{SF}$ & SO.85/SF & $\$ 46,900$ \\
\hline b. Planar fluid flow mat & $55,200 \mathrm{SF}$ & S0.40/SF & $\$ 22,100$ \\
\hline c. Geotextile fabric & $55,850 \mathrm{SF}$ & SO.15/SF & $\$ 8,400$ \\
\hline d. Loam & $3,100 \mathrm{cy}$ & $\$ 12.70 / c y$ & $\$ 39,500$ \\
\hline e 6" PE pipe & $230 \mathrm{LF}$ & \$7.75/LF & $\$ 1,800$ \\
\hline \multicolumn{4}{|l|}{ 3. East borrow area } \\
\hline a. Loam & $4,300 \mathrm{cy}$ & \$12.70/CY & $\$ 55,000$ \\
\hline b. Hydro-seeding & $77,200 \mathrm{SF}$ & S32.70/MSF & $\$ 2,500$ \\
\hline TOTAL MODIFIED RCRA CAP COSTS & & & $\$ 176,200$ \\
\hline TOTAL DIRECT COSTS & & & $\$ 500,250$ \\
\hline
\end{tabular}

*All costs include labor. 
Table A.8. (continued)

\section{COST ITEM: Direct Construction Costs}

COST COMPONENT:

Eauioment.Labor. \&

BASIS: Minimum modified RCRA Cap Design

CALCULATION/SOURCE: SOURCES: Means Site Work Cost Data, 8th Annual Edition, 1989

Gundle Lining Inc., Personal Correspondence, 1990

Martin Matietta Energy Systems, Personal Communication, 1989 
Table A.9. Alternative 2: modified RCRA cap, annual operating costs





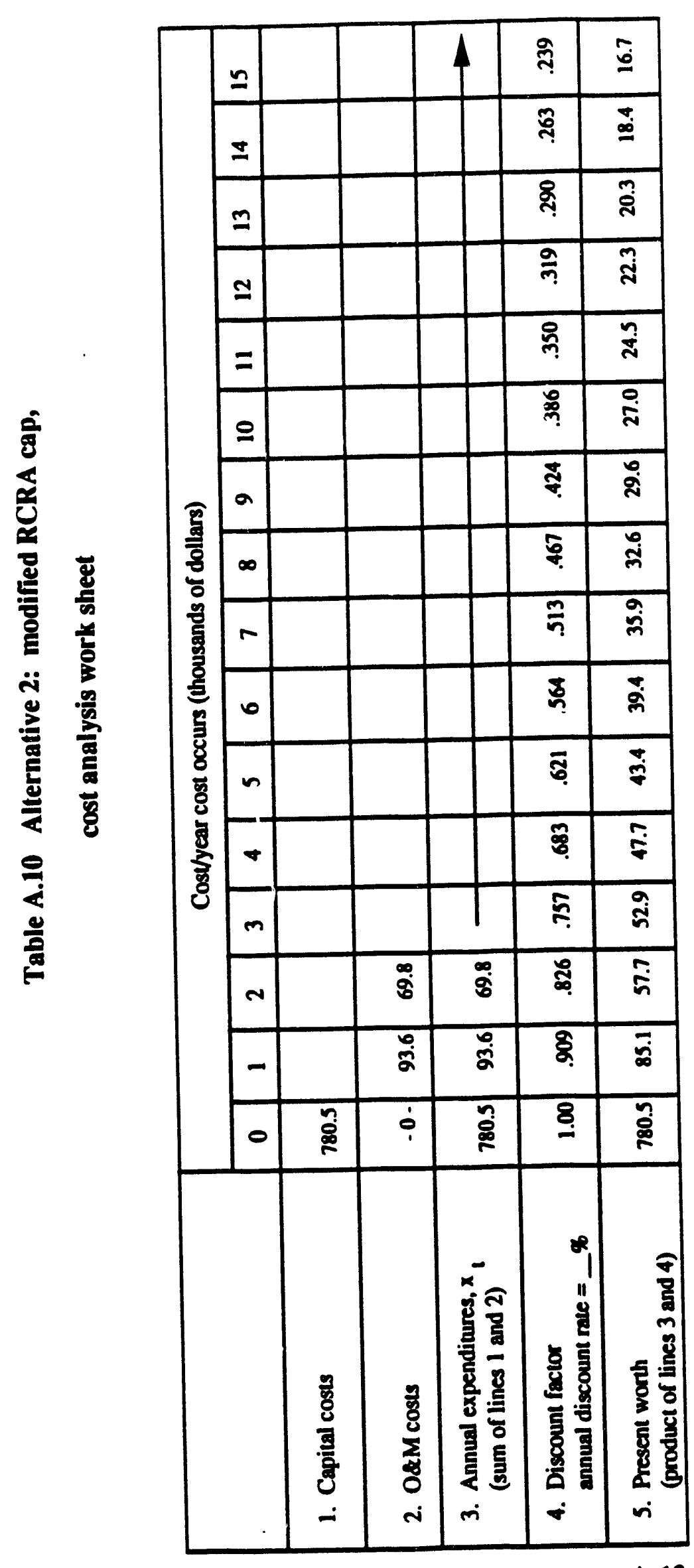

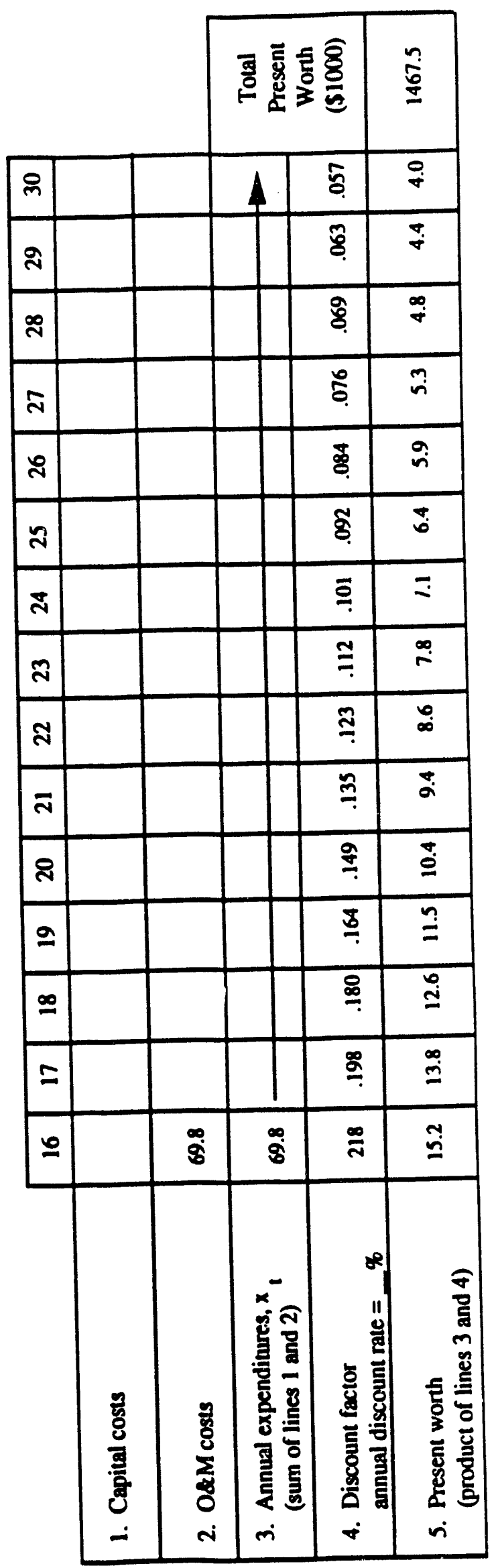


Table A.11. Altemative 2: modified RCRA cap, sensitivity factors

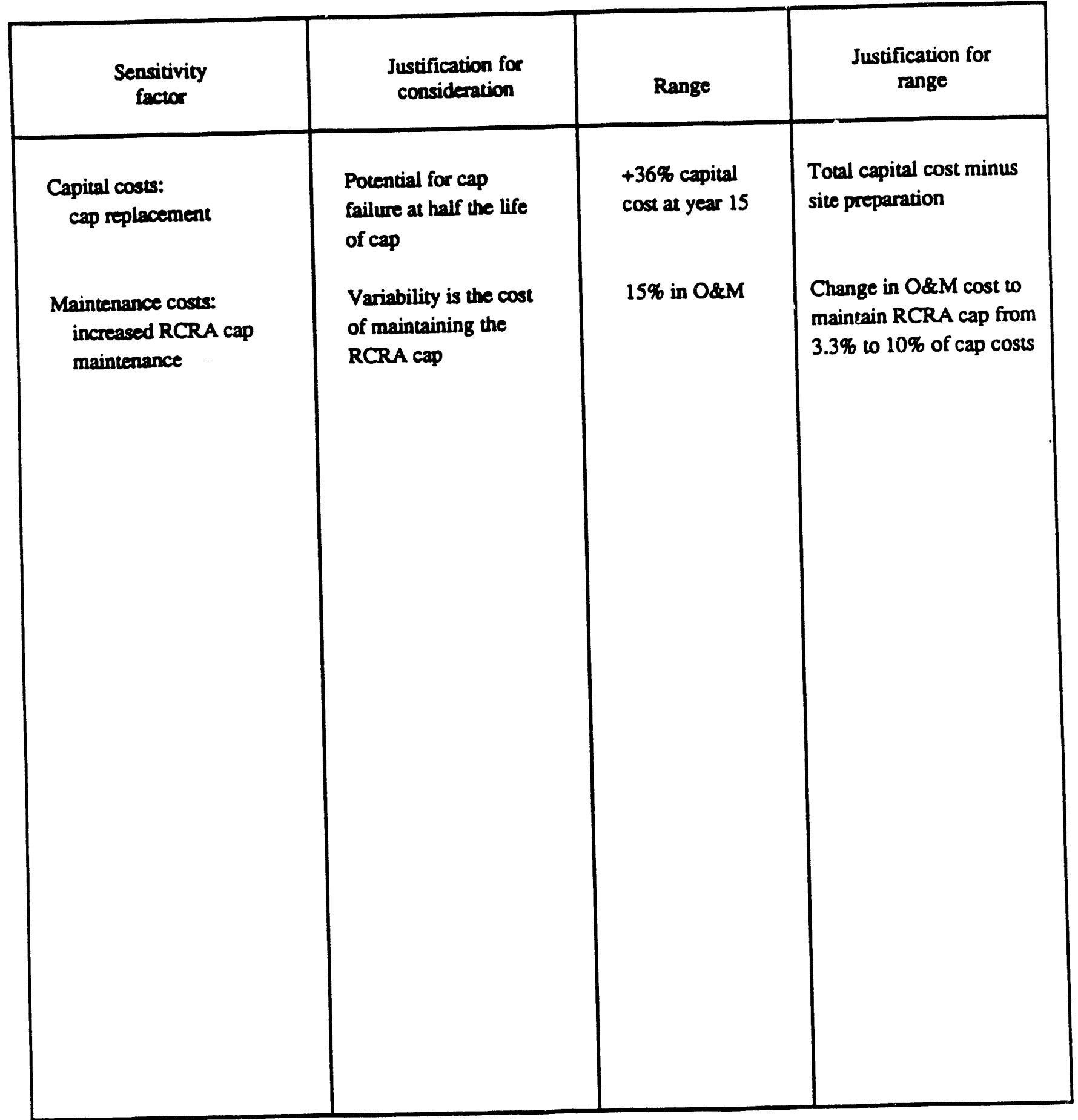


Table A.12. Alternative 2: modified RCRA cap, summary of sensitivity analysis

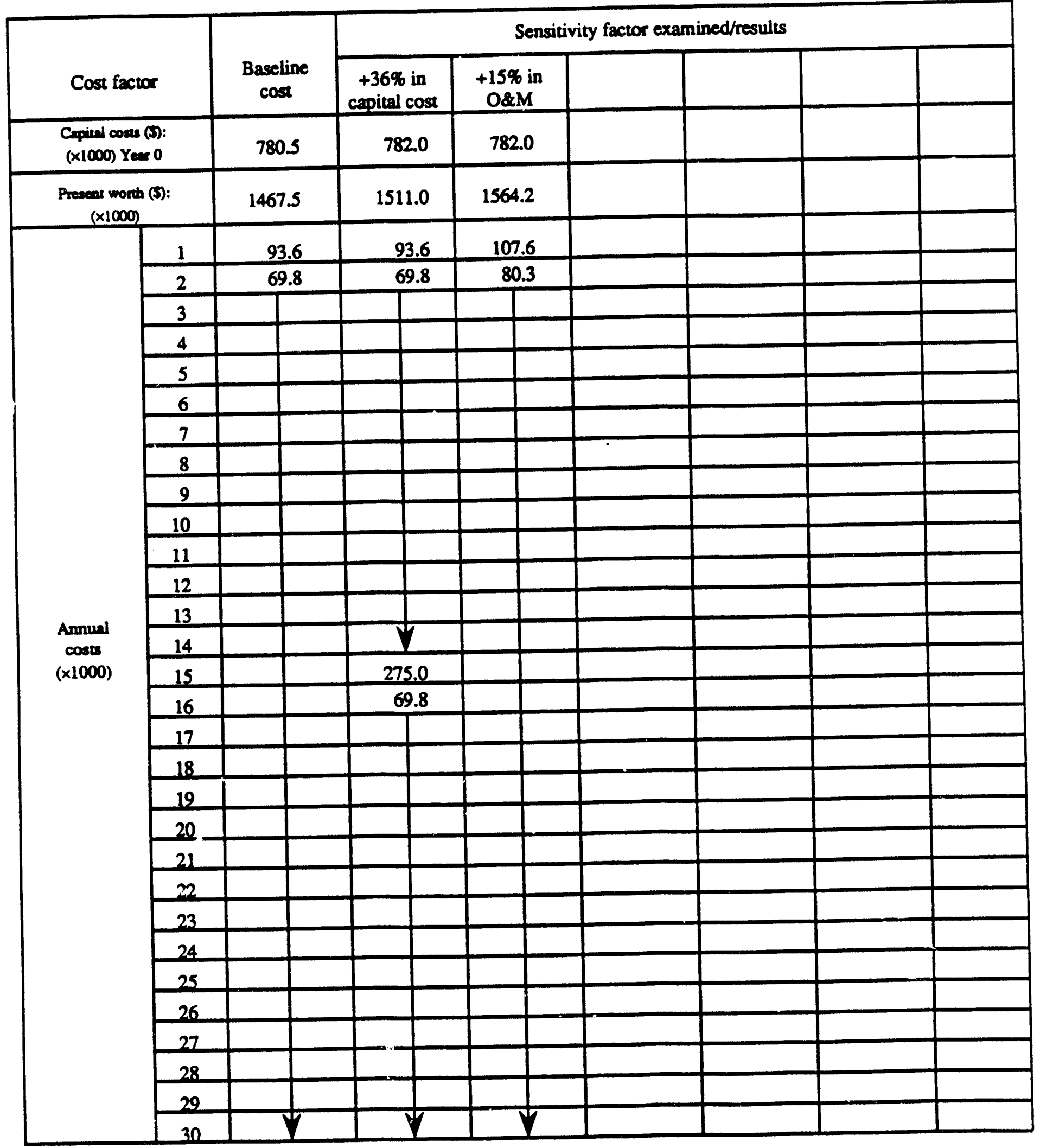


Table A.13. Alternative 3: treatment and capping,

capital cost

\begin{tabular}{|c|c|c|c|}
\hline $\begin{array}{c}\text { Cost } \\
\text { component }\end{array}$ & $\begin{array}{c}\text { Cost } \\
\text { estimate }\end{array}$ & $\begin{array}{l}\text { Basis of } \\
\text { estimate }\end{array}$ & $\begin{array}{c}\text { Year } \\
\text { incurred }\end{array}$ \\
\hline \multicolumn{4}{|l|}{$\begin{array}{l}\text { Direct capital costs } \\
\text { 1. Construction costs } \\
\text { a. Equipment } \\
\text { b. Labor } \\
\text { c. Materials }\end{array}$} \\
\hline \multicolumn{4}{|l|}{$\begin{array}{l}\text { 2. Equipment costs } \\
\text { Installed } \\
\text { Purchased }\end{array}$} \\
\hline \multirow{2}{*}{$\begin{array}{l}\text { 3. Land and site development } \\
\text { a. Equipment } \\
\text { b. Labor } \\
\text { c. Materials } \\
\text { Subtogl }\end{array}$} & 324,050 & \multirow[t]{2}{*}{$\begin{array}{l}\text { Site preparation for } \\
\text { capping only: limestone } \\
\text { sand fill and clay fill }\end{array}$} & \multirow[t]{2}{*}{0} \\
\hline & 324,050 & & \\
\hline \multicolumn{4}{|l|}{$\begin{array}{l}\text { 4. Buildings and services } \\
\text { a. Equipment } \\
\text { b. Labor } \\
\text { c. Materials }\end{array}$} \\
\hline \multicolumn{4}{|l|}{$\begin{array}{l}\text { Subtotal } \\
\text { 5. Relocation costs } \\
\text { Subtotal }\end{array}$} \\
\hline \multicolumn{4}{|l|}{ 6. Disposal costs } \\
\hline & $1,506,500$ & & 0 \\
\hline \multirow{4}{*}{$\begin{array}{l}\text { Indirect capital costs } \\
\text { 1. Engineering and design } \\
\text { 2. Contingency allowance } \\
\text { 3. Other indirect costs } \\
\text { a. Legal fees } \\
\text { b. License/permit costs } \\
\text { c. Start-up and shake-down } \\
\text { Subtotal } \\
\text { TOTAL INDIRECT COSTS }\end{array}$} & 376,600 & $25 \%$ of total direct cost & 0 \\
\hline & 467,000 & $31 \%$ of total direct cost & 0 \\
\hline & 3000 & & 0 \\
\hline & 846,600 & & 0 \\
\hline TOTAL CAPITAL COSTS & $2,353,100$ & & 0 \\
\hline
\end{tabular}

"Reference: Energy Systems. 
Table A.14. Alternative 3: treatment and capping, basis of capital cost estimate

COST IIEM: Direct Construction Costs

COST COMPONENT: Equinement Labor, and Materials

BASIS: Treatment consises of solid waste processing

equeous waste treatment and a modified RCRA cap

CALCULATIONSOURCE:

Solid waste precessing

\begin{tabular}{|c|c|c|c|}
\hline & Labor & Equipment & Towal \\
\hline $\begin{array}{l}\text { Excavaur for concrete pulvizer } 80 \\
\text { CP } 80 \text { arm } \\
\text { Front beder } \\
\text { Excavator for drum grappling arm } \\
\text { Drum grappling arm } \\
\text { Secondary crusher + setup } \\
\text { Metal stredder }\end{array}$ & $\begin{array}{l}575.00 \mathrm{mr} \\
550.00 \mathrm{mr} \\
555.00 \mathrm{mr} \\
\$ 40.00\end{array}$ & $\begin{array}{l}\text { inciuded } \\
\$ 31,000 \\
\text { included } \\
\text { included } \\
\$ 21,900 \\
\text { included + } \$ 21,500 \\
\$ 23,450\end{array}$ & $\begin{array}{r}\mathbf{s} 17, \mathbf{S 0 0} \\
\mathbf{\$ 3 1 , 0 0 0} \\
\mathbf{\$ 1 4 5 , 0 0 0} \\
\mathbf{\$ 1 5 9 , 5 0 0} \\
\mathbf{\$ 2 1 , 9 0 0} \\
\mathbf{\$ 1 3 7 , 5 0 0} \\
\mathbf{\$ 2 5 , 5 0 0}\end{array}$ \\
\hline & & & $\$ 737,900$ \\
\hline \multicolumn{4}{|c|}{ Solid waste leaching and wastewater trestment } \\
\hline & Labor & Equipment & Toul cost \\
\hline $\begin{array}{l}\text { Soil washing and wastewater treament } \\
\text { Treambility swdy } \\
\text { Equalization rank, } 10,000 \mathrm{gal}\end{array}$ & $\begin{array}{r}\$ 60.00 / 10 n \\
\$ 20,000\end{array}$ & $\begin{array}{l}\text { included } \\
\text { included } \\
1000 / \text { month }\end{array}$ & $\begin{array}{r}\$ 232,300 \\
\$ 20,000 \\
\$ 16,000\end{array}$ \\
\hline & & & $\$ 268,300$ \\
\hline \multicolumn{4}{|l|}{ RCRA-type cap } \\
\hline & & & Total cost \\
\hline $\begin{array}{l}\text { Construction cost } \\
\text { Site preparation }\end{array}$ & $\begin{array}{l}1-A 2-2 \text { for } \\
1-A 2-4 \text { for }\end{array}$ & $\begin{array}{l}\text { il } \cos x \\
\text { il } \cos x\end{array}$ & $\begin{array}{l}\$ 176,200 \\
\$ 324,050\end{array}$ \\
\hline
\end{tabular}


Table A.14. (continued)

COST ITEM:

\section{COST COMPONENT:}

BASIS: Treatment consists of solid waste urocessing aqueous waste reatment and a RCRA-tyoe can

CALCULATION/SOURCE: SOURCES: La Bounty Manufacturing, Inc., Petsonal Communication, 1989

B\&D Equipment Co. Personal Communication, 1989

D\&G Excavating Co., Personal Communication, 1989

Martin Mariecta Energy Systems, Personal

Communication. 1989 
Table A.15. Alternative 3: treatment and capping, annual operating costs

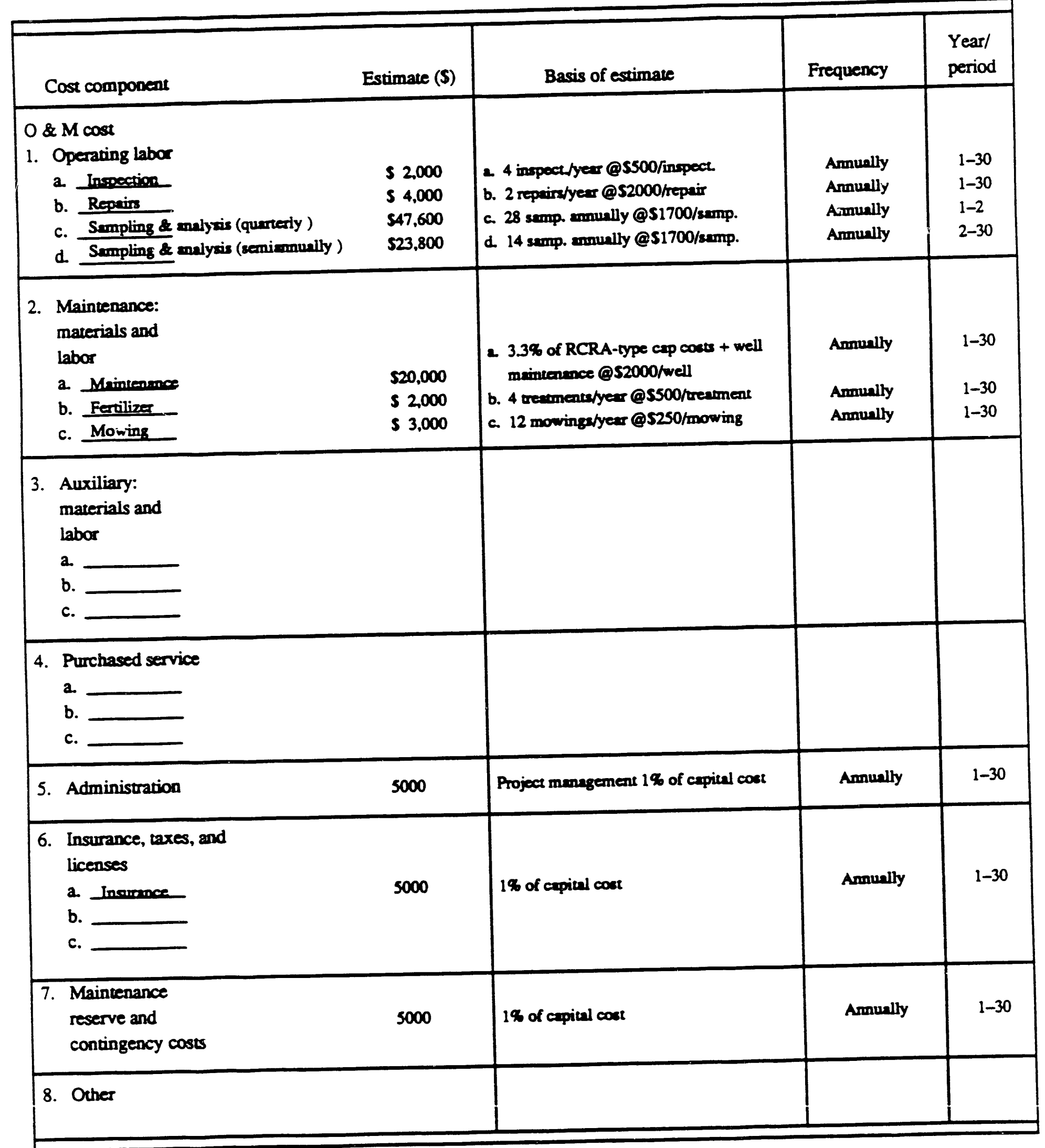




Table A.17. Alternative 3: treatment and capping,

sensitivity factors

\begin{tabular}{|c|c|c|c|}
\hline $\begin{array}{l}\text { Senzitivity } \\
\text { facior }\end{array}$ & $\begin{array}{l}\text { Justification for } \\
\text { consideration }\end{array}$ & Range & $\begin{array}{l}\text { Justification for } \\
\text { range }\end{array}$ \\
\hline $\begin{array}{l}\text { Capital cos's: } \\
\text { slytifs dreatment }\end{array}$ & $\begin{array}{l}\text { Variability in the cost } \\
\text { of treating sludge is a } \\
\text { viable possibility }\end{array}$ & $\begin{array}{l}-8 \% \text { to }+12 \% \text { in } \\
\text { capital costs }\end{array}$ & $\begin{array}{l}\text { Change in cost to treat } \\
\text { each ton of sludge }-33 \% \\
\text { to }+40 \%\end{array}$ \\
\hline
\end{tabular}


Table A.18. Alternative 3: treatment and capping, summary of sensitivity analysis

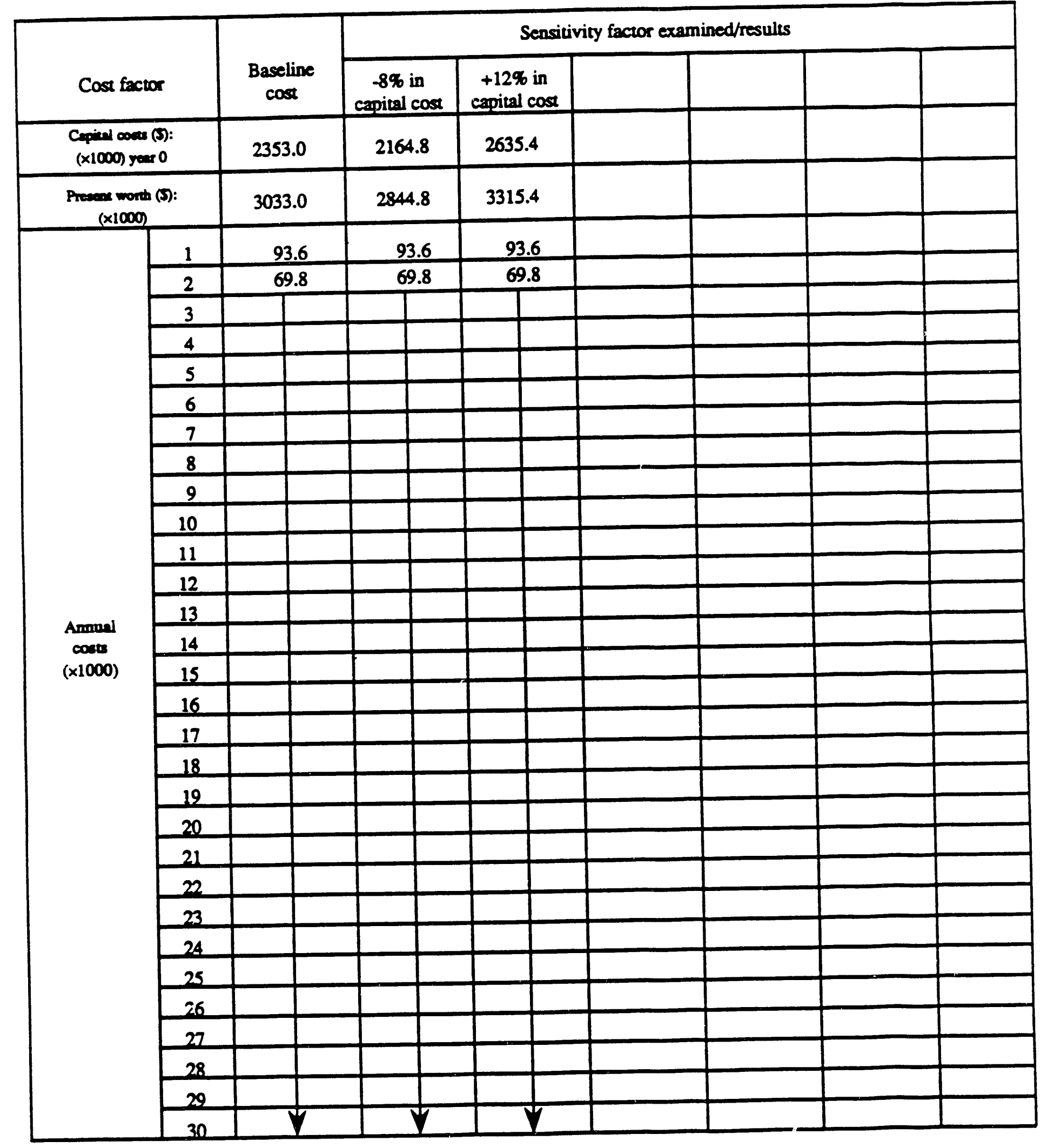


Table A.19. Alternative 4: off-site disposal, capital cost

\begin{tabular}{|c|c|c|c|}
\hline $\begin{array}{c}\text { Cost } \\
\text { component }\end{array}$ & $\underset{\text { estimate }}{\text { Cost }}$ & $\begin{array}{l}\text { Basis of } \\
\text { estimate }\end{array}$ & $\begin{array}{l}\text { Year } \\
\text { incurred }\end{array}$ \\
\hline \multirow{4}{*}{$\begin{array}{l}\text { Direct capital costs } \\
\text { 1. Construction costs } \\
\text { a. Equipment } \\
\text { b. Labor } \\
\text { c. Materiais } \\
\text { d. Soil Analysis } \\
\text { Subtotal } \\
\text { 2. Equipment costs } \\
\text { 3. Land and site development } \\
\text { a. Equipment } \\
\text { b. Labor } \\
\text { c. Materials }\end{array}$} & $\begin{array}{r}22,000 \\
120,000 \\
3,410,000 \\
24,000 \\
\end{array}$ & $\begin{array}{l}\text { Drum grappler } \\
4 \text { ground crew at } 3100 \mathrm{hrs} \\
\text { Overpacks }(30,800) \\
\text { Site closure }\end{array}$ & $\begin{array}{l}0 \\
0 \\
0\end{array}$ \\
\hline & $3,576,000$ & \multirow[b]{2}{*}{ Excavator/forklift } & \\
\hline & 205,000 & & \\
\hline & $-0-$ & 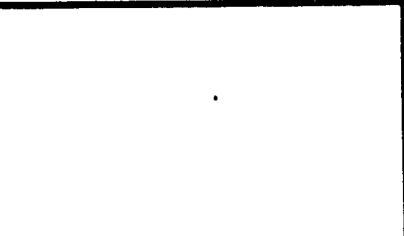 & 0 \\
\hline \multirow{4}{*}{$\begin{array}{l}\text { 4. Buildings and services } \\
\text { a. Equipment } \\
\text { b. Labor } \\
\text { c. Materials Subtotal } \\
\text { 5. Relocation costs } \\
\text { Subtotal } \\
\text { 6. Disposal costs Subtotal } \\
\text { TOTAL DIRECT COSTS }\end{array}$} & $3,100,000$ & $\begin{array}{l}\text { Hauling contractor for } \\
30,800 \text { overpacks to } \\
\text { Nevada ( } 2100 \mathrm{mi})\end{array}$ & 0 \\
\hline & & & \\
\hline & $\begin{array}{l}1,950,000 \\
1,950,000\end{array}$ & $\begin{array}{l}\$ 150.00 / \text { ton at disposal } \\
\text { facility }\end{array}$ & 0 \\
\hline & $8,831,000$ & & $\overline{0}$ \\
\hline \multirow{4}{*}{$\begin{array}{l}\text { Indirect capital costs } \\
\text { 1. Engineering and design } \\
\text { 2. Contingency allowance } \\
\text { 3. Other indirect costs } \\
\text { a. License/permit costs } \\
\text { b. Administration } \\
\text { Subtotal } \\
\text { TOTAL INDIRECT COSTS }\end{array}$} & $2,208,000$ & $25 \% *$ of direct costs & 0 \\
\hline & $2.738,000$ & $31 \% *$ of direct costs & 0 \\
\hline & $\begin{array}{r}-0- \\
177,000 \\
\end{array}$ & $\begin{array}{l}\text { Negligible } \\
2 \% \text { of direct costs }\end{array}$ & 0 \\
\hline & $\frac{171,000}{5,123,000}$ & & 0 \\
\hline TOTAL CAPITAL COSTS & $13,954,000$ & & 0 \\
\hline
\end{tabular}

-Reference: Energy Systems. 
Table A.20. Alternative 4: off-site disposal, basis of capital cost estimate

COST ITEM: Direct - Capital Costs

BASIS: Assume handling and overpack of 29,000 drums,

1,800 drums of misc. material: assume 80 overpacks

per truckload for travel distance of $2,100 \mathrm{mi}$.

CALCULATION/SOURCE: DRUMAMATERIALHANDIING AND PACKAGNG:

Doum Grampler and Conversion Ki

$=\$ 22.000$

Track-Mounted Excayator (incl opperator) at

$\$ 55.00 \mathrm{hr} / 8 \mathrm{hr}-\mathrm{day} / 365$ days $=\$ 1600000$

4 Ground arew at $\$ 9.63 \mathrm{hr} / 8 \mathrm{hr}$-dayl $=\$ 1200000$

Eordlift Rental \& Opecatine Costs $=S 450000$

Oxempactossteel 85-gallon 30.80 .0

at $\$ 10.6110 a$ $=\$ 3,270.000$

IRANSPORT COSTS:

Semi-muck S8000load/388 loads $-5310.00 .00$ 
Table A.20. (continued)

COST ITEM: Direct - Capital Costs

COST COMPONENT:

Equip.. Labor, Material

BASIS: Assume disposal of 30,800 overpecks at

$850 \mathrm{lbs}$ each; site closure soil volume

assumed equal to excavation volume

CALCULATION/SOURCE: DISPOSALCOSTS:

Solid material at $5150.00 \mathrm{ion} / 13,0.00 \mathrm{tons}$

$=\$ 1950.000$

* SUIECCLOSURE. Excavare common soil from bormow area 3 CY front

loader haul 1 mile backfill compact $22.000 \mathrm{CY}$ at

$\$ 6.5310 \mathrm{CY}$ $=\$ 140.000$

ICLPSoil Analyarex Soil sampline of ercavation @ $50 \mathrm{fl} \times 50 \mathrm{ft}$ sampling gaid.

16 samples per sampline depth $\Omega$ gaund surface 5 and 10 ft helow depth

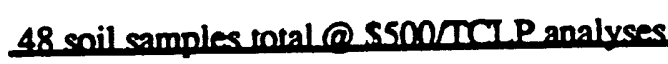

$=524000$

*50\% allocated to equipment and labor in capital cost summary.

A-25 
Table A.20. (continued)

COST ITEM: Direct - Capital Costs

COST COMPONENT:

BASIS:

CALCULATION/SOURCE: SOURCES; Vendor Cataloos/Ountes

Means Heavy Consmuction Cost Dara.

Sth Ed. 1990

SAIC. Personal Communication with

Martin Marienta Eneroy Systems. Inc. 1990 
Table A.21. Altemative 4: off-site disposal, annual operating costs

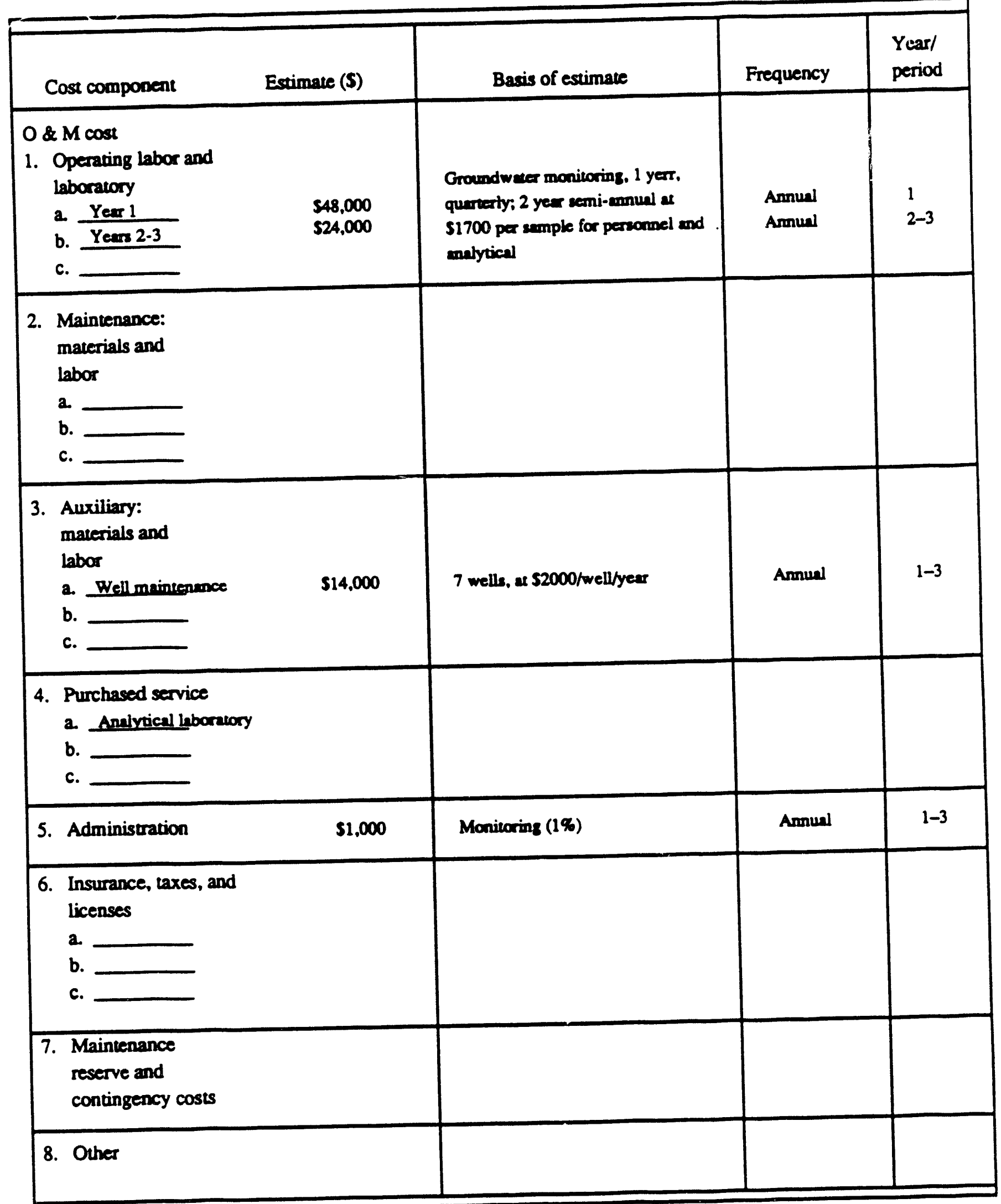



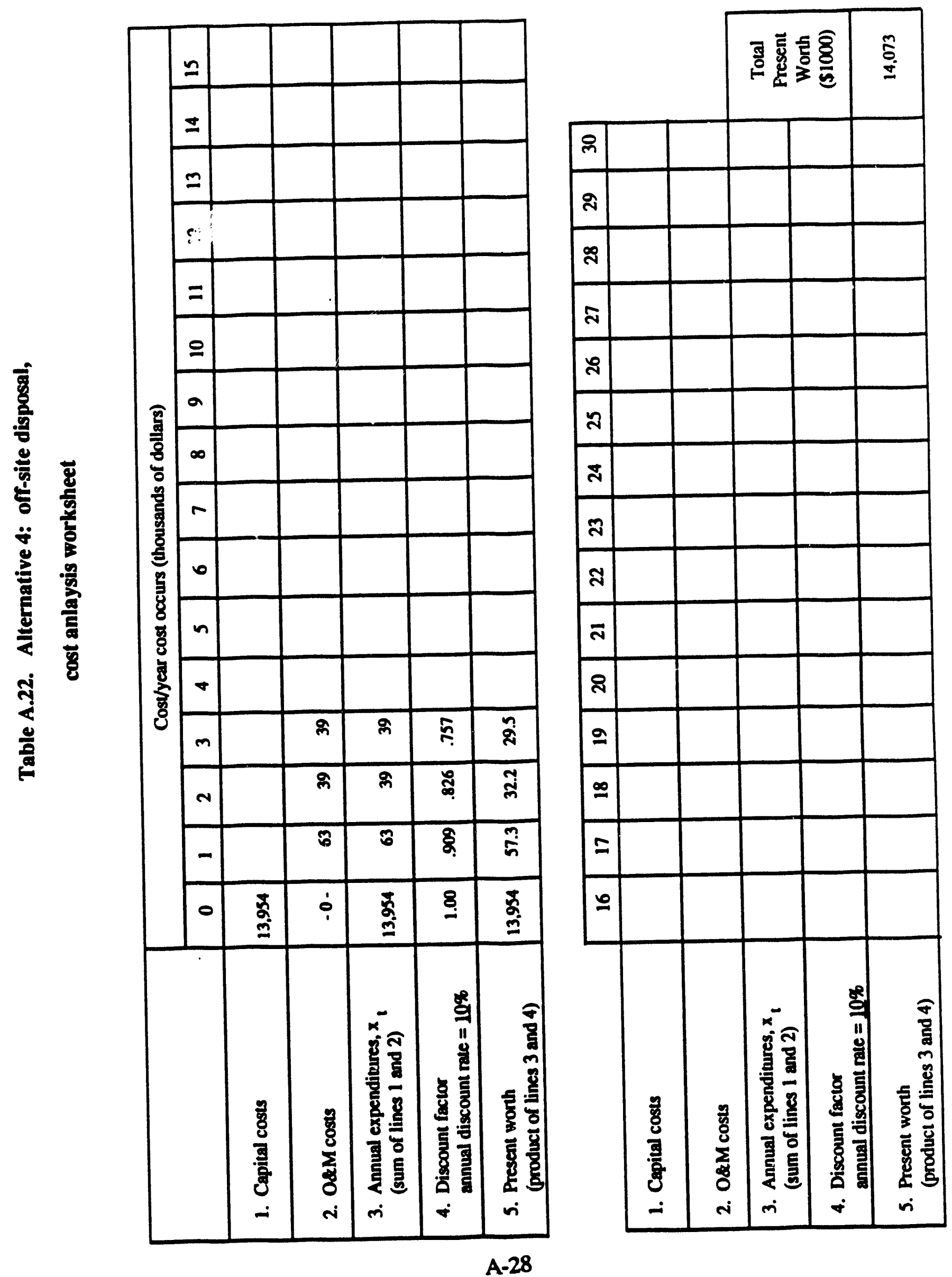
Table A.23. Alternative 4: off-site disposal, sensitivity factors

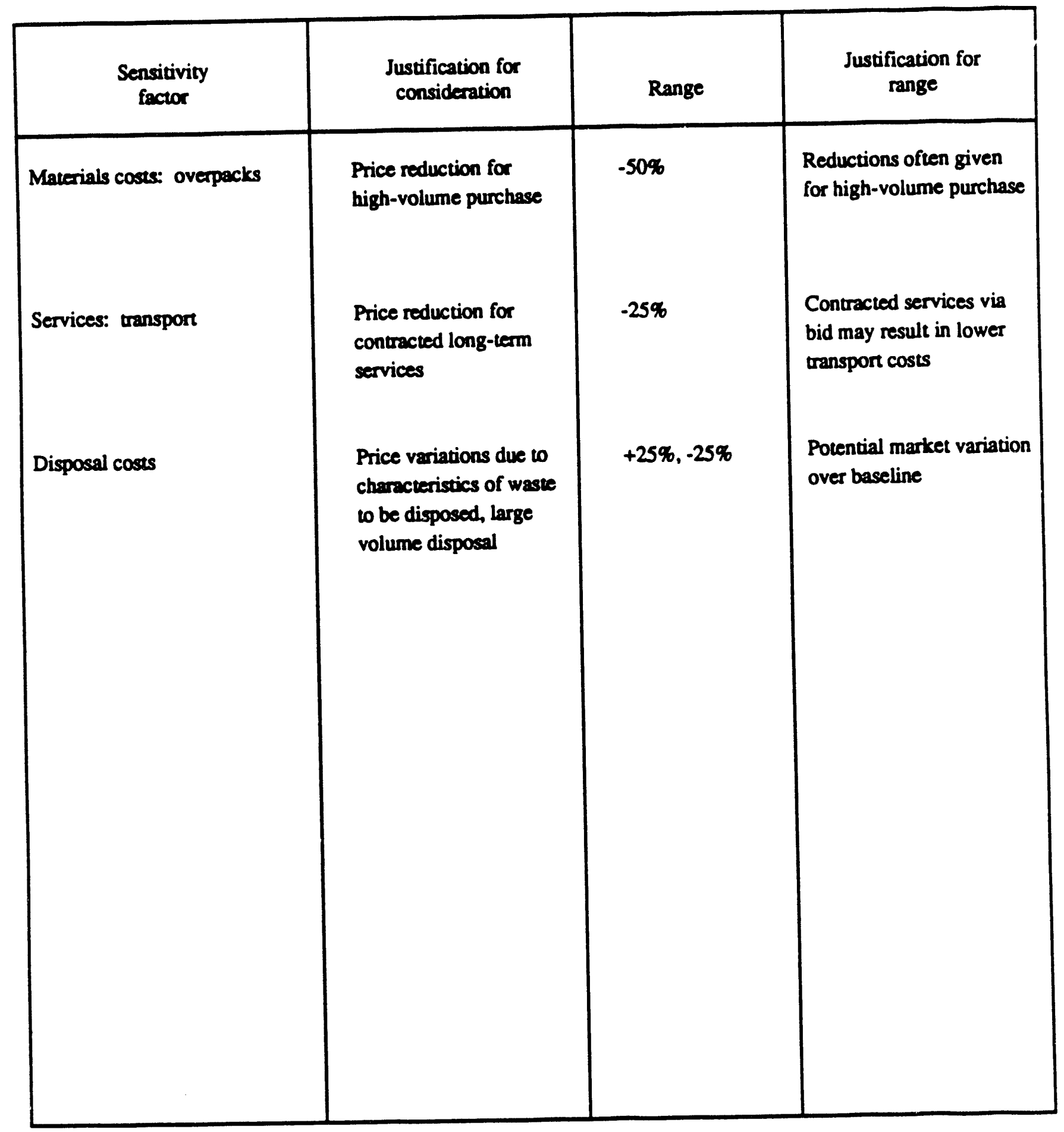


Table A.24. Alternative 4: off-site disposal, summary of sensitivity analysis

\begin{tabular}{|c|c|c|c|c|c|c|c|c|}
\hline \multirow{2}{*}{\multicolumn{2}{|c|}{$\operatorname{Cost}$ factor }} & \multirow{2}{*}{$\begin{array}{c}\text { Baseline } \\
\text { cost } \\
(\times 1000)\end{array}$} & \multicolumn{5}{|c|}{ Sensitivity factor examined/results } & \\
\hline & & & $\begin{array}{c}.50 \% \\
\text { materials }\end{array}$ & $\begin{array}{c}-25 \% \\
\text { transport }\end{array}$ & $\begin{array}{c}+25 \% \\
\text { disposal }\end{array}$ & $\begin{array}{c}-25 \% \\
\text { disposal }\end{array}$ & $\begin{array}{l}-50 \% \text { mal. } \\
-25 \% \text { trans. }\end{array}$ & \\
\hline \multicolumn{2}{|c|}{$\begin{array}{l}\text { Coppitul coeses (\$) } \\
(\times 1000) \text { year } 0\end{array}$} & 13,954 & 12,319 & 13,179 & 14,442 & 13,467 & 11,544 & \\
\hline \multicolumn{2}{|c|}{$\begin{array}{c}\text { Prevent worth (s) } \\
(\times 1000)\end{array}$} & 14,073 & 12,438 & 13,298 & 14,561 & 13.586 & 11,663 & \\
\hline \multirow{22}{*}{$\begin{array}{l}\text { Annual } \\
\text { expendiures } \\
\text { (\$/years } x \\
1,000)\end{array}$} & 1 & 63 & 63 & 63 & 63 & 63 & 63 & \\
\hline & 2 & 39 & 39 & 39 & 39 & 39 & 39 & \\
\hline & 3 & 39 & 39 & 39 & 39 & 39 & 39 & \\
\hline & & & & & & & & \\
\hline & & & & & & & & \\
\hline & & & & & & & & \\
\hline & & & & & & & & \\
\hline & & & & & & & & \\
\hline & & & & & & & & \\
\hline & & & & & & & & \\
\hline & & & & & & & & \\
\hline & & & & & & & & \\
\hline & & & & & & & & \\
\hline & & & & & & & & \\
\hline & & & & & & & & \\
\hline & & & & & & & & \\
\hline & & & & & & & & \\
\hline & & & & & & & & \\
\hline & & & & & & & & \\
\hline & & & & & & & & \\
\hline & & & & & & & & \\
\hline & & & & & & & & \\
\hline
\end{tabular}


ES/ER-15\&D1

\section{INTERNAL DISTRIBUTION}

1. L. D. Bates

2. J. K. Bailey

3. W. M. Belvin

4. D. J. Bostock

5. J. S. Colley

6. N. W. Durfee

7. J. E. Heiskell

8. R. M. Hill

9. D. D. Huff

10-11. J. E. Keyes

12. C. W. Kimbrough

13-15. R. T. Moore

16-19. L. L. Oakes
20-23. P. T. Owen

24. J. K Siberell

25. J. E. Stone

26. D. W. Swindle, Jr.

27. T. S. Tison

28. L. D. Voorhees

29. G. E. Ward

30. S. H. Welch

31. R. K. White

32. L. F. Willis

33-54. ER Document Management Center

55. Y-12 Plant Records

56. Y-12 Technical Library

\section{EXTERNAL DISTRIBUTION}

57-76. R. C. Sleeman, Department of Energy, Oak Ridge Operations, P.O. Box 2001, Oak Ridge, TN 37831-8540

77-78. P. H. Edmonds, Lee Wan and Associates, 120 S. Jefferson Circle, Oak Ridge, TN 37830

79-80. Kurt Oschman, Science Applications Internaltional Corporation, 800 Oak Ridge Turnpike, Oak Ridge, TN 37830 



$\exists$

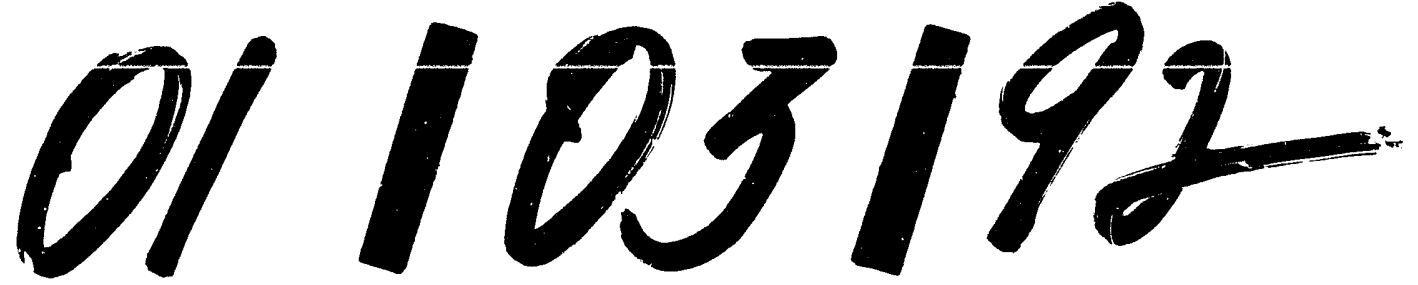


